J. Lyact AUSTRALA 1988

30 AuqustIS OCT NSW, $\varphi$ LD. 
38 Auco sT 1988

Eिactice Surveys cerq

- Eastum border of Duvehapé East 14:45 Parkat kagaroo rd, work 5. an

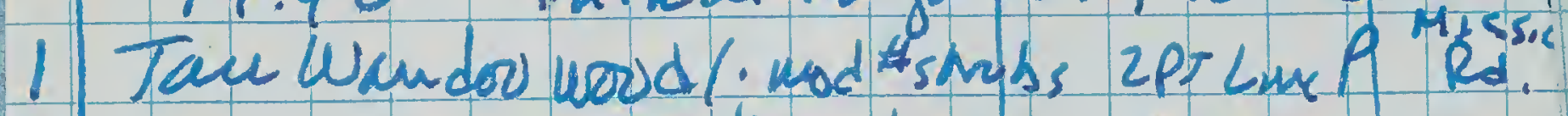

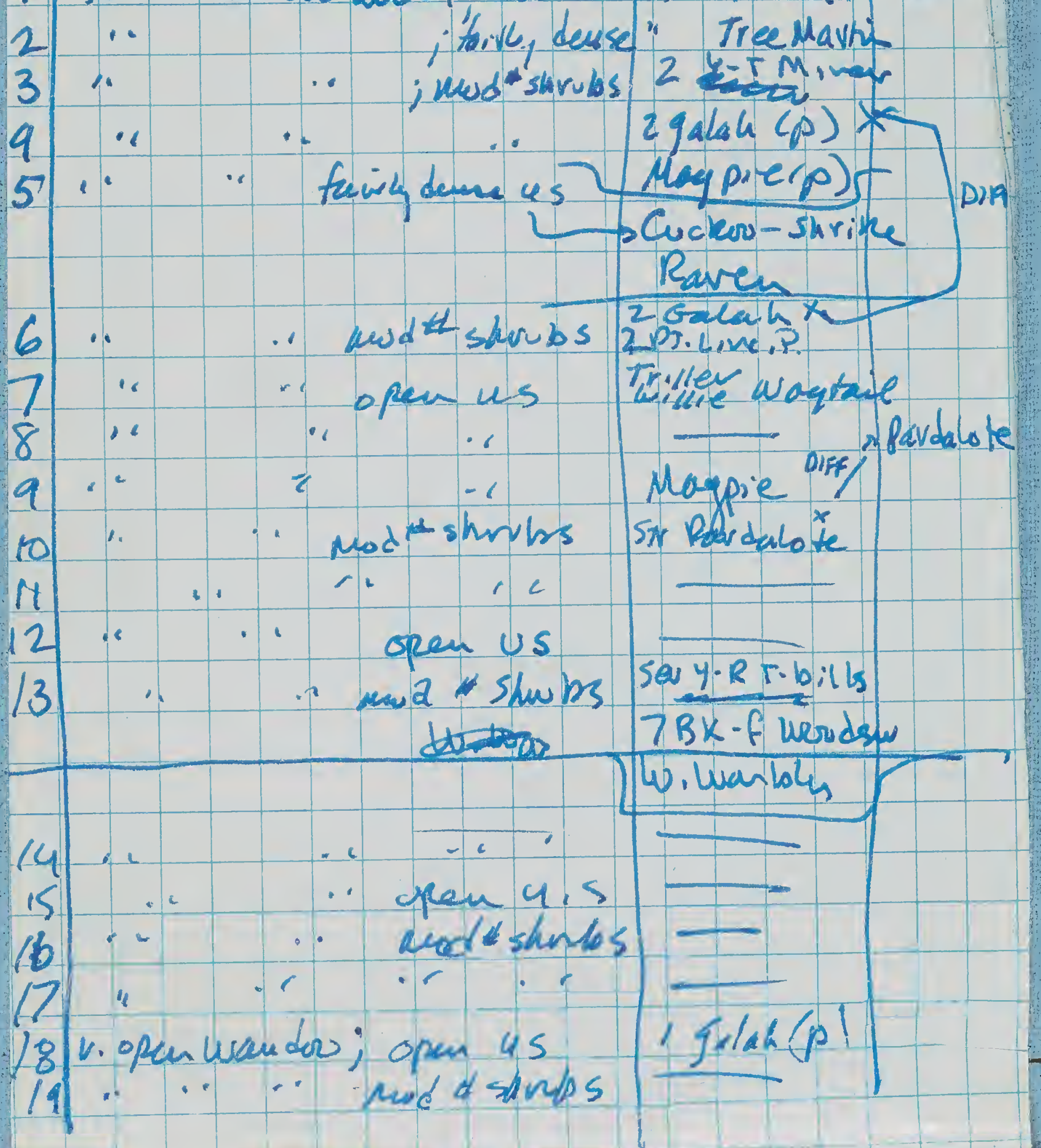

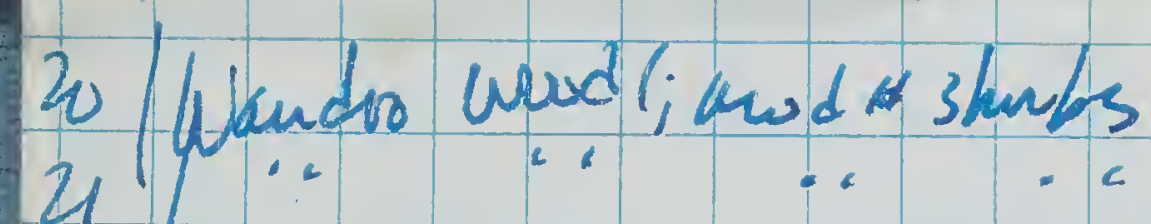

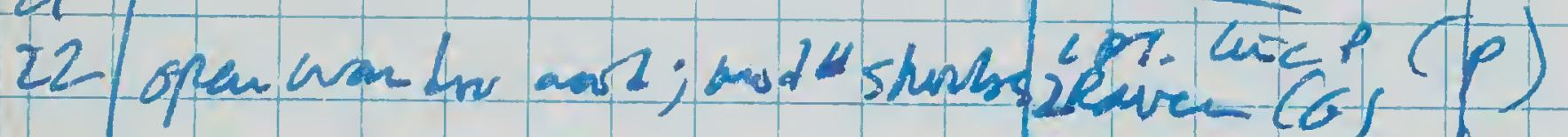

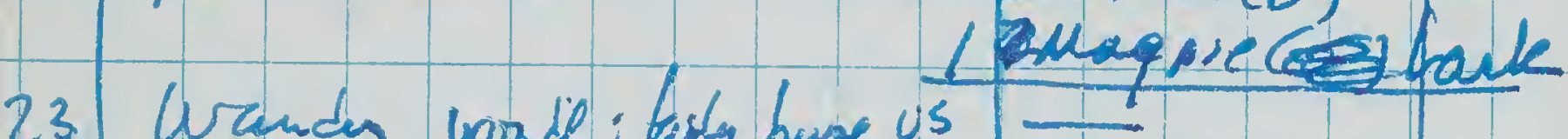

23 Wandar vorde ; tasty bure us

24

san weebills

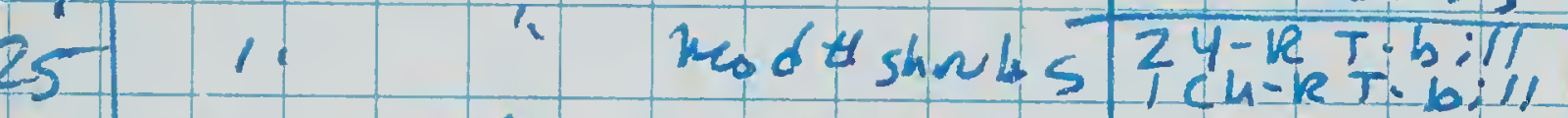

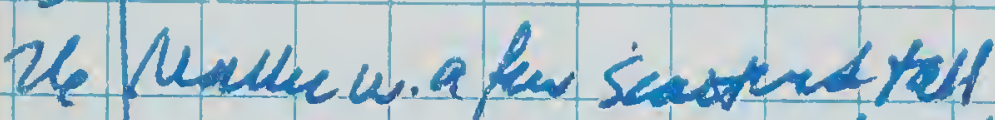
wandor, nod shulas

M. Cana I Harrare then. for $400 \mathrm{~m}$ of eage curafes

27 Malee w. open us

(scatterst slinbs

28 Malle wideme us of

melelera, sstrolema, ote.

29 .. 'ं

3) Wandos usoede. open us

31 Nallec thresshiss

32 "fainy cerne snubs

35 open wadov; f. dense slumbs

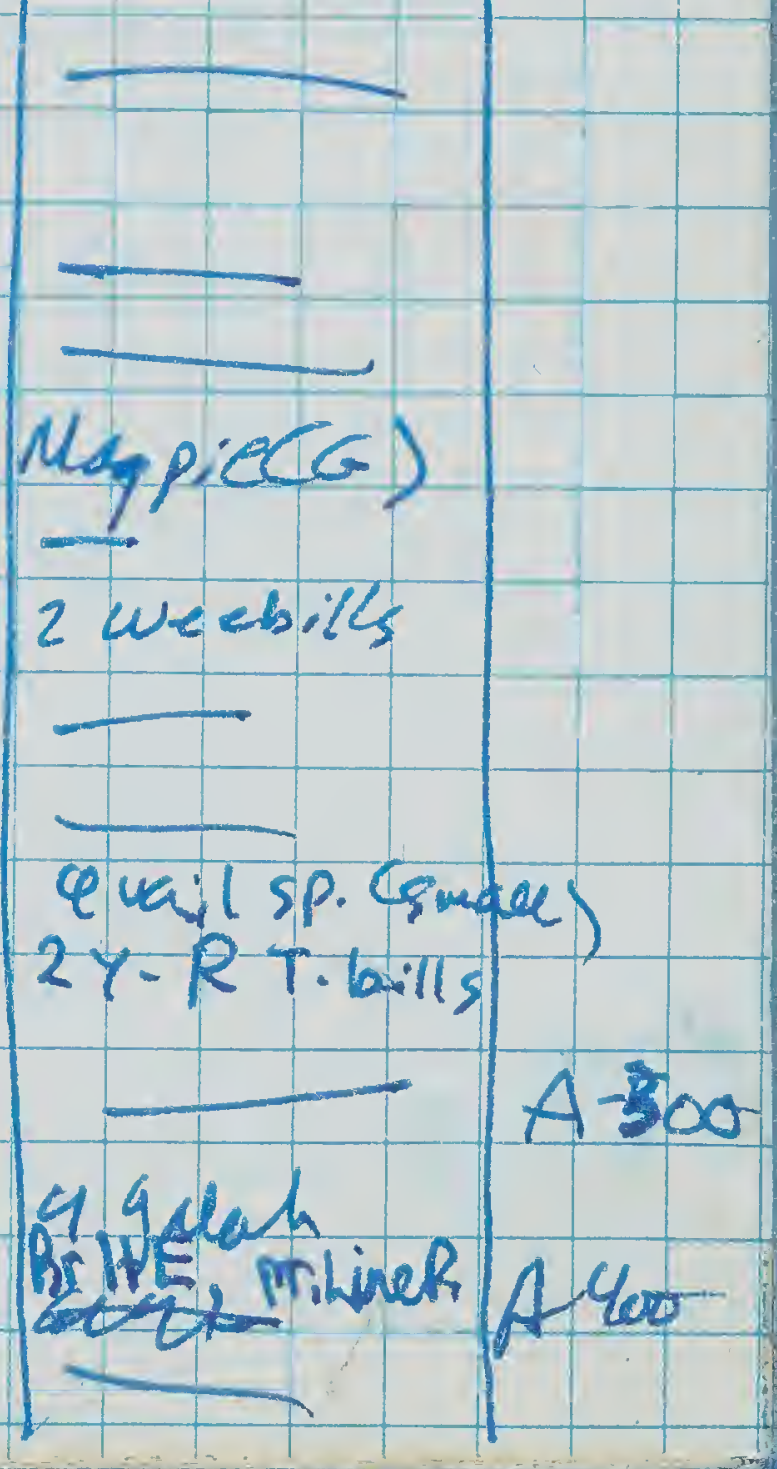


40 Malle worde. Sm open us ue to car.

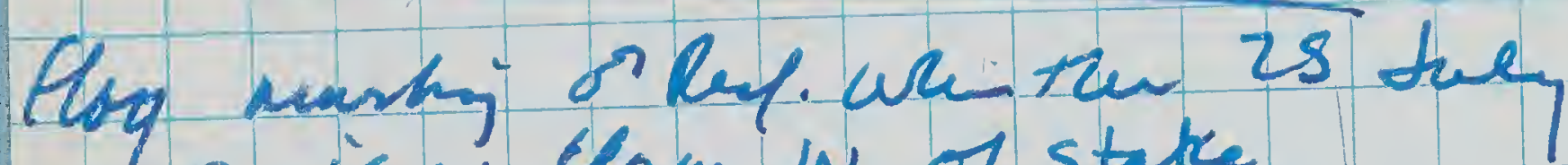
$15: 30$ is $\sim 40 \mathrm{~m}$ w. of stake

$16: 15$ back at cu - statesurny N.akry E. side of revave.

42 Vital vandor-viorenu.s.

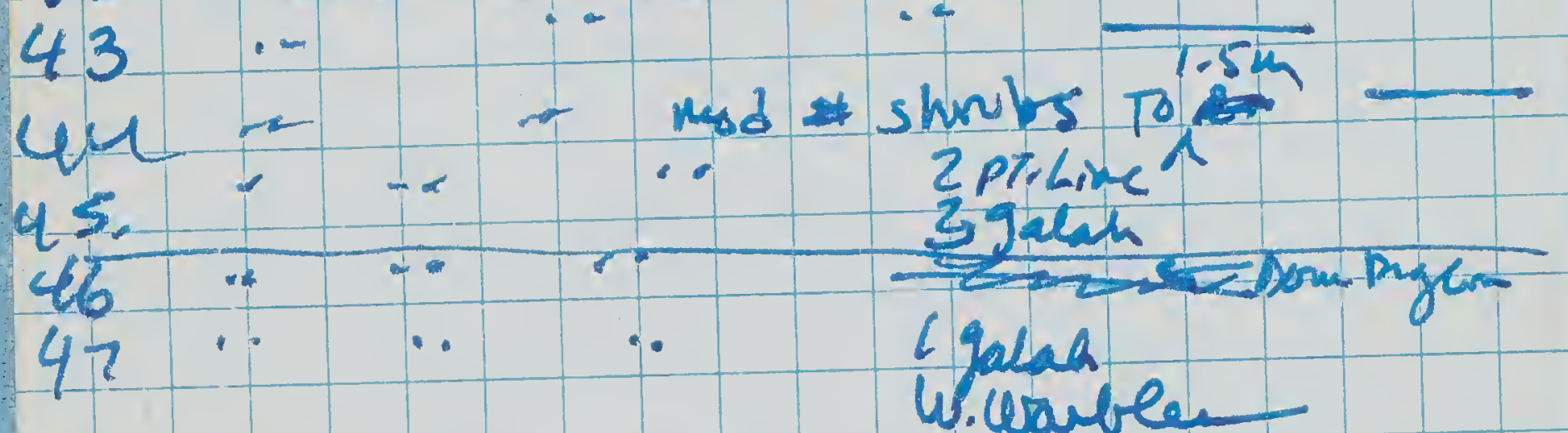

48

opeur vando unde, u.

fintu dous tree (2u)

Melarenca us

sev. Weabily

$4 a$ 4-6Ch-R T-bills

…... Z Cafils.

Pr Red-C Rrit.

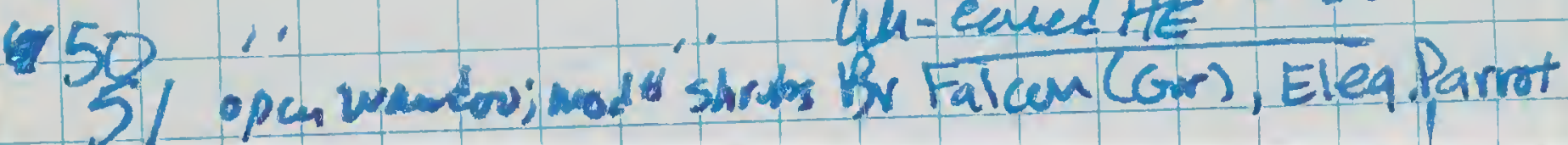

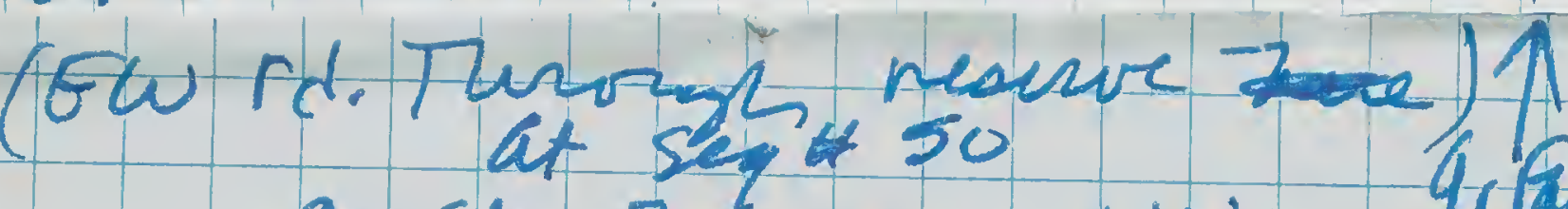

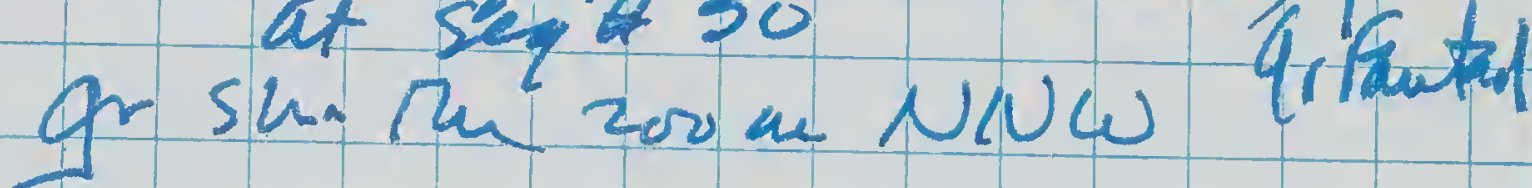
tum back hae -

CSIRohause-Trautin 25

Trayniry-Mukinbudin 62

Makinbudin Bonvie Rock 53

Bonmie Rozk - Woureari tuste 56 Woongarivg - Bulltinch 69196 Bullfinch-5.Cross 35 S.cross Kelderberrin 167 Kelubur-CSIRO 35 $502 \mathrm{~km}$ 
328 Bonmie Rock roodiv - tum Let (E.) 333 JeT 10 Bering bod Civg Dour

3 y 4 Rovk outeraps-rr. B̈eringbooding RA $\uparrow$

345.5 back ourd.

348.4 tarn Gt(N.) at "T" JuT. (4 Pad-railed Bluck corkatas hue)

\subsection{3 move Red-T Black Cockators}

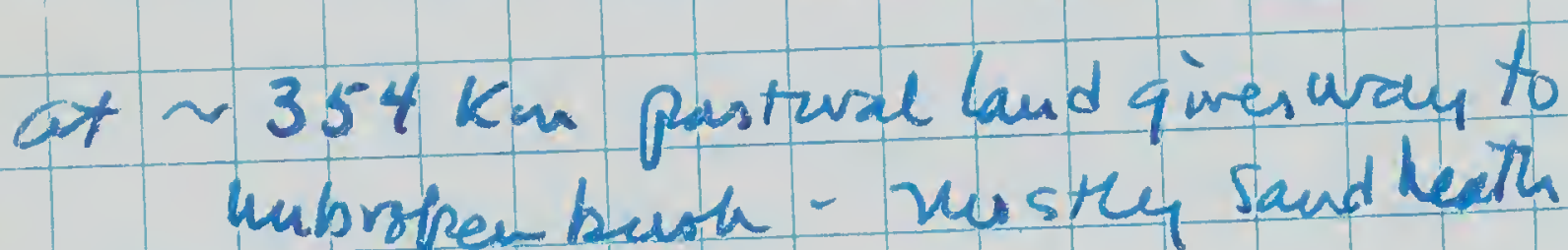

356.8 Catte barrier 5.herd.tenus E

(rT.) inmedafely M I this. I Siayed on main rd goivg N after looky arrend for zs min. at latthe guand (Beubive, GrshrTw, w-E HE)

358.7 "Y" Ja - bear left

360.0 tam bad - re. tor narrow 1 saudy

362.9 tam left (E) on rd at cota guaid

64.1 gun bark - Shemp

65.2 baen at orig. id at cattle guoud

tavly dare Kuryga. with nost shrubs 1.5 a tae, and
clemps of Casuariva to th. Cals sone V. Maswow-lexved Acaun- not sam to nespruse to Gilkerts whiter tape

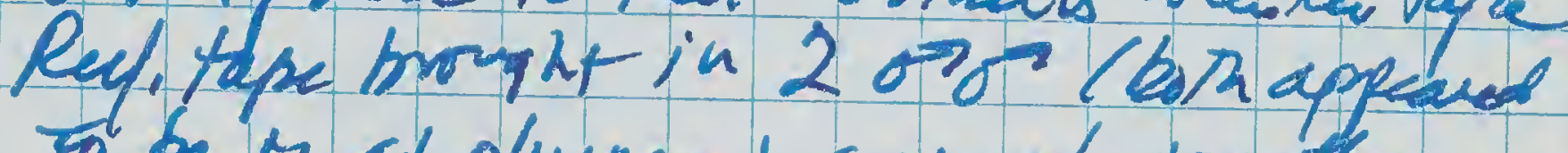
ge be a a plwayd stayed topether in ovuce tree wlo outogostic kenasior postued to ve but ros fuphy betrees tremselves. Thi habitat usud lessity as $5 \mathrm{C}$ ky hey system.

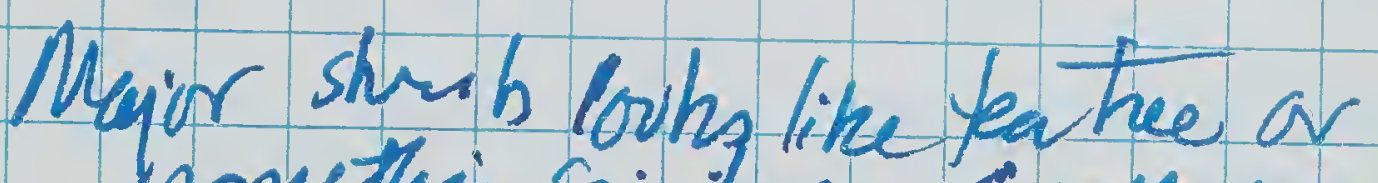

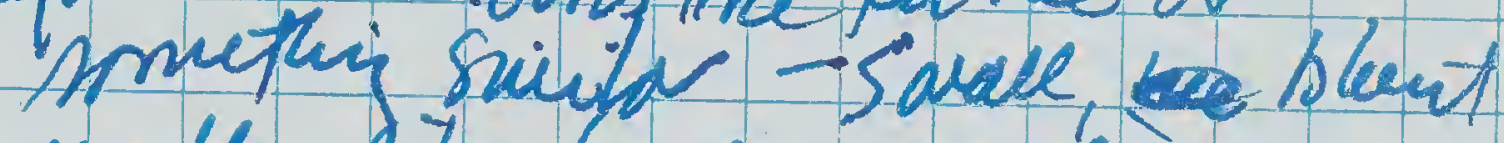
peedfe- lithe leves - nospivespm. arkito qpen fowers.

( Tried Goldew Waisten typer dot 200 
Respuls - Irecarded ove on a 45 dec loop to ise à plozberhs.

walked up and dome the A. for a tatal distance of $1.5-2$ o bur play y Oher spp: W-T cogle, Weckill, Inland or. Shrike Thrush, Spiny-cheahdete ser. White-frouted the, Sustr. Raven.

back to car at 13:30 contimue back

iowand Bonnie Rock

367.8 (Start buen - on Buthen Rd)

373.6 Turn rT. on Deringbooduig Rd

399.02 BK Coclentros

391.2 Bowne Roch

406.9 stoppod in an ween of faincy low (cast $-8.18 \mathrm{~m}$ ) evinlyp wrodes Cimmor sure of Specien - ningleforres scattered benkes to $2.5 \mathrm{~m}$, bot cos 1 open ground, lasked like a Rdrsibilita

tiv Gilberts whister, but na lich. Ovey waitter 1 torund evas Reefores. onen sp Carsusth a. Bellain, Pr. line P., Inl. Fbill, Pallid Cuckoo, Thill sp., daukean Restrel

7478 BK Cockatoo

7480 then L. onto Kidd Rd to Yarragin Rock

2482.8 twa back

Biquadut dore w. Ets of fraduc- Roct wallabies?

Z484, back a pured rs

7492.6 Ja Nenadi-traynj Rd 998.8 stap w. of Kumresdeny.
$16: 15-16: 45^{\circ}$ Malke wovd. w. Aurly abynd. Shruhs Savterd inorigh U.S - LS/ of bave quind.

Lou he d de fir gilkeits wh, but orly

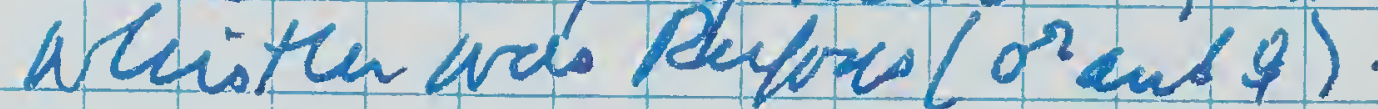

Olvawists - Is shr Th, Bellbird, Red-C Rubi wille wagtwil, Raven. 
Summary of Cockatoo Siqutyp 31Avo Red-tailed Black Cockatoo:

$12 \mathrm{~km} \mathrm{N.} \mathrm{Kunocoppin} \mathrm{(6)}$ $20 \mathrm{~km}$ E. Bonnie Rock abong. Berrin bodin Rd? (4) $26 \mathrm{~km}$ ENE Bonnie Rock (3) $2 \mathrm{~km}$ E. Bonnie Rock (2)

Little Corella $14 \mathrm{~km}$ N.Kunocoppin (1) $8 \mathrm{lem}$ 5, Bonnie Rock (2)

1 Sopt 88 - Cear, colm, milb

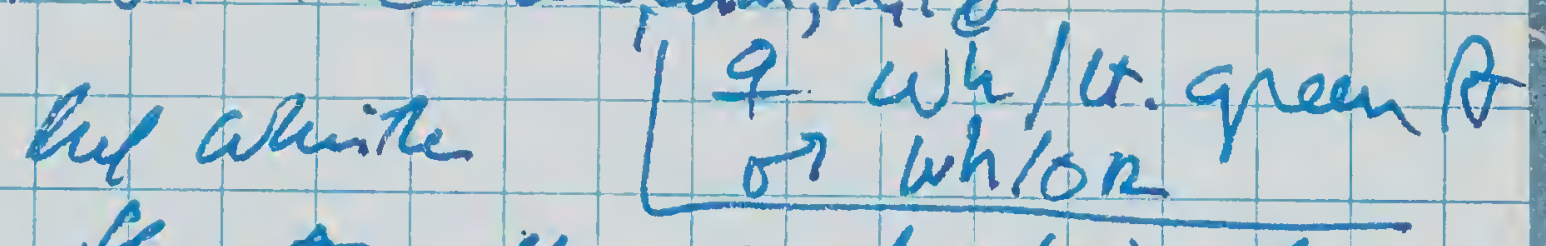

9 - Hew rom yem pereh barig. A doren to 2 m pure and anft catepiter of bare braved a Ian Gaw

q AG top 011.5 m bush - tew dem trom ofen horiz. braveh of Lovk gm 2 mup

\& Ho $70 p$ of tam bush $2.5 \mathrm{~m}$ ig

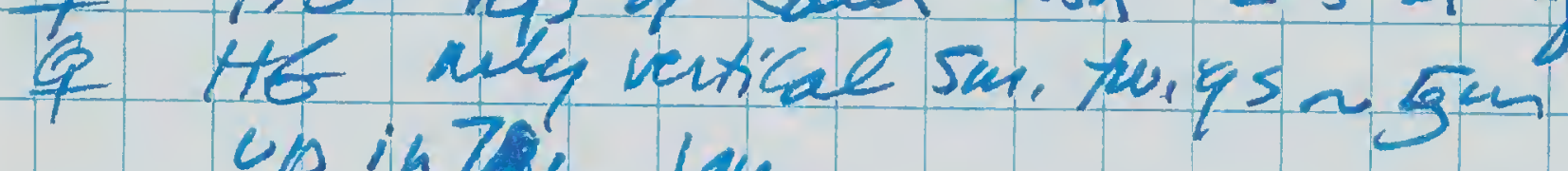
up in $7 \mathrm{tm}$ Jam

$\Leftrightarrow$ the up trom perch to pick at undus.de of Jom feaver clesterbion up an 7 an Jou

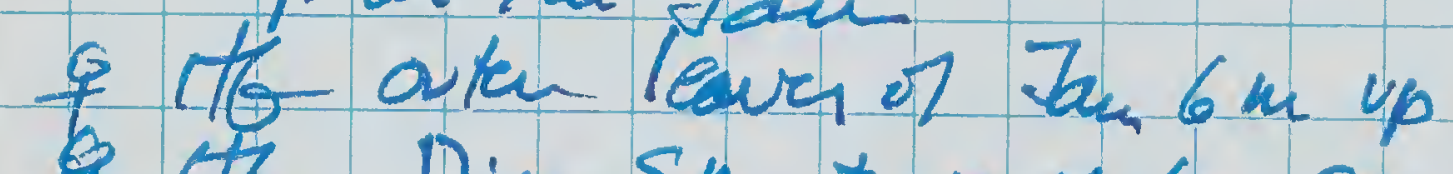

\& Ho Ding S.m. thoing of van san op

q He up troun dang 5u perch to us of Twign 0.65 n up in dead van o1 dellect-glem us Jum flowar sin up from 4.5 m puch

(dellect dlem - DG - fly past substrade piberm ford on The rew- 
$\rightarrow$ Jump-glan fr. Inside brancas or Ym Jow to twig dust areve rdiagouse to hin

$\rightarrow$ Buelind or (rogaromt)

Ho. up tom dian. twig a $5 \mathrm{~m}$ to us of rualle twig $5.5 \mathrm{~m}$ up an deasjong or qleaved catipillar from horj york gems

$5 \mathrm{~m}$

of HG up sandiddle 1 Jan to Us of braran qum up

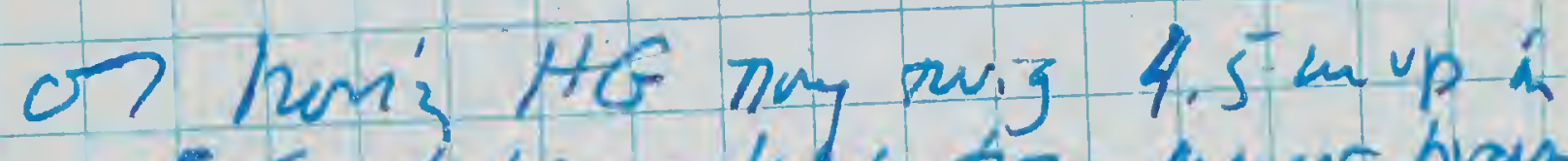

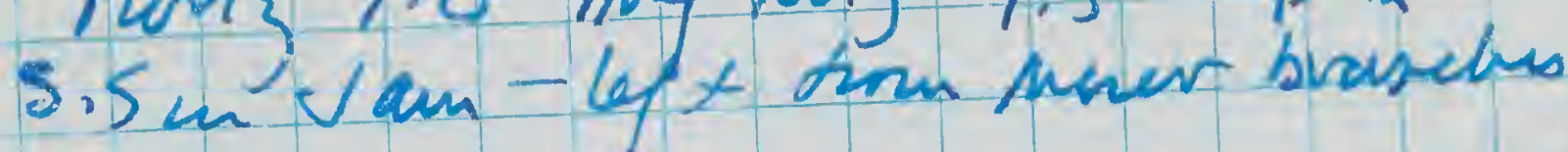

bird typisily sits on me brave Cor ewves $v$ sliuth tor a mimute or 50 often sing in teitudst $\mathrm{La}^{2}$ tavojis bat - peens inturth all drections A typialy teeds hy Myivg or hoverqoani hin the cunal puya. Mres sunther to the seming favor low Tous oren the talle Euearypis.

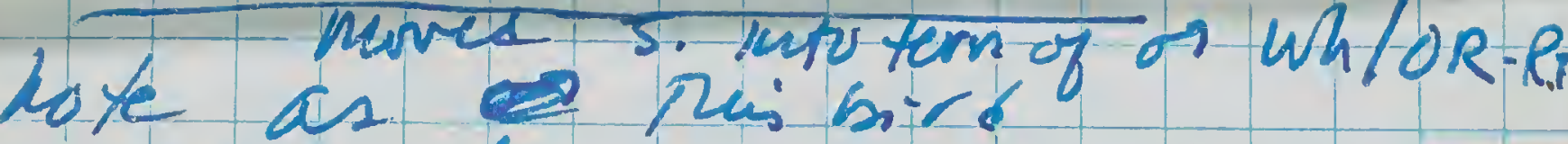
arcled we (I was ployig tape), a seend ot (I assure klvelRed, as L avas only 300 a fin ps. where / was watelizhim and to. new bivel lowe trm that drection ouropef in of atwend Whlok

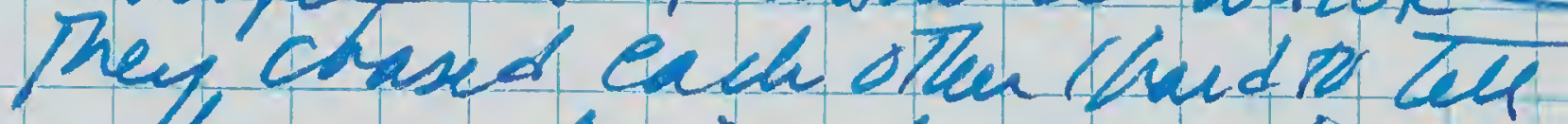
Whe was chasiy utho at a qian Nunewt in al biy loop Ara asple of nimutes. Sivefly, Whlore cume back w.0. otter bita

ivi)

- $0^{2} 0^{\circ 00}$ Bue Rad here - whlor hare 
whIBhe pol w. q Wh/wh
RT

of Ho up to us of dom leaves $2 \mathrm{mh}$ ? nom $1.5 \mathrm{~m}$ perch in same dam ( $\varepsilon u+\tan =3 n$ )

Note: secasovally, when orid in Hidst

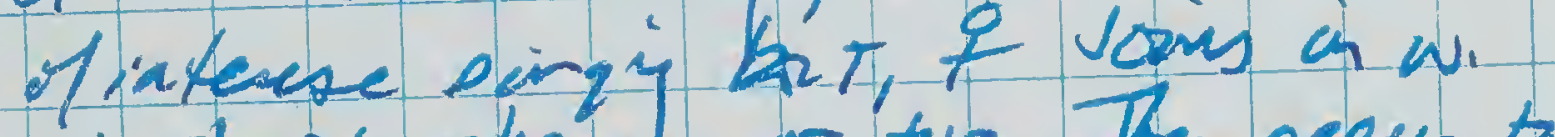
V. shovt phrases of two. They seen to une around toquer at ael himea

ten. of wh/blue usaps pently arond That of Red/Charrens.
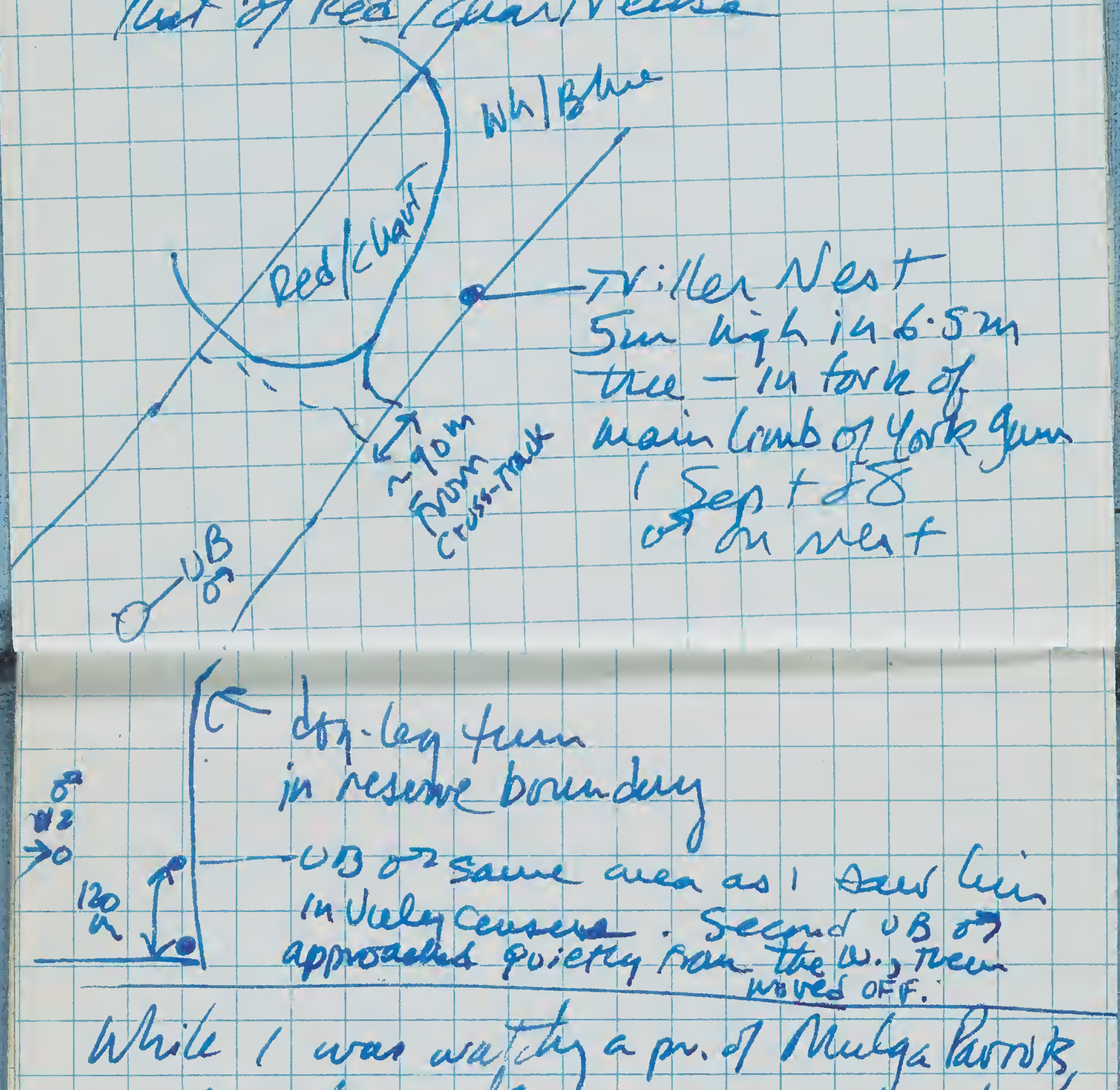
a secued pr. tow up o peeded wh. or of inst pr wtuched zud O7, cont they enyoled in brue spaterean aerial Runblin unbat 15 ke.or

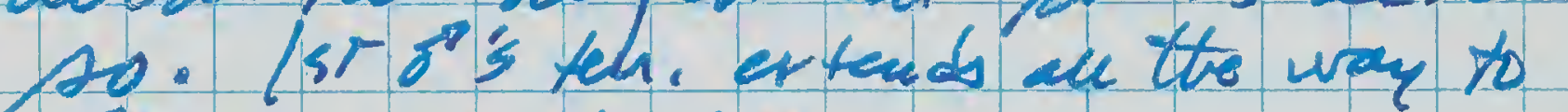

Se cosmer 11 resure.

lots 1 Poism burk in scerin. Weeds S. of dgaleg tuu in bovder.

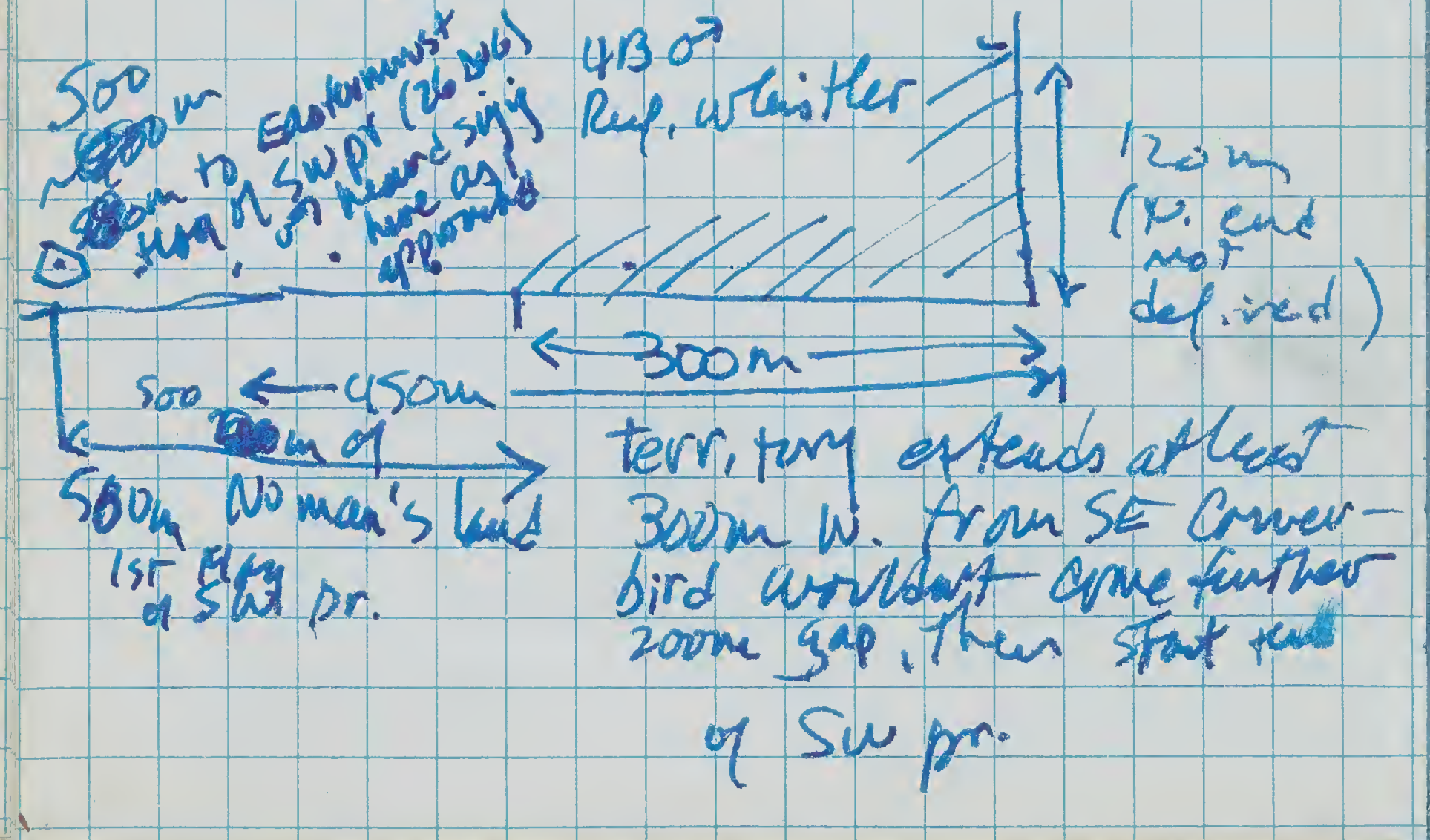


Frr. olsw pr exteuds N. Into Resure at Cast 2 som (paced of ) int elpe ol low treath. E-W, it appaus to extend from the sw carrer E. $400-500$, Ecoutral" oavinge
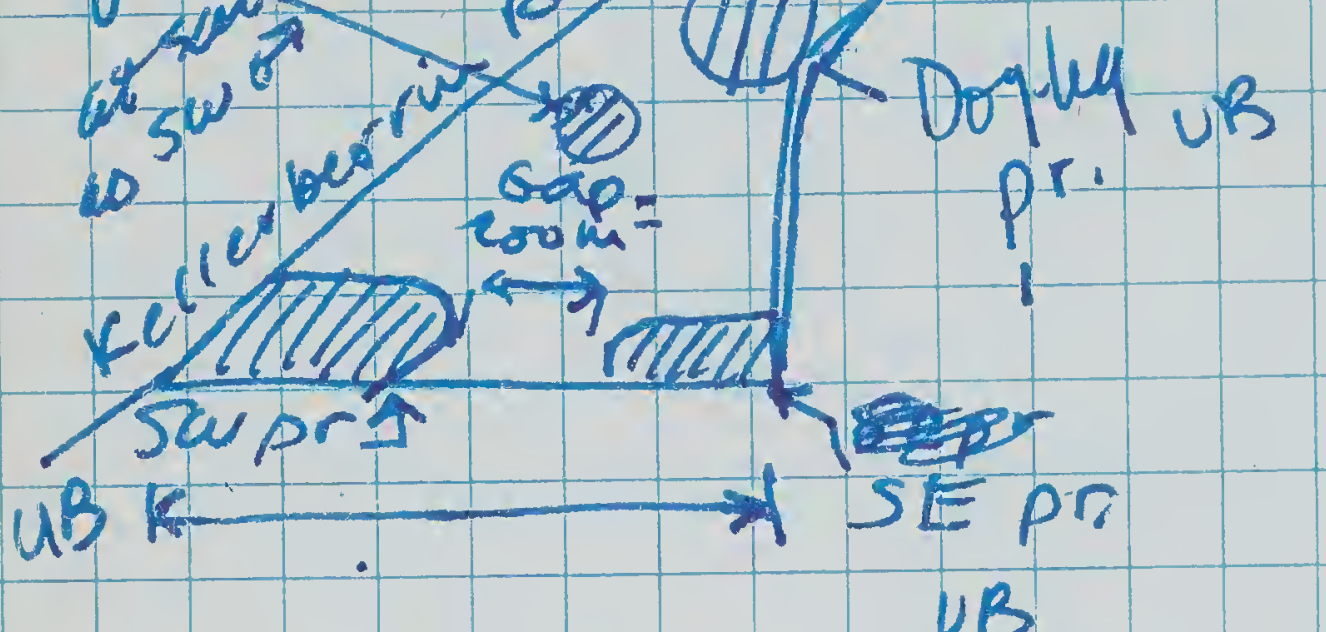

$U B$

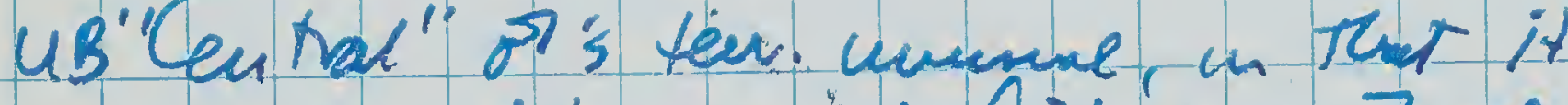
is ci a hig aren" of tairly dum tars

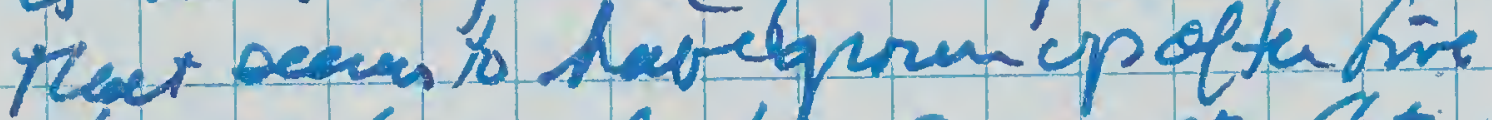
dinnyed aec the lis acueypts Cok of staricu daet truin, ples swall 3-4 antale, (6ca dish) sapling guns.

orshrin lue, too

Catral"s tenitry extands NE alvy asio of areeds Jast to point opp. whee the "crest" siqu is on the s. side of the crest of felloibenin Rd.

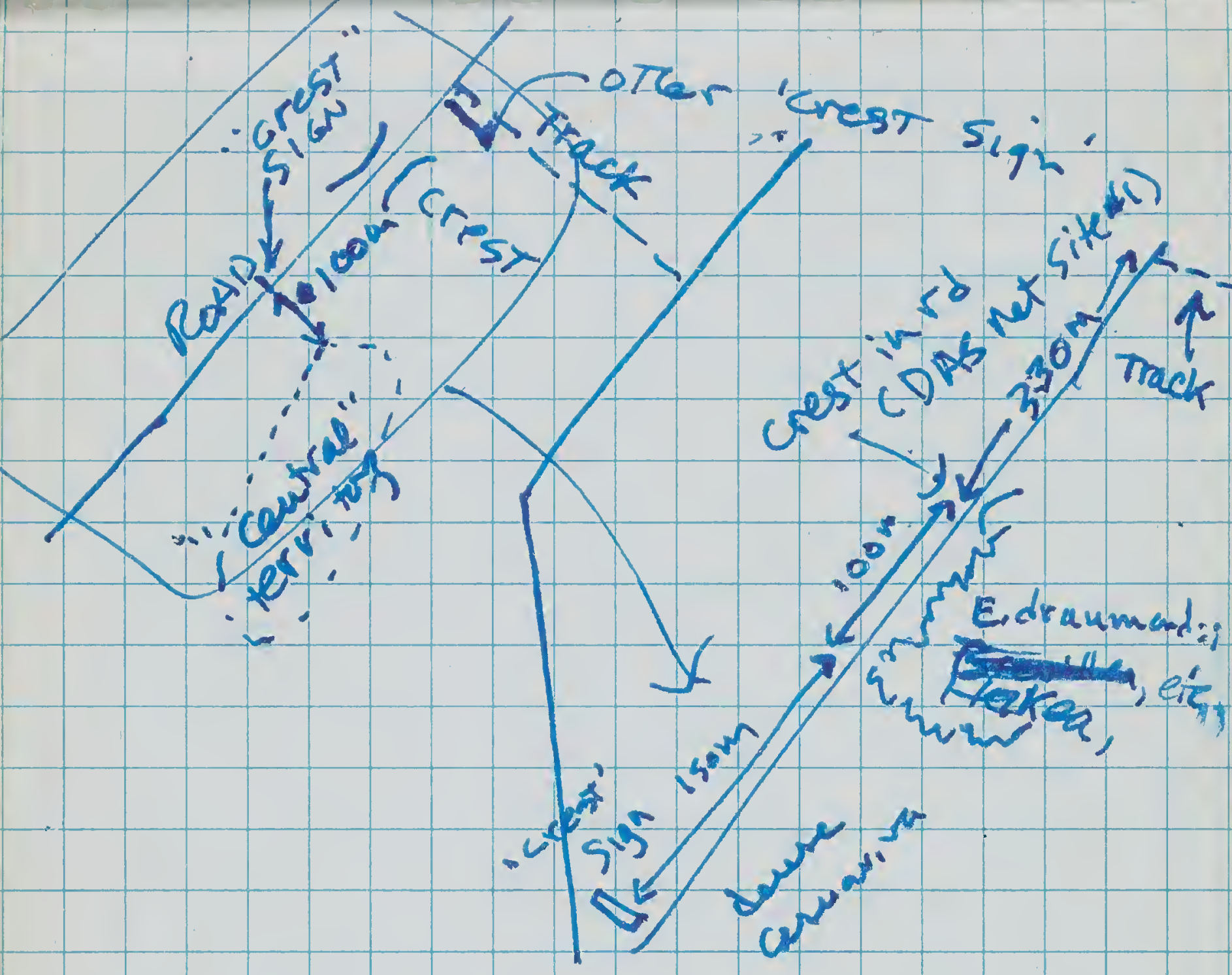

bask to can at $13: 10$

aby track anoss midule of Weeb

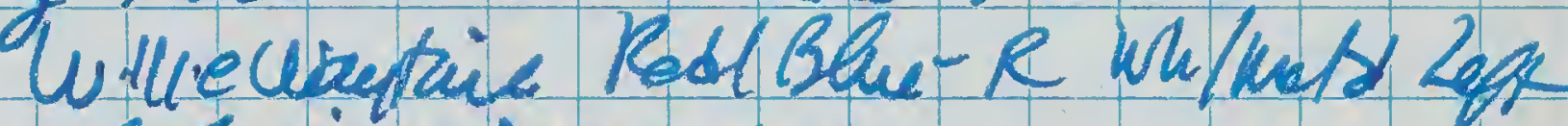
quani moring natesial

(banded heve 17 aOr 1987 )

Aftar huneh

15: netter or at dozlen of Weeds

( $200 \mathrm{ur}$ S. Traeb unses midale of 
U:00 Ruted of SE comen par Bandad Dk Bhu/DK Blue TR wh/matie - hept

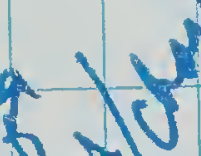

sil

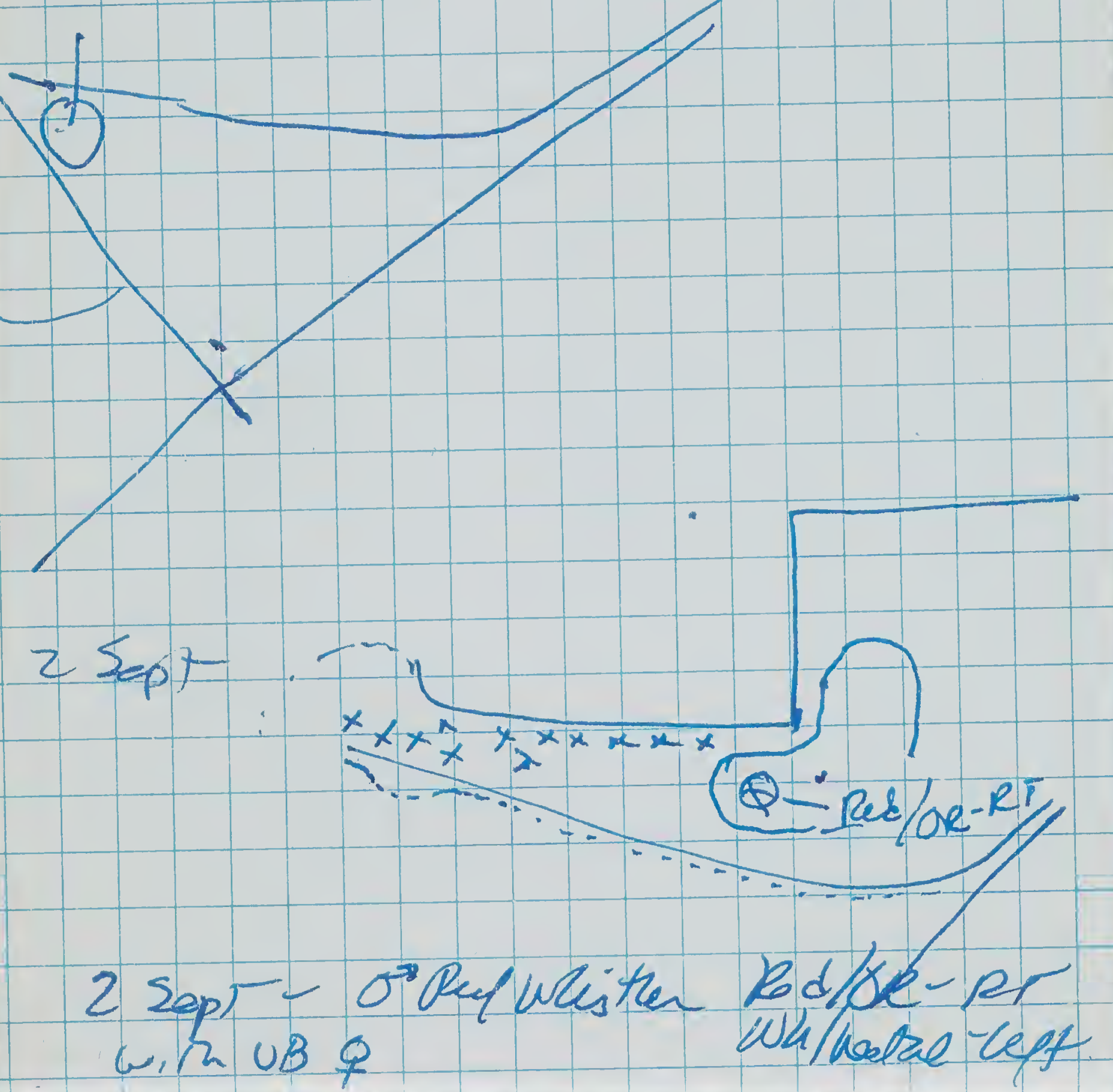

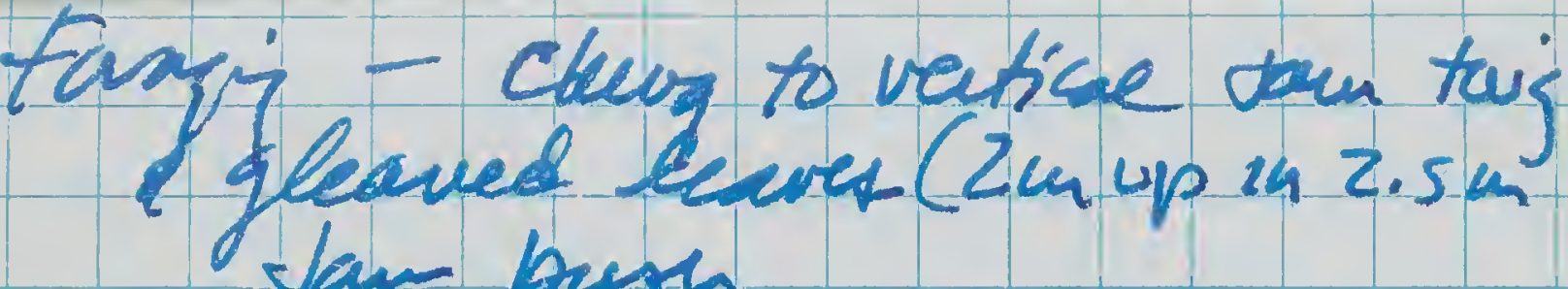
bivd strquy sring 1 Arquently as it moved thoon opm Jan ocherd are reur the $\mu$.edqed weeds d ter re-eutrant aygle.

I HG din 1 outuardform Sur ckm thig to oviten baves. $1.5 \mathrm{~m}$ up m $2.5 \mathrm{~m}$ Vam

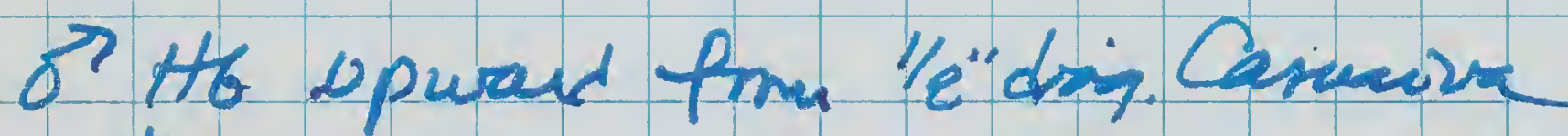
twiz 6 mup to 6.5 - qlanes os of Cas. nedle cluster. tree $\sim 8 m$

o HE rop of tam lay clurter bmoprefre Yporan 6 un dead twig in same

$\rightarrow$ vimp. plem up from Jam twig to us of van ley cluster - Gan ap in Thitrie or th havin hom $1 / 2$ dien quach to top 1 leares in Jus Im upingen of th hoy-top of an leved fror 


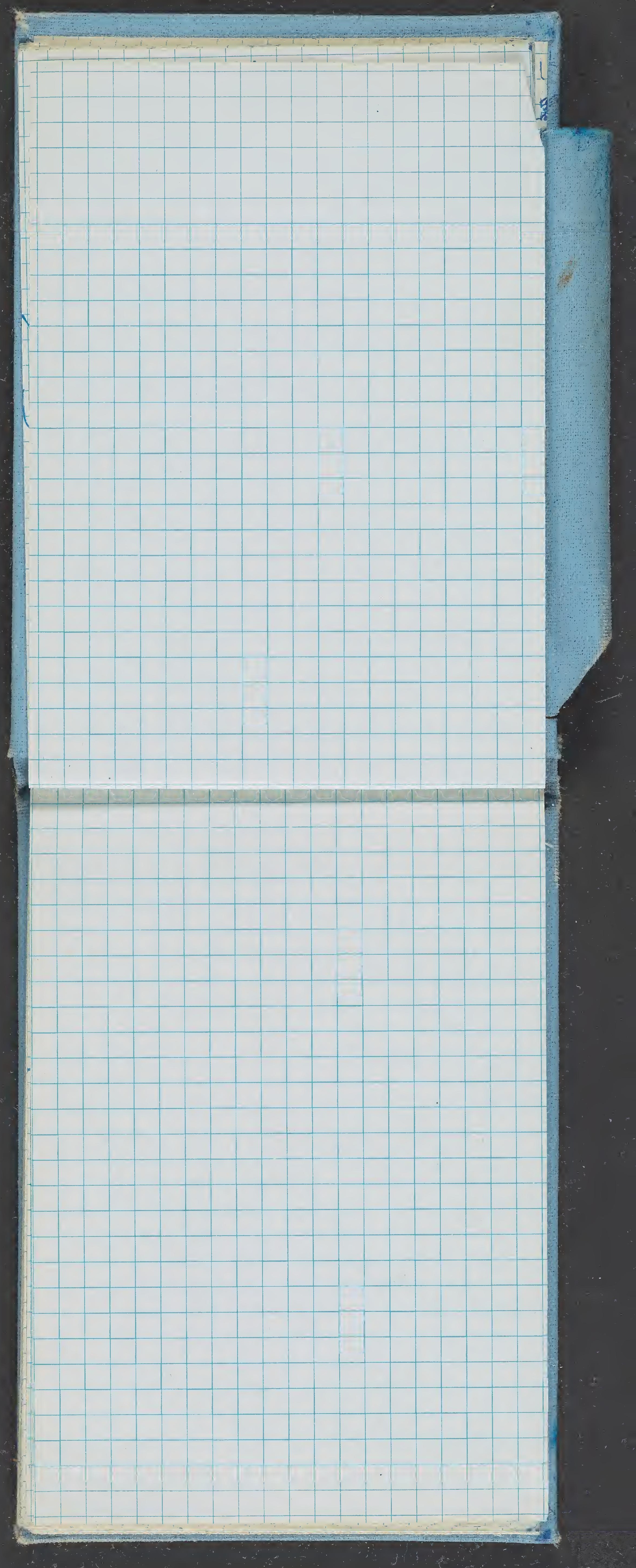




\section{2 sept-cart'd}

or Horn Hb dead twiy $7 m$ up in santam 1 Frund the un banded $\rightarrow$

That I saw last week af the w. end of the upper pait of the resuve section s $\omega$. Of the pard r. Y was able to net ho/h the $\sigma$ ? aub of simultaveomly after hein the nat sefup forey $\sim 5$ unviters. 1 bun bed of DK BUn/OR - RT Wh/urt q: DK Blue/Lr-gren-RTj wh/merd - Left The of is Tppral $3^{+}$adultibut $f$ is an imu, - very streaky, yellow palate, pinkizh lown mandible low body cor $24 \mathrm{~g}$ (us. $26+$ for 6 it).

Most of tenitory seans to be jan oreband" w. a few sandslurord Batea valilla" busbes, ete. $\uparrow$ bandip SPUT

qap of at 6ast 60 soo m betarean w. edpe ol top of thes terr. aur,

\section{pipaline}

\section{$200 \mathrm{~m}$}

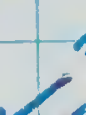

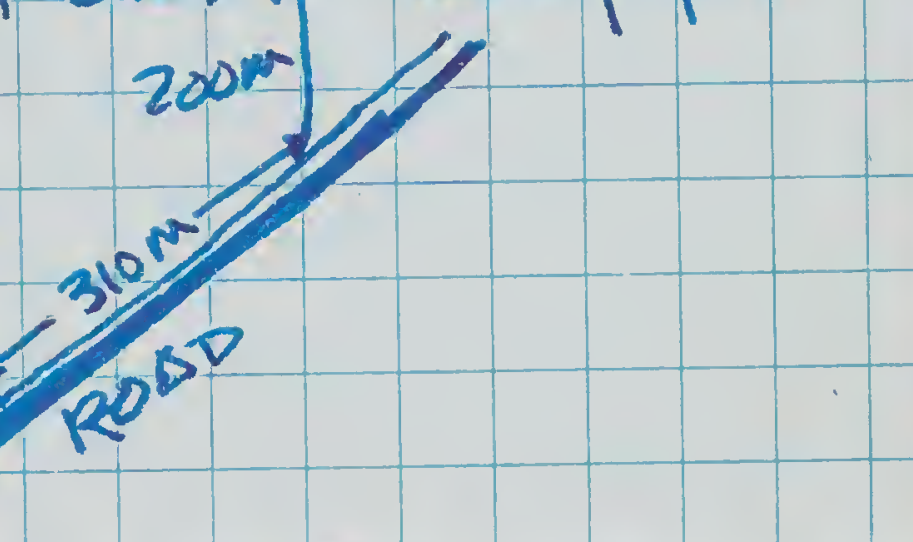

PC. edge of Redorauge at NW cosver ol weeds Red/OR BWu/OR ${ }^{\circ}$

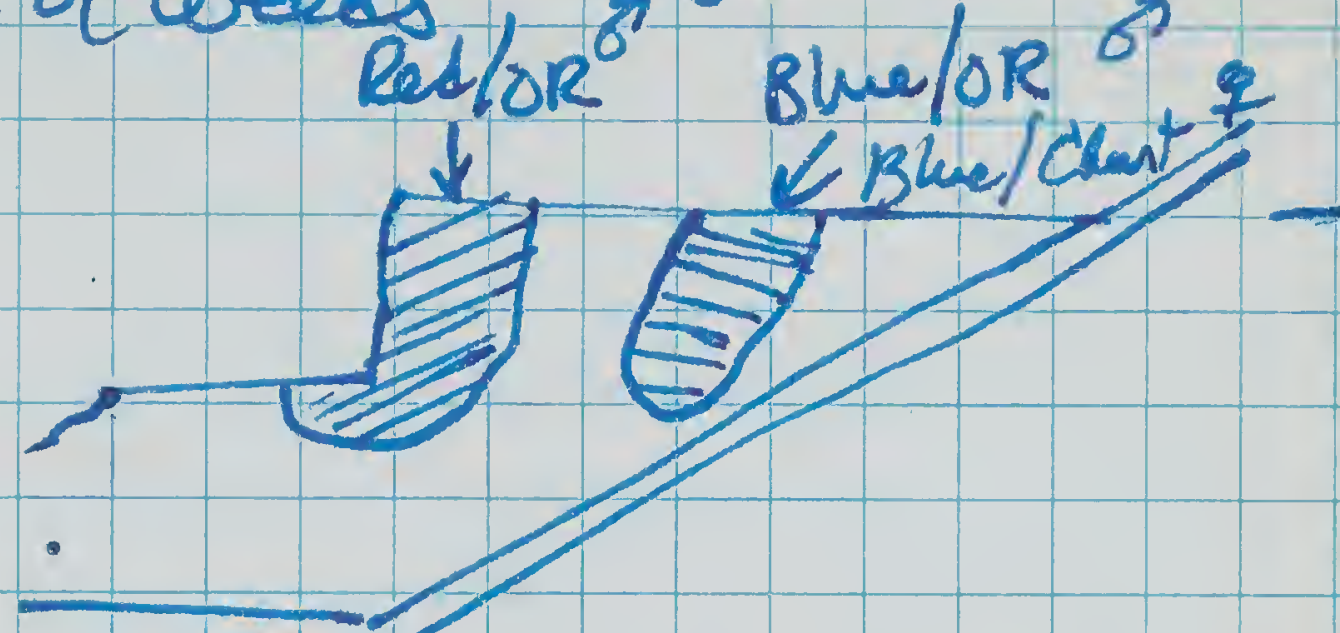

Frankliu's or Cole's for grocenies 7 sept Truidote

Shune sadrews - Nowhshue 5 t. farry: Malcolm Rowe

66 Pusden 5T.

$72-8390$

RT. a Taylor at Priman Schore Lofron Erskine (a Ne hum to innes)

at "T" T. ontb Nikgarast

past 2 rT turmy mt canzur

it on phyibrain Rd 
Bridqes thesis on Whistlen frngig : 1980 . U. New Ey fond

8 Sopt 7:30 Newholem

qolen wlistles - in m $\rightarrow$ - responsive to playbedss - sing the pi-pipi-pipi-peeyeedp

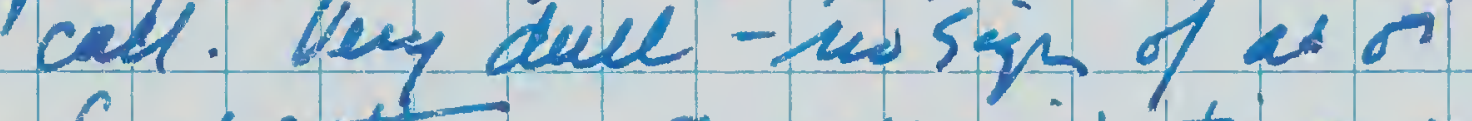
facial patown. Sh qeelewish tinje under tail covents_rest duce arey.

seav: wat. whistre cace

rapib: deedledudlededle dedle-be-orcho

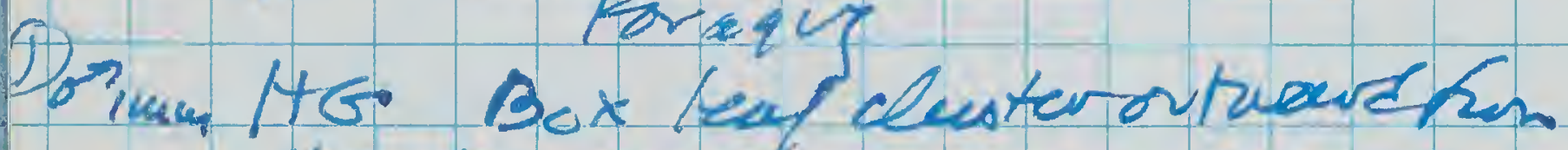
$1 / 4^{*}$ disog.puch com $4 / 4$ 15m tree

(2)

o" une the ufrom hor 2 1/2" branch 8 m upto 45 4 box cluster $\sim 0.5 \mathrm{~m}$ xesve

(3)

Ho upwand to us of suall twi then

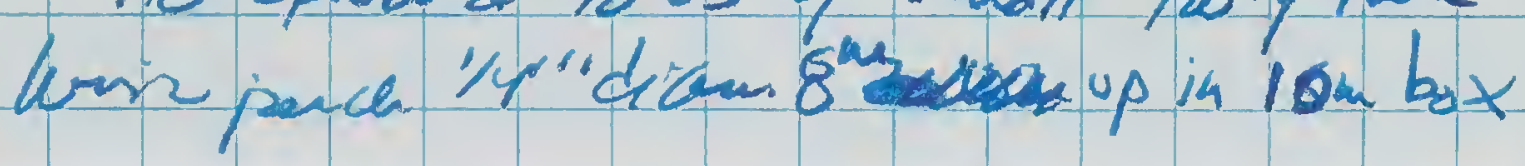

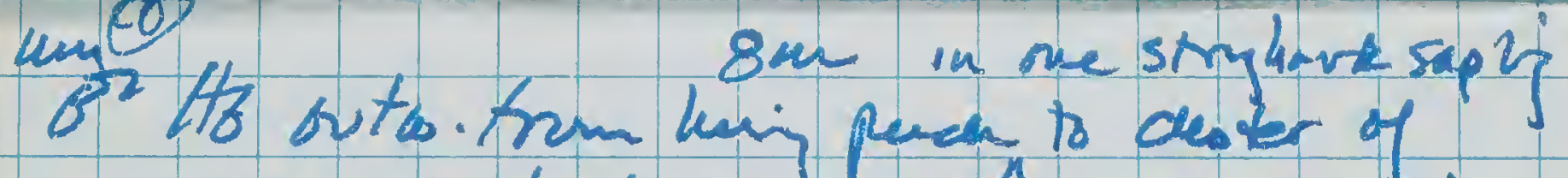
(8) siviaq-bank koves in a fijaent saphi

imm lom up is zom

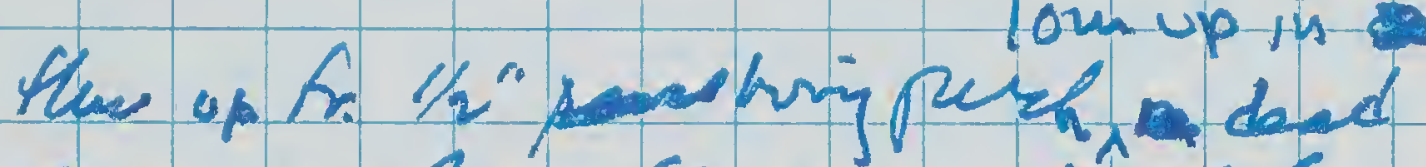
gam to glem (succers) niset hou "I' doy. dead brauch

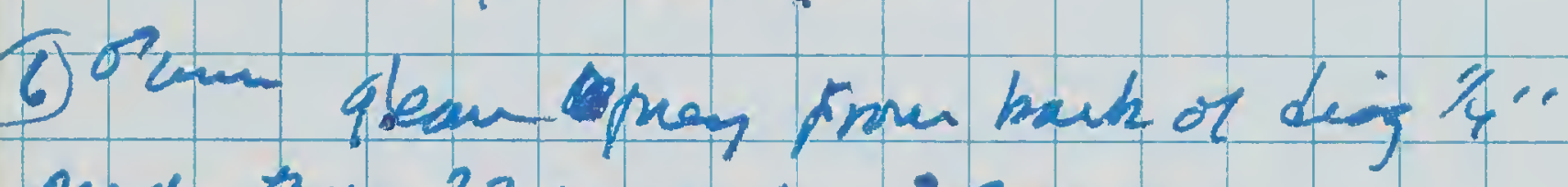
perch roig $22 \mathrm{~m}$ up in $25 \mathrm{~m}$ gam

H... Ysivine

- gate! I Golden whitilar predant

D farmhorse

w. dogies

(7) horiz ho loose burk theses on diag I"

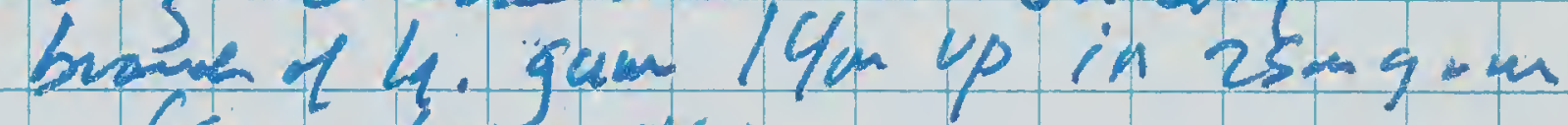
(Same boa as 16 )

(8) HG up from $v \cdot \sin (k 1 / 4$ " $)$ perch In Striky bauk tous of leal clecefen ح $0.3 \mathrm{~m}$ abova. $5 \mathrm{~m}$ up is $18 \mathrm{~m}$ sapting (a) glean a 1.0-1.5 cu grien csterpillar from cluster of leques in sm. Strig hame sapling Su up in. $1 \mathrm{~m}$ apliy 
8 Sopt-coutd

(10) HG suder bonemsh Catupillan

trom top of ercenter in

srringy bark - feew dow $\sim 0.3$ trom

orig. perch. $8 \mathrm{~m}$ up in $15 \mathrm{~m}$ tree.

bonetl farajobs. at $08: 25$

quwal not n babitat - mat utr $25.30 \mathrm{~m}$

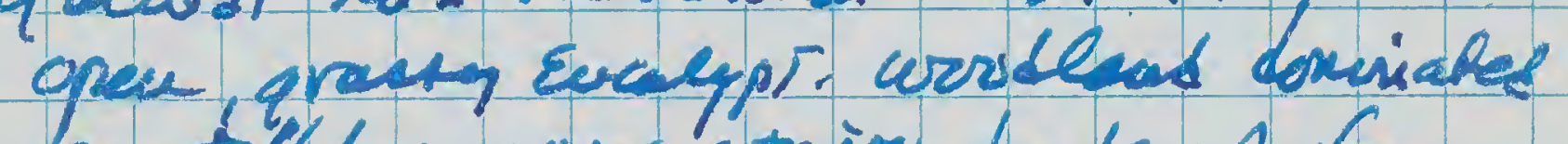
ky tall box, qums, stringy bouk. I taw stauding dead trae; fir «isapleyp, lat

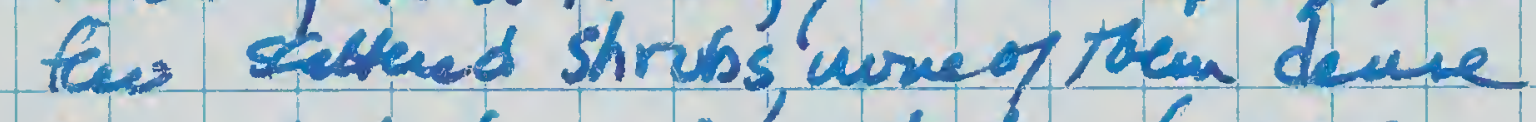
evough to be gosd pustechi tor wes?. efeept in rarive, whue Ghuts soverthy deuser. Bird under oins was vay vires-lite in its foraging - would sit on anerponed peres, offen within the overall canopy of a ericolpt - and peèr all avound for severals sees kefme flyig to auother peich. Singing

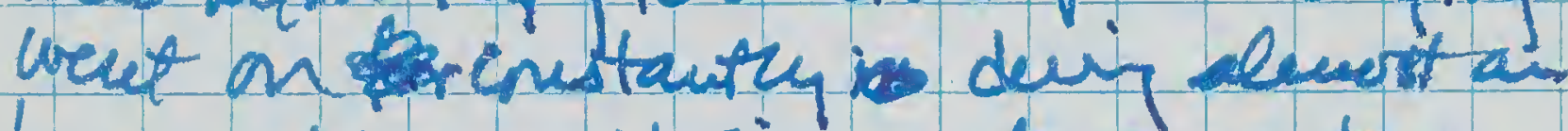
how - bird curld sin a phraseor two trom almost every perch - Lots of valiation in sorg typer-mauy nurve typer Then 1 lave describes above. Bird sesuad to hover glem (eituer up. ost, on down) tum lewes or baile in most forraing abbups. A feur instance of straight qbecuing hom perch branch

Burd covered a relativele susll area 2-3 ka . Feedijterston was at ede of itell uordlands o bue they quad uito onamah and paddsck at the base of The nocuntain.

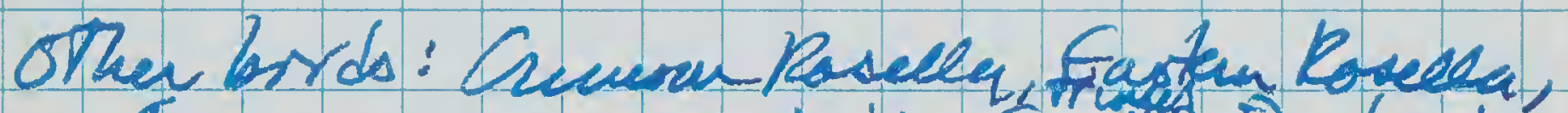
Galah wille Wagtail Pudeles,

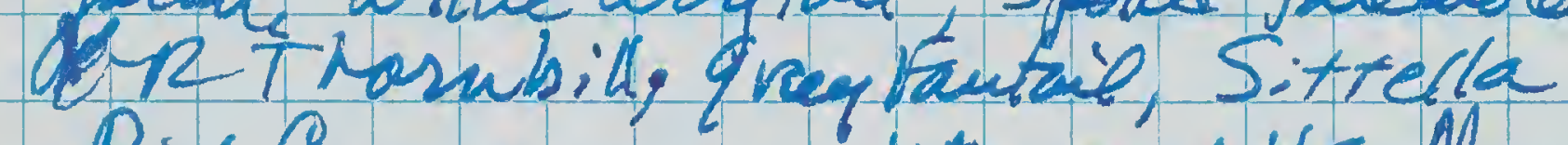
Piéb Ceirrawory, white eaved (tE) Magpie, acrfed shyike. Noisy Friarbird, Kakaburra of skrike-fit-worning temuinal shoots of String-b sapli - a crively boppin up beyth of branches 1 Rom branch to bry nuer usdrum fom fermine lexp center to geamit. V. heavy bill. Pinned oney, puen (keeple?) to twg under foot of ripped it apout wi bill

1 sT sorvey pipe seen hem rd. 15r Sodm cu. of gate, vust alous rd: $680-340$

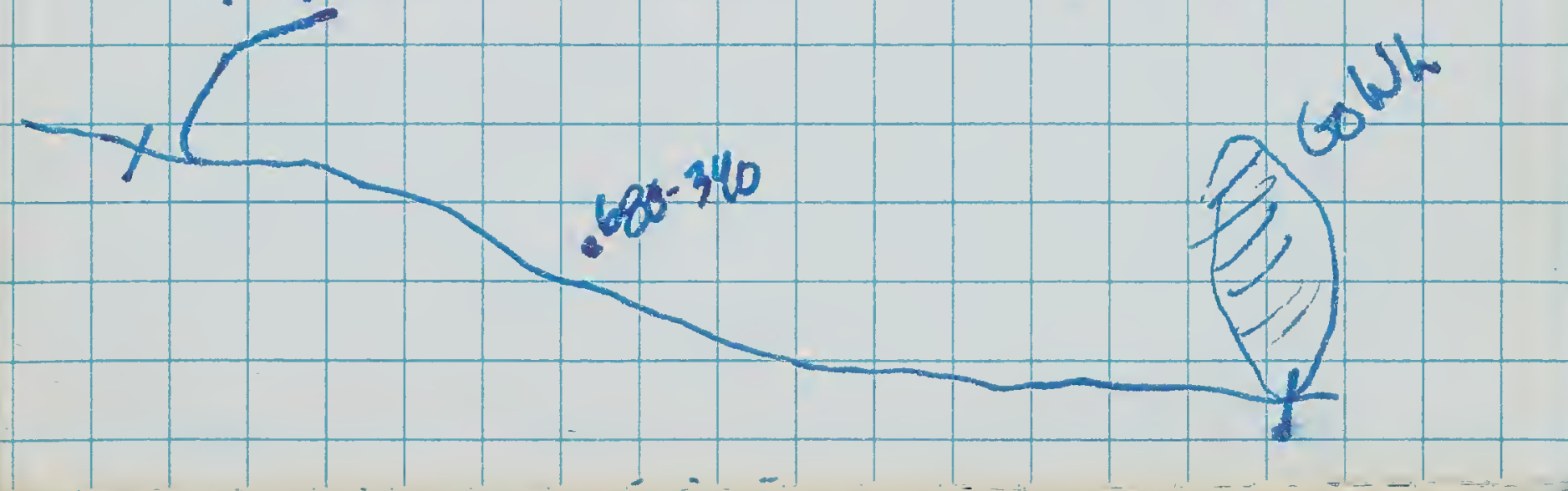




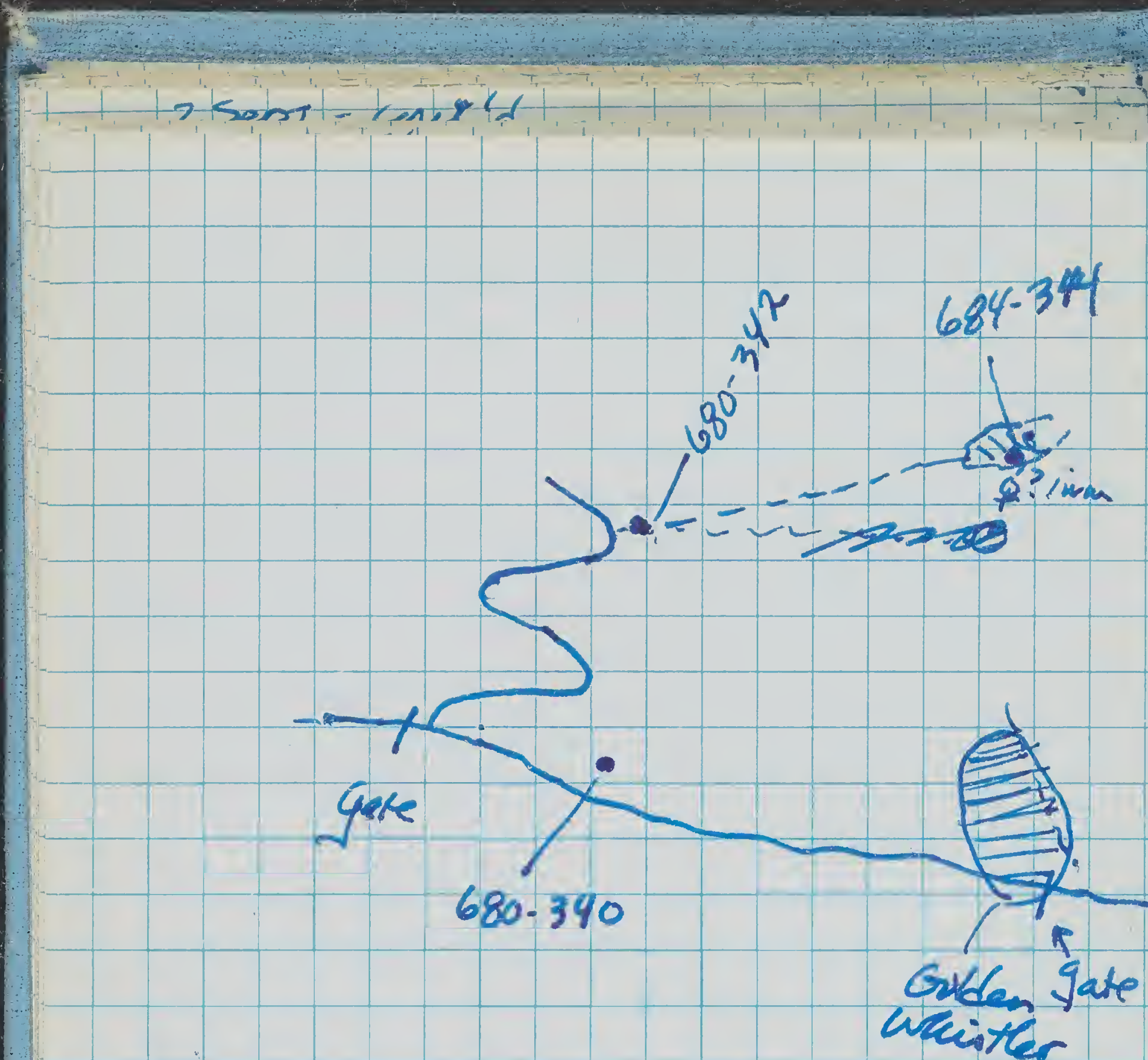

(1) f iwn: Gowh - happes to sm. dry. Twig and qleaved ineect 5 m up in $8 \mathrm{~m}$ strongy bark

(2) 9 cenry to worgh bank of verticst 10 branch and pecked at it

(3) Leaved down N. bunj hana teylem

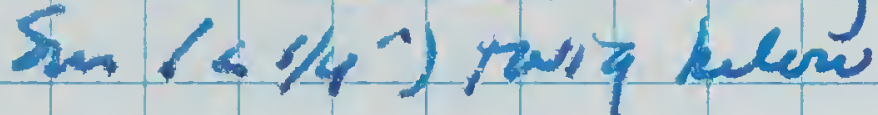

(9) Ho upw. fr. ding puch $10 \mathrm{~m}$ up in 20 a mea

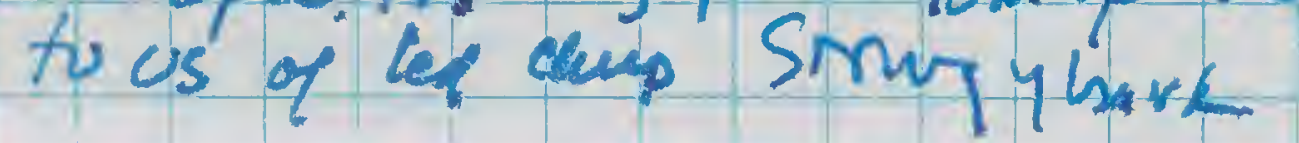

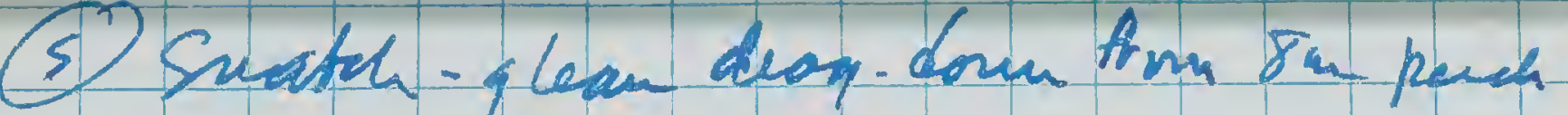
in $11 \mathrm{~m}$ sringy

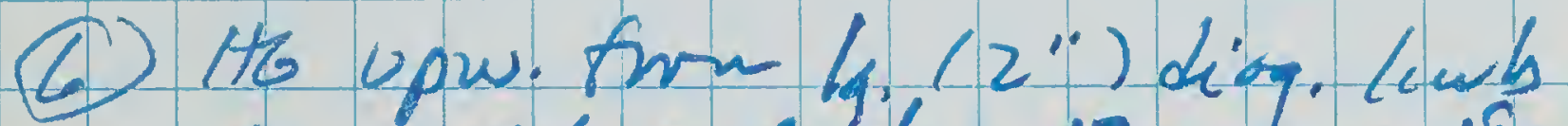
to us of laapcluifer $13 \mathrm{mup}$ in $18 \mathrm{~m} 5 \pi \mathrm{B}$

TPr. 1 Flawe Robius feeding goung in nert bitt on lip of valicaty elizats Tree Kodlow. prandeless bole 1 completely to int 2.5me ahve nest rree is 19-21 pau stringybuk

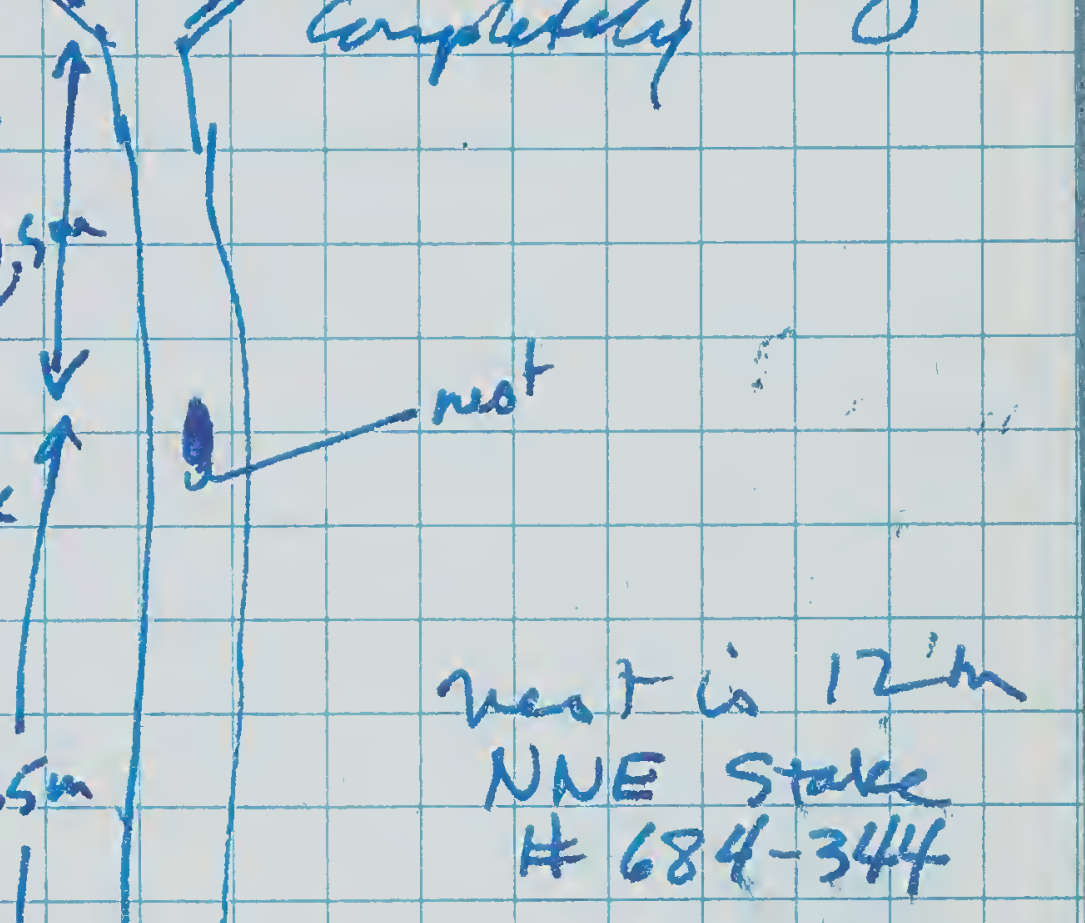

7) Ho upa.from 21 heriz, brouch to US of Ceapcluster $12 \mathrm{~m}$ up /n $18 \mathrm{~m}, 5 \mathrm{rr}$. Bark

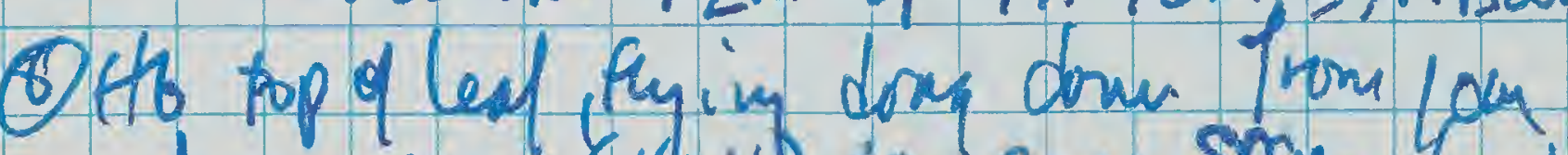

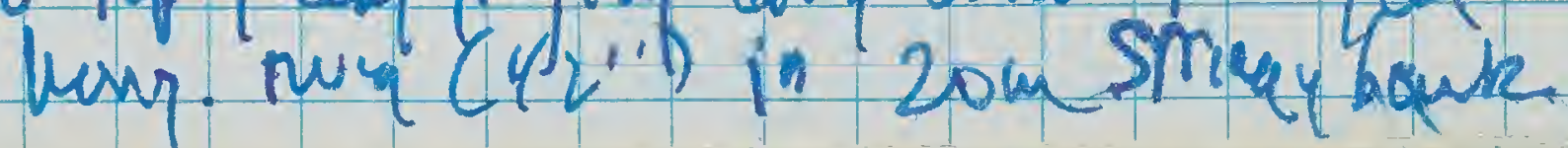




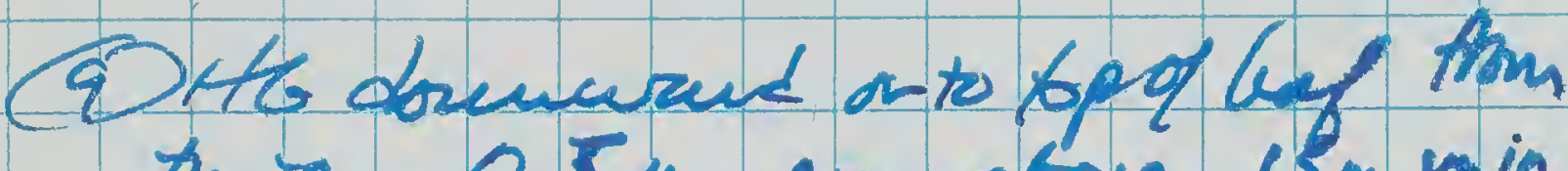
twig $-0.5 \mathrm{~m}$ axp. chove. $15 \mathrm{~m}$ win $26 \mathrm{~m}$ sring bark

(10) 1 to upuard a $1.0 \mathrm{~m}$ fom $8 \mathrm{mu}$ up $1918 \mathrm{~m}$ gom (red:) Stob cos. at Niar

Hbitat rotes ete. - Meis bird seand even arayer ventrady than the inum $\rightarrow$ sow ealein. It ivisally approses when 1 plaged tope kuf never unde a sound in the 35-40 min. whils / has: it within view. Activity area was tarly suace (puipapo $15.2 \mathrm{ka}$ ) on a faily stery NE-faci slope. ground laver y opan on scutred clewp of Po and ciddey scatreed Arusy buikes to $2 \mathrm{a}$ kith and not spreadury-types. Tres were conder spoed dominataiky singy boriks. perkaps 2 or 3 gunes aith a $25 \mathrm{w}$ of the ceural pint (sphe 684-34y) Trees visity a 20 - 30 an dib; up to 25 m the Bird's qeuma! faragy betwerzar and like fisi one trday, escept ter lack of suning. Los of peri up ared acound risu open preats

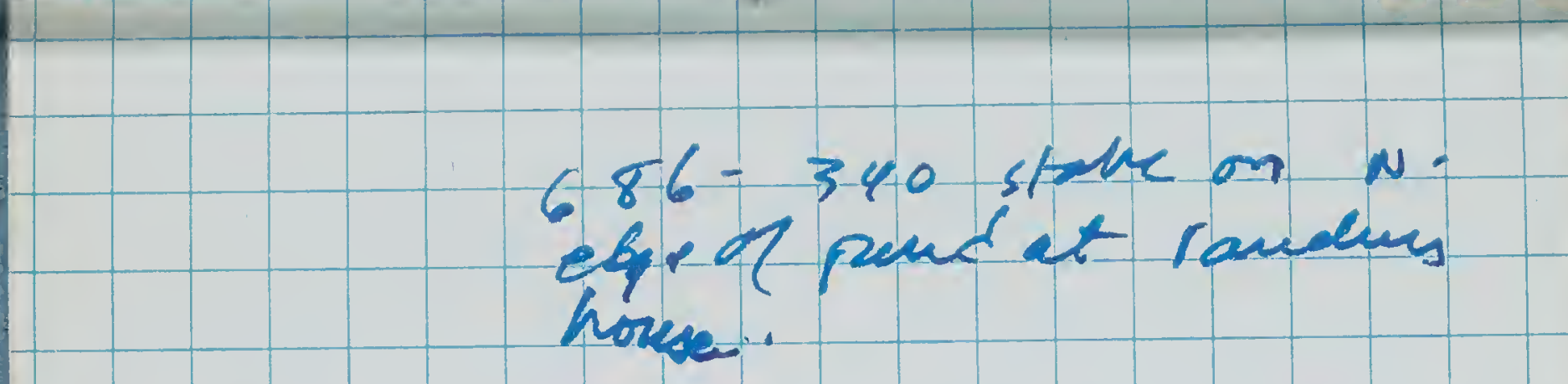

other hords: Yellu-toneditte, Gr shike Disurh (1), Red. rueped Pants Supulo Buevea (iquop), Starling (paldock) Cunoteb Ripeno (wanz-padbene)

9 Sepr. Brak at Vewholime State Pak

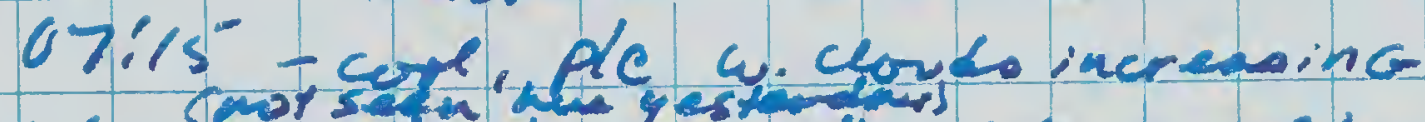
abditwave bivd Spp? : Wood Duckef Black thin lin tiny wask survouded hy paddock werg $\mathrm{rd}$. in to station from NE highway). Eastem Spinsts:11-2

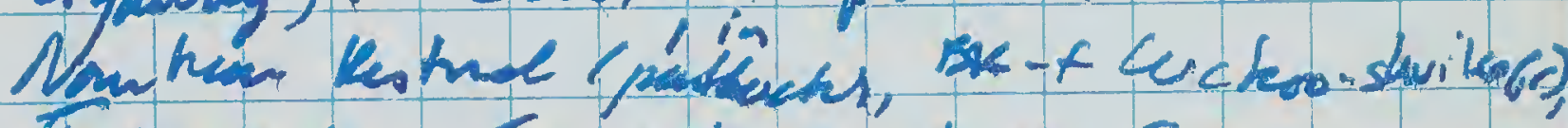

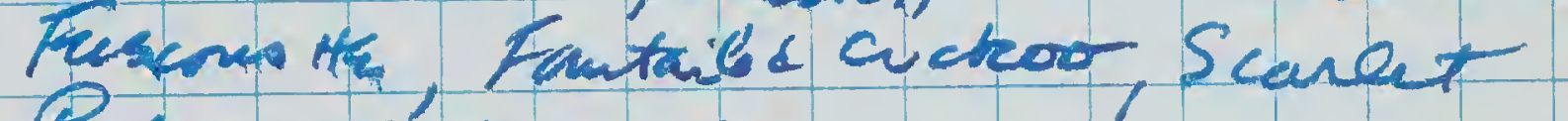
Pobin, Jácky Wiuter

Grey kmpmeng swang wallabico, Vabbit, fot (614-350) Koala (6q6-348)

Wathed up MUt. Duvar tookin fes whistlers. Heand the lum. of at Buse of hill in farmhore (sene one has been Thue for 3 days at least). 


\section{$q \operatorname{Sen} 7$-antd}

Top of Mr. Sural tas lay area of recy

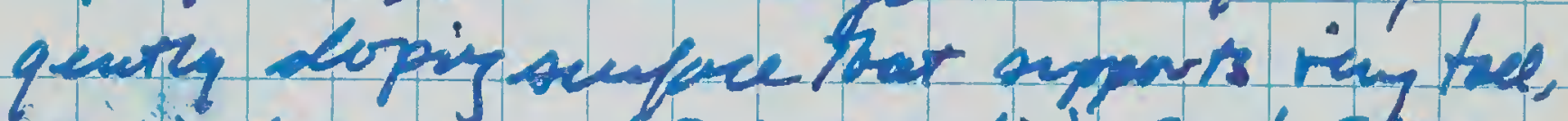
Srinitguns (E. Viminalis) and shingy

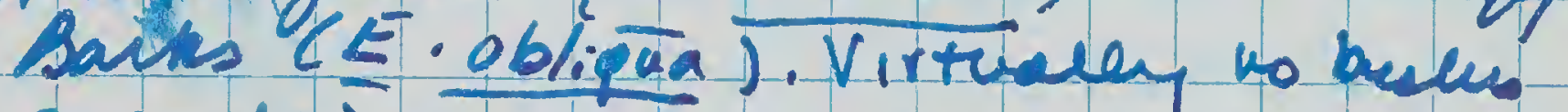
onseedeing in the us, which cunits

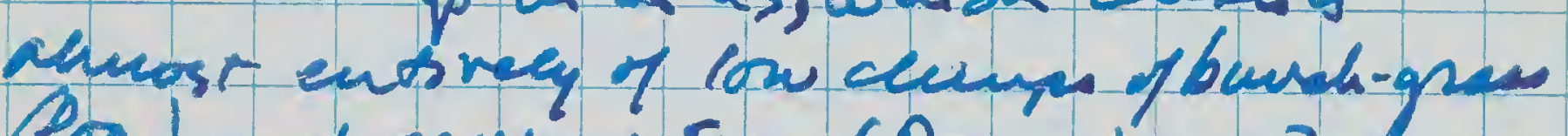
Pra) and scattored Ferus (PTevidicun?). Rel-bunned.

Trecuegan - mad olor with reddith nask medicen brom v. smaky bally,

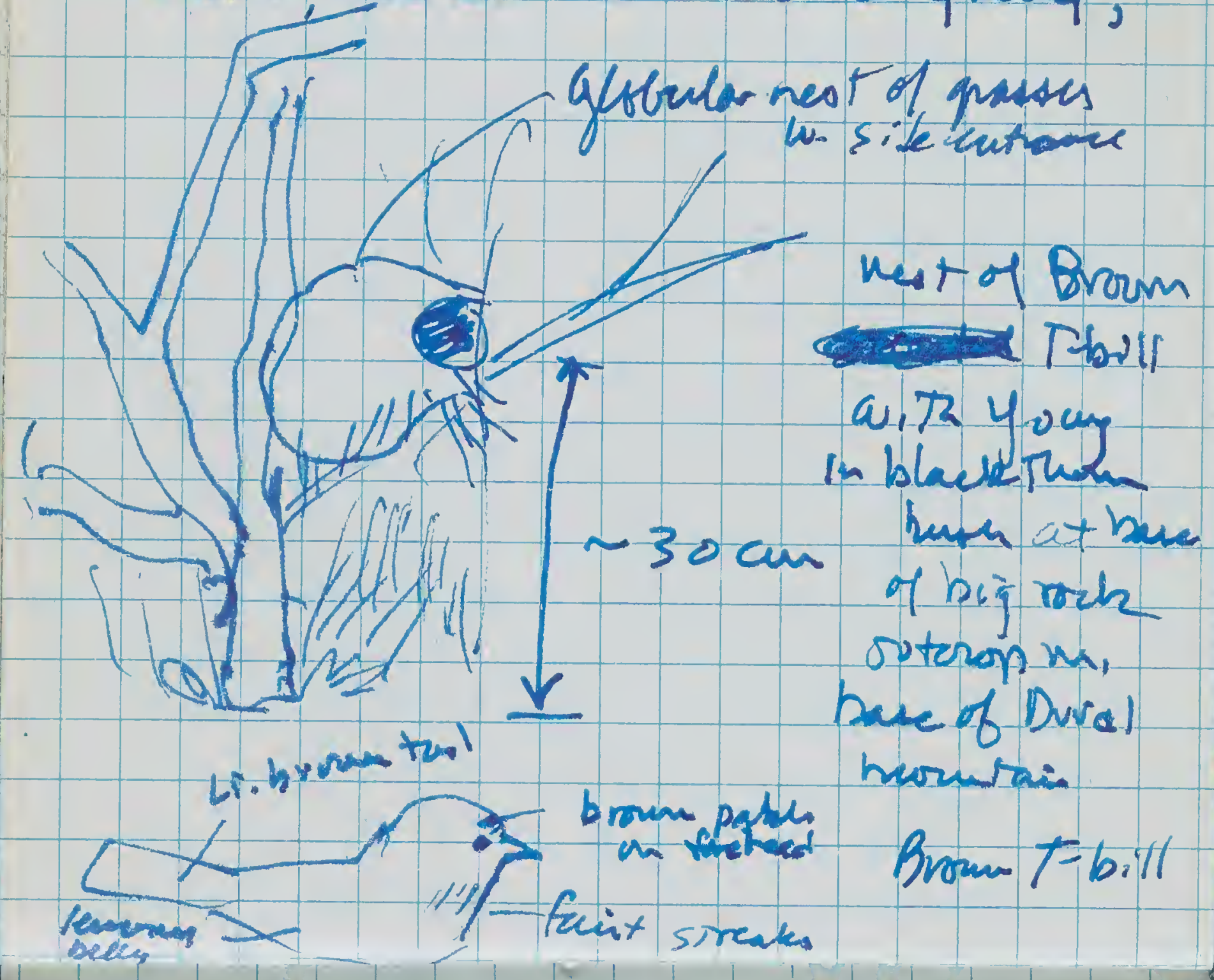

Imm Goldu whitler mEend loop of the E-W Mai! that neus Ust S. Sumuit MTDDuval (1) Ha upw. Aum diz. taig in gaum - 0.5 m to us ol quen leare

(2) $\sim 26 \mathrm{mup}$ in soming un glam ruig abre pach torg ( parang (stretrijupu.) $22 \mathrm{~m}$ up in $26 \mathrm{~m}$ striqy bavk

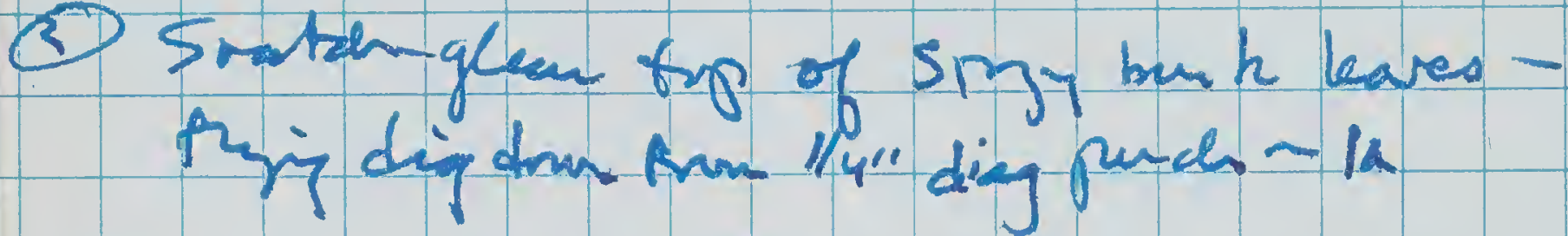
(4) gean buk of dig $4^{\prime \prime}$ linb-puch (4) $22 \mathrm{~m} \mathrm{uph} 28 \mathrm{ke}$ sirgi ibaith

(5) Hto up wito as of smy -b kef anter m. deng ly"ipeena im kelow 2 Qun up (6) Hz up ro us " . . . . $28 \mathrm{~m} \mathrm{up} \mathrm{in} 34 \mathrm{~m}$ smb bark

(bive flew $11+1$ usidn't re-locete it $\mathrm{m} / 2$ by. Seanch

Koala 5 m up in 2 striph-bark à same area (tree Plugged) 


\section{Wlibth sugutios (see topes}

IMnn Gooden $W$

20,1 \&. Rey wastra

2 inum Goldewa

ad $\rightarrow$ Rey. $w$

2 mim goldew Wh. (oue pusioterten chised a quey Shrike- Thusa)

F E. spive bill - probig mutebetlowas

$2 \% "$ " (chasing govion)

2 White-zuped Ht - devguj usderm and monin Mistle toe flavas

2 Wh mapt it "fesing on Mistle tre thren

Sulve warken $648-336 \sim 200 \mathrm{~m}$ SElast Golken olither that / dow furyjobs an rrume.)

$654-336$ - Som S. Wh.th Treecreepu meat site.

back to can or 13:00 ho 
Dumaresp Dam avea

14 Sept. 07ios overant winty ask

Austr. Grebe, Black Duck, Gr.teal, Galah, Red-Rumpus Panst, L.kookaburra, Avsre Covt, Euv. Starling, Nolisy winer, Reve, Weisten,

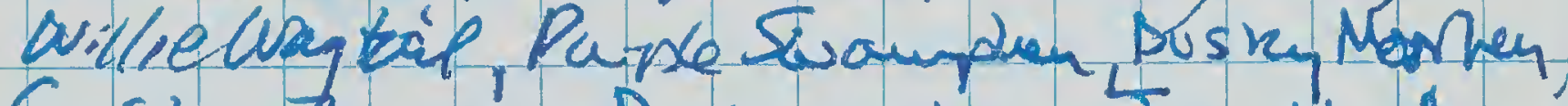

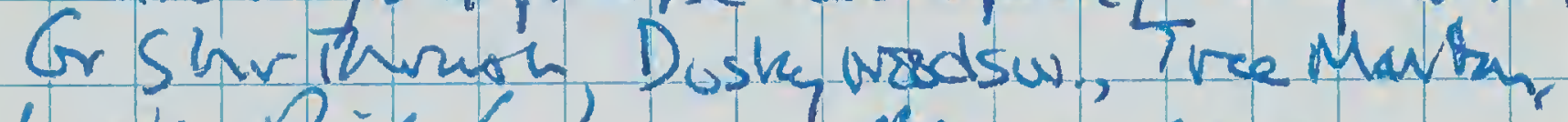
hi the Rhè Coriursut Magpic Lavk

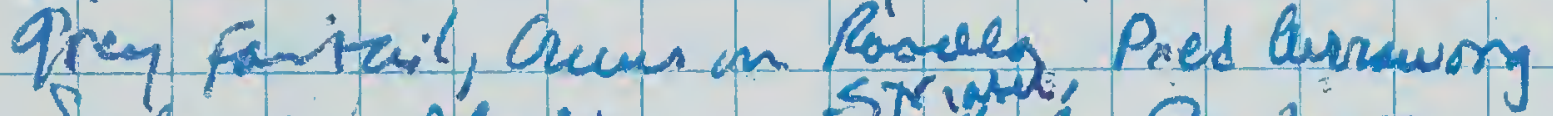

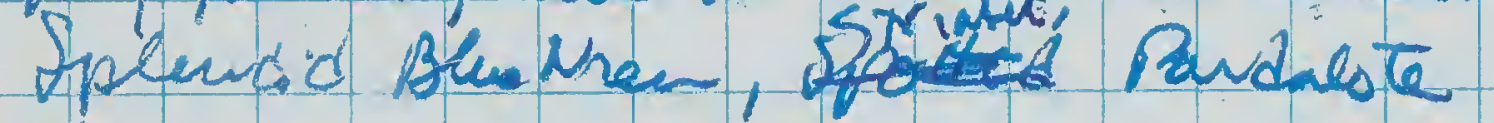

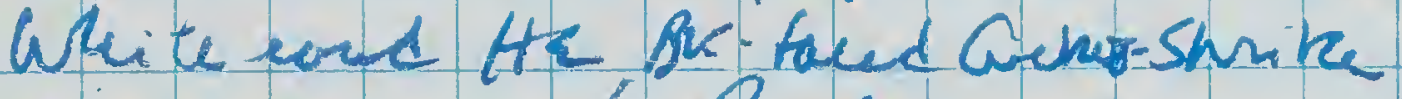
Br goshawk ra os Buff-rumed thill, Paven,

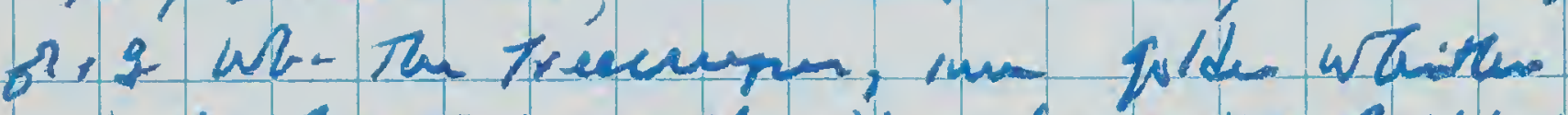

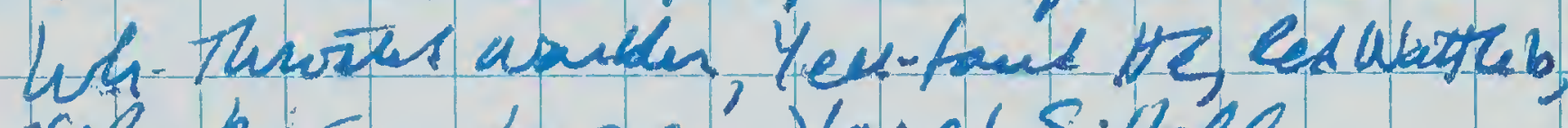
ah-brisumura Vavied Siftella E. Lorella, striated Th bill, wh- usped ty Brthembill, Y-T Back Colletro Bep- nnowed Treacuepar, 25 E. Spinebil Lis-pr. Fivetall (teuch), Bumbillsweh Wh-fand Herm welcome Awallow

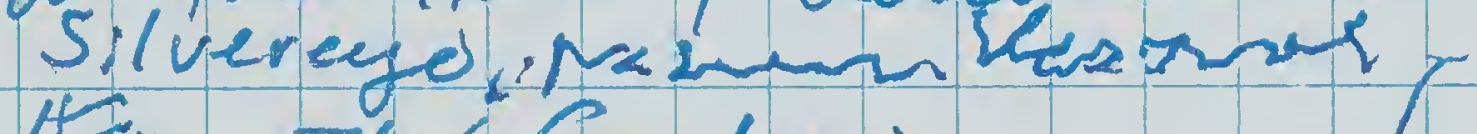
Fin- rile Cu now

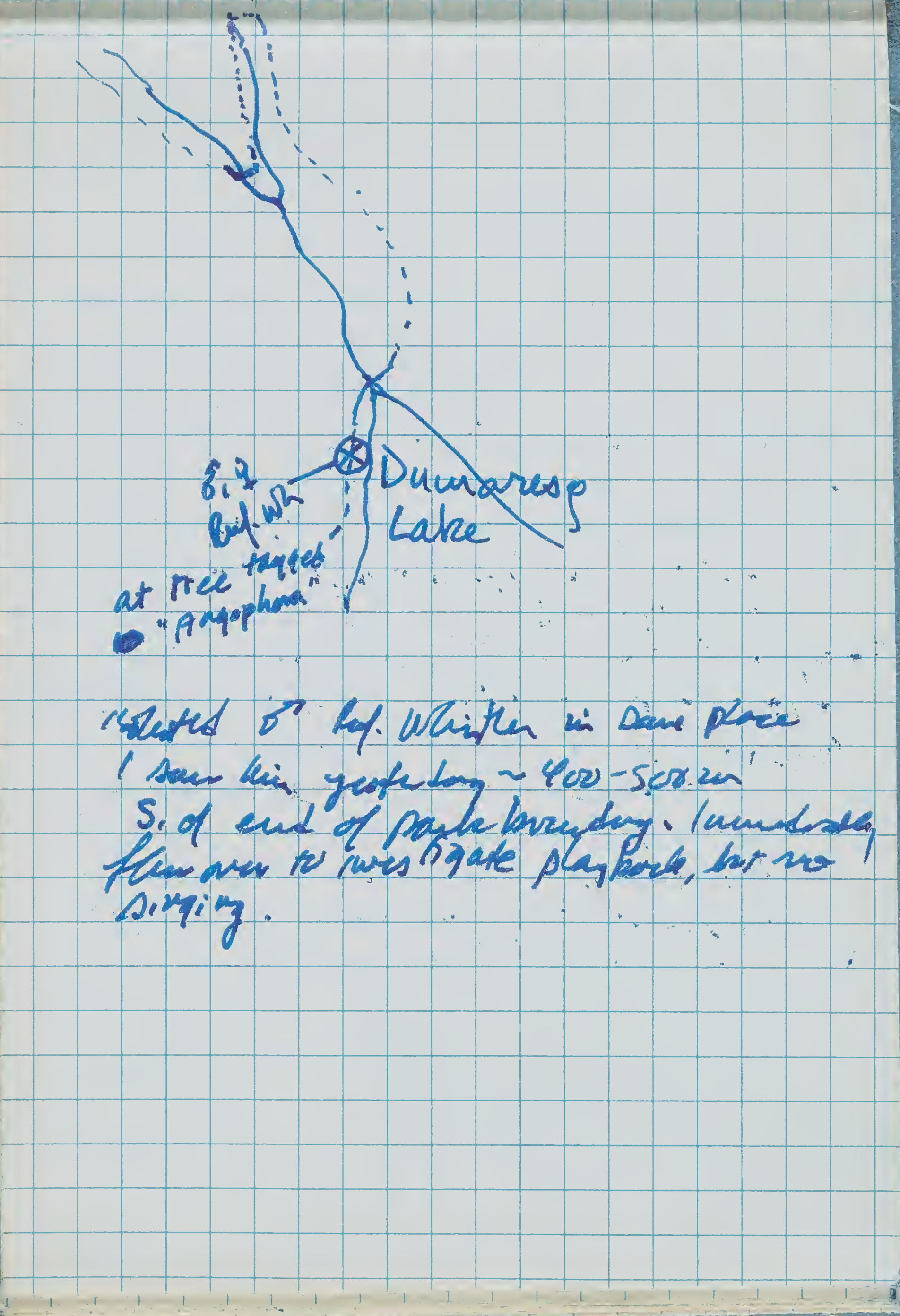


17 Sept Fair mild ch Sept. Dumaresp Dun aftimild dan

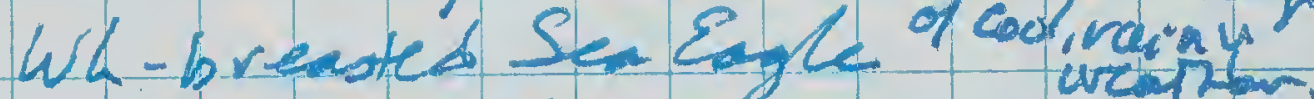
q 0700 . Word Duck, Black Duch Teae.

\& Acan. Cot, Moorneu, Bhubill (pr), L.Pres Cormoven S Shum brome Cuckoos Crizuren Rosella \$ Rk-f Cuchoo-shwhe, L. Kooskab urra

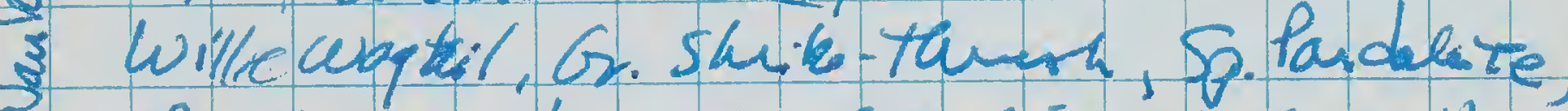
- Red cuarblar Eor. Starking wh-Tar Learbles

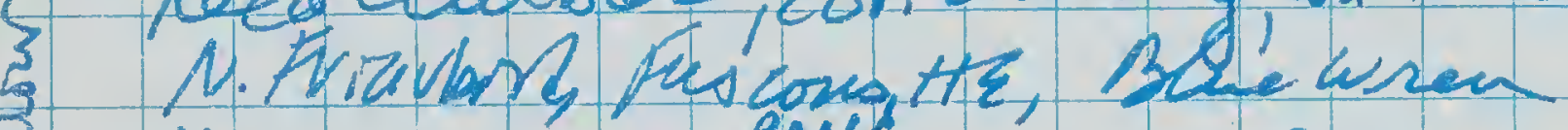

3 YplofitHE, Wh- Gr Fautail

3 Wh-eaded HE vackie W inter Buff-nuét S bistella king Panst Led Wattebird

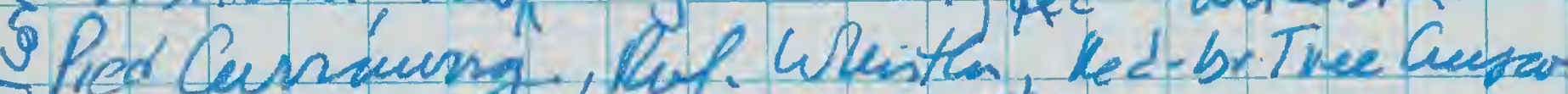

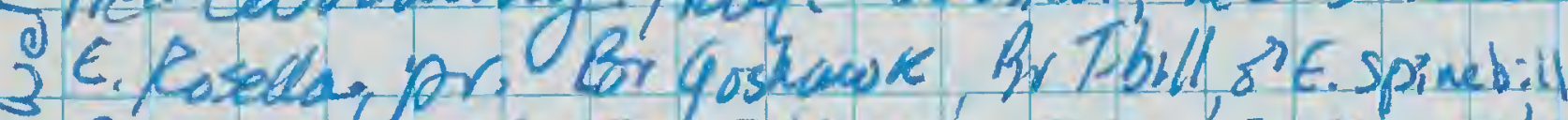

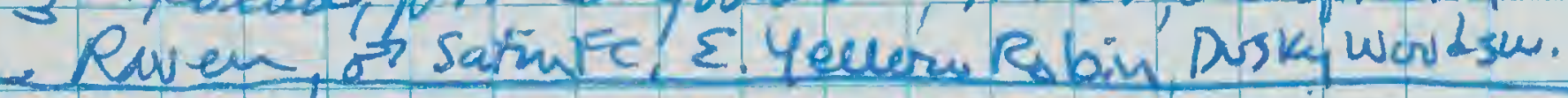

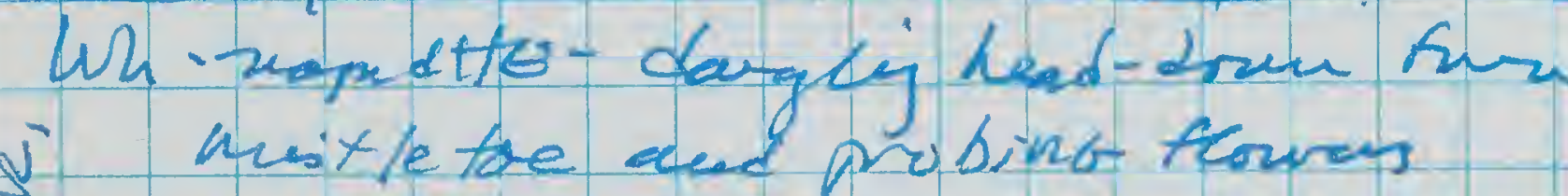

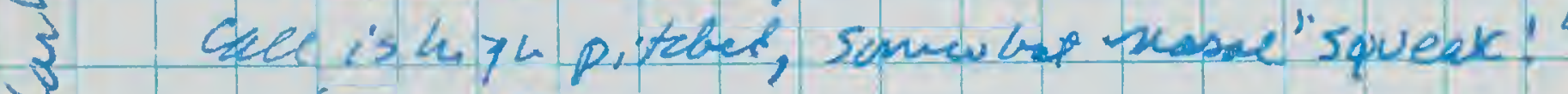
is (v.skort)

3 Kuy Parots - 277 and 57 ; Conge, heary kadied. Sit sbiffy, like a trogon. V.

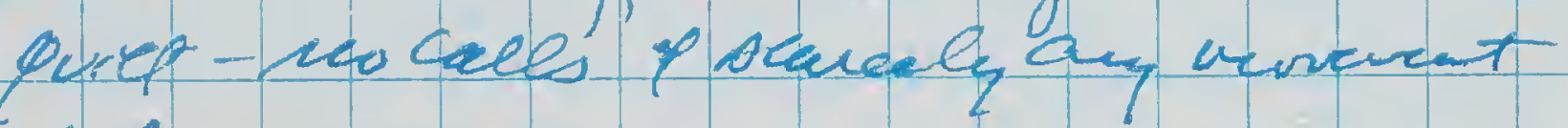
when puabed.

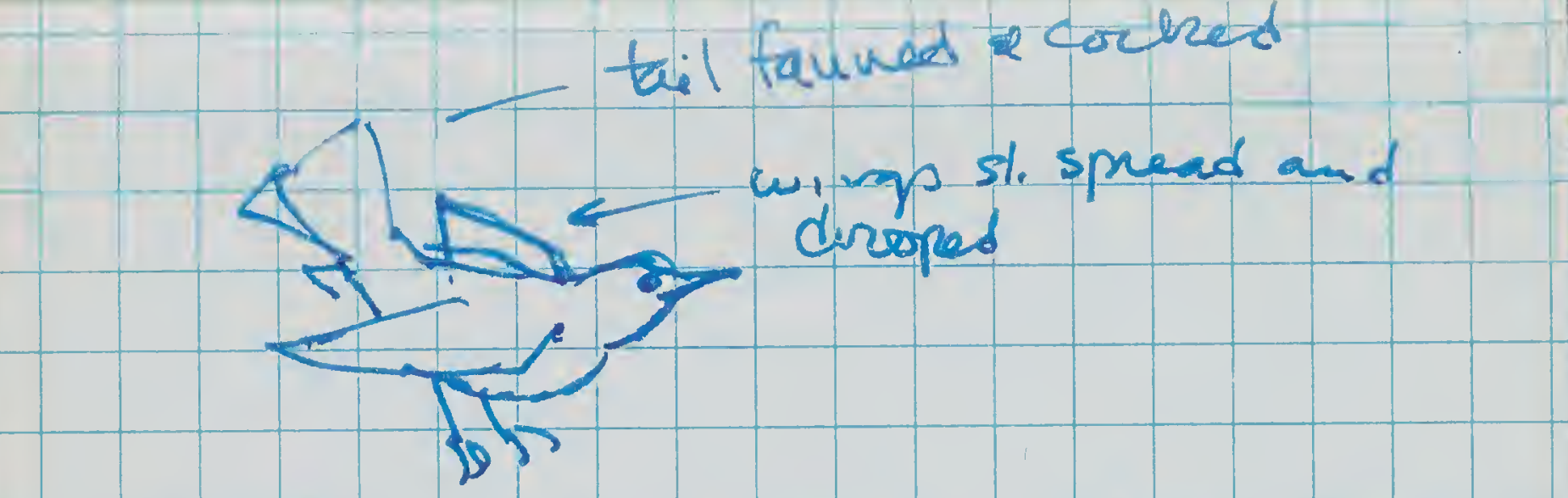

"Threat" dishlay quĩen ky 2 Reg whitcerff to exce oran, paddoet whes
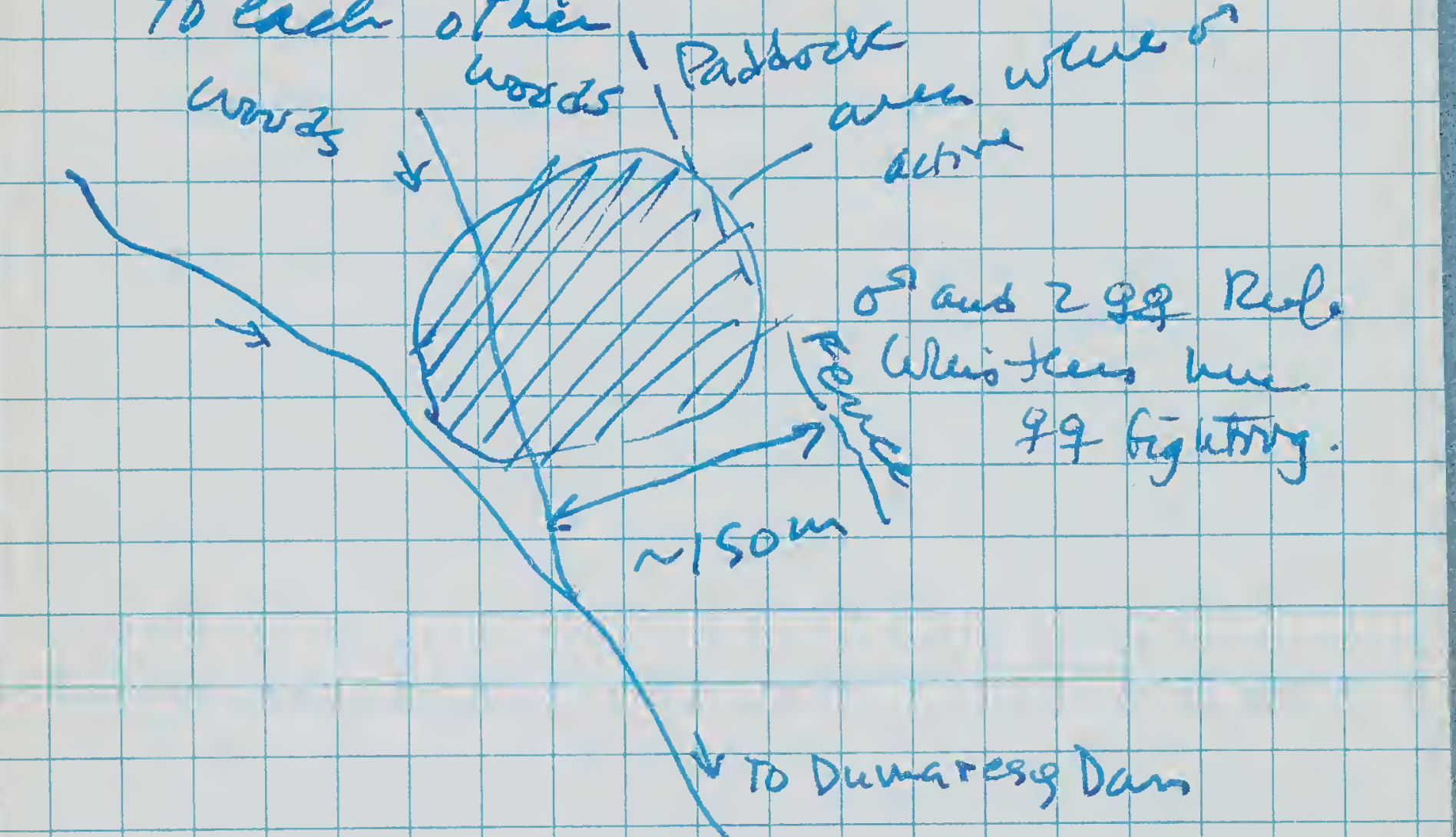

twice eq locked trogtur a piso whath aluost growend form 7-8 un $c_{p}$

1 Ellowed bordo E. to boundang fence Lor then, thea hend Wristlen Si across the paddock in the vest worlte ar nayfe. 1.50-200 m arey; 50, mayke Thes $\Rightarrow$ not settad on territory yet. 


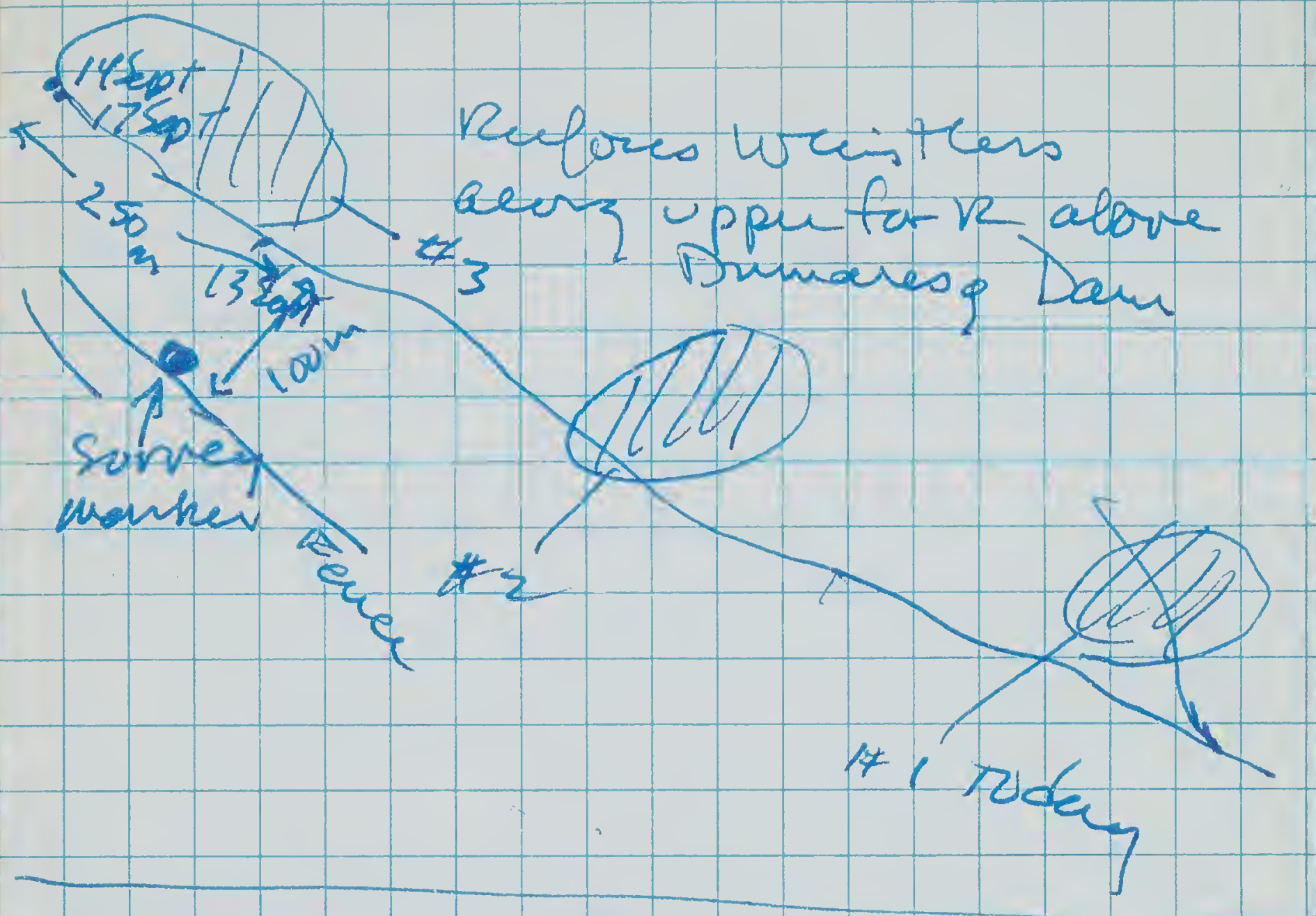

Sation Fleqativen (s) Iridiscent hlue Klack (like swollows) - vactive - Pliti aroud

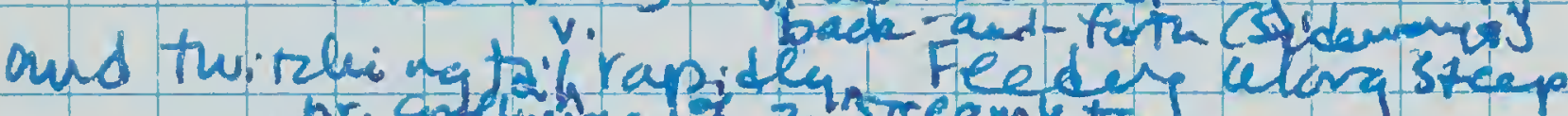

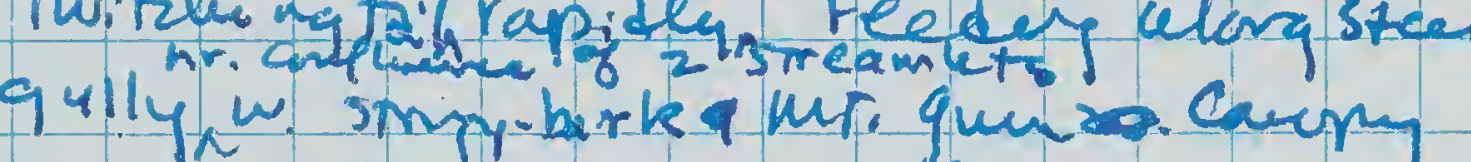
aud patzly deuce brash (blockthom, etz.) R. Hellow Rorsins? in same zues abo $\rightarrow$ Rufoma whisten.

Datin FC Saeured to be hour kif horag bea Thet wer feediy at a flowering shub $m$. the strean culs: hoarse puata ruaá aud higlur-pitched

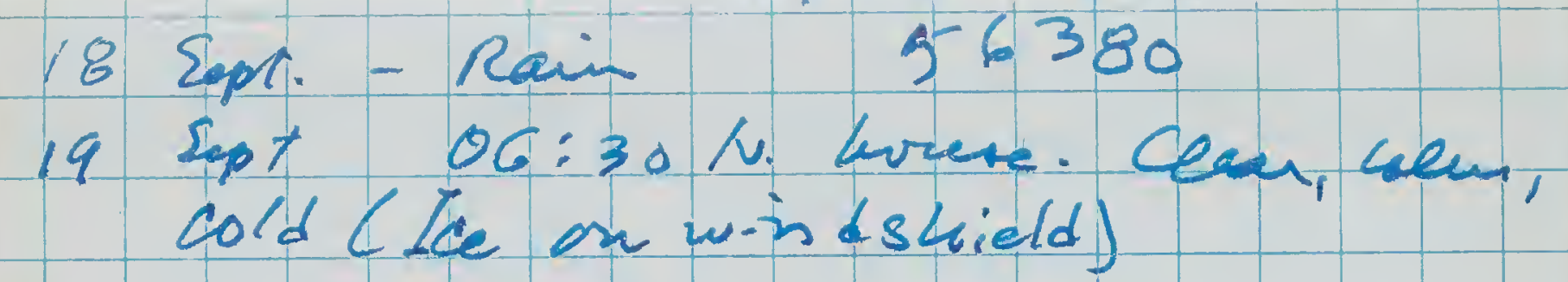
dove co on hu 78 foward Wollomomb. 10 - 6418.4 turnafy hug to Evilenembitass $07: 1076420.1$ wolcomombi parting area Bivds. Groy Shu-Thu, Red-gr Treeuneper, pr. Scuent

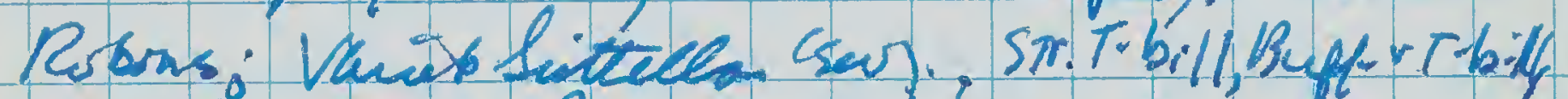
RedCunaung, Peregrime, Sh. bronge Eucko. Rup whittar, go iden wai the fo, Paidiése

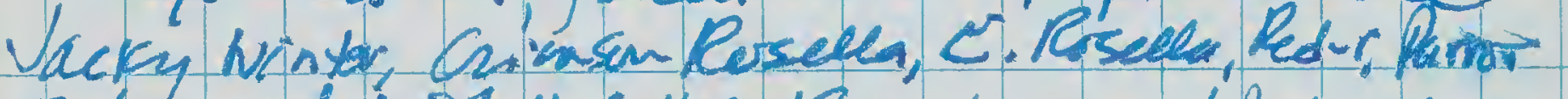

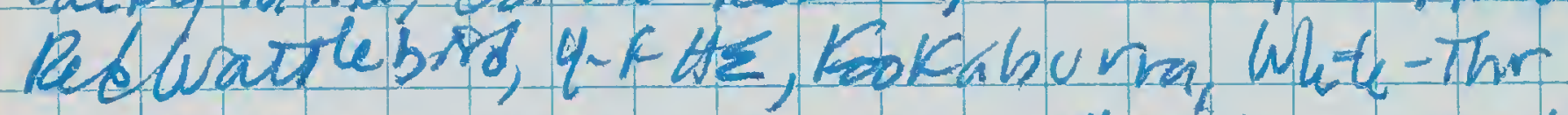
Tre eneyper, Brom Treecreypn, Maqpie, Niwagtail W-T Eagle, gr Fantail

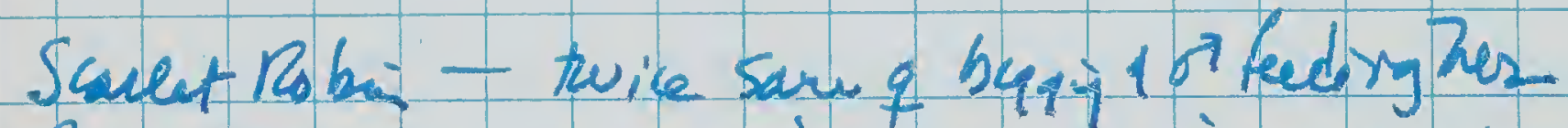
Reblar Theereype - peery and probing under lerre flobes of $94 \mathrm{~m}$ bark inum goiden wh. pr Ruf. whinisten (otar, \&) inum gulden pran. Whistlen Cacd,q] Dal wh. haurd NW of ridge $\leftarrow$ possinh Pupush or-Putip les e savebiva 


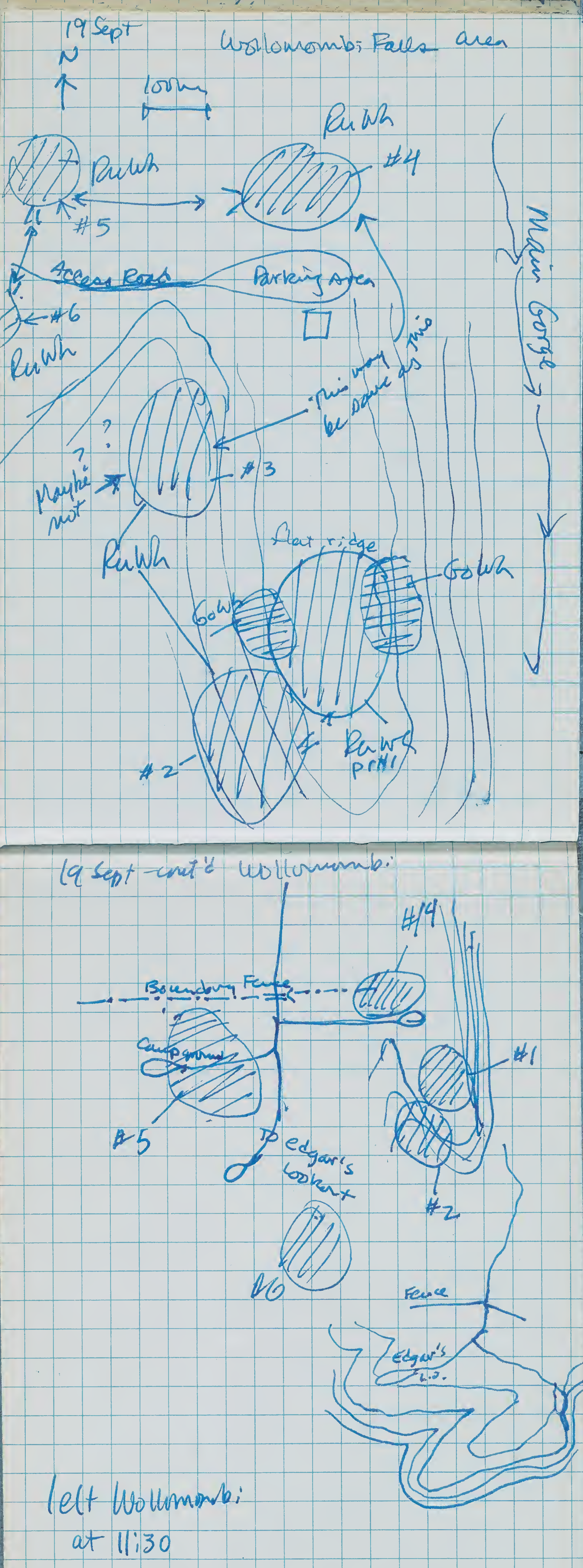


$11: 30$ left wollomemsi

$-56420.1$

- 451,2 rasupf lury to Troot Itakber (P. cookort is rew)

- 4560.8 "T"JCT- left A PT. Loukout 665.2 Banks;a Piñt Fa valey ara wache trails Arom 12:15-14:00

Comen Bnek Tukn, sas Pe Carraurng Raven, Sew Lewin's HE, New Atolloudt Es, $2 \Rightarrow 2$. spinebill, BRT-bill Gri Fantail Wh or Scruburen, w.TEgle, SatiuBruerbird hyrebrd, Cumsm Roseex

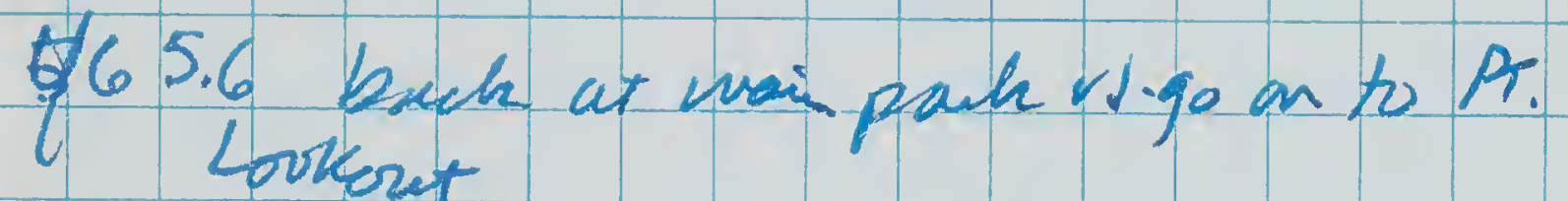
466.8 PT. loshut $\$ 588 \mathrm{~m}$ (NE Nat. Park is $29.881 \mathrm{ha}$ )

doue burkes - heath w. evergent white-buhed gums tor ism; sm dian-like mallee. V.ronaly usbirds hee erryt 2 W-T cogas sominaver valley (sear fren loskorty

1Y:20 tum back

46 le. 5
46 . 7 park at turnoff towright's kok out

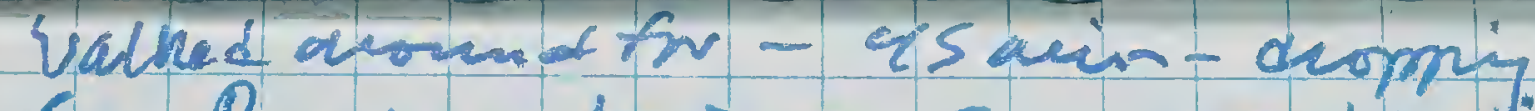
Aru Banks a deata wi Euc, orewotory wito Becch-brosder o 'ramport" not wary brvdo

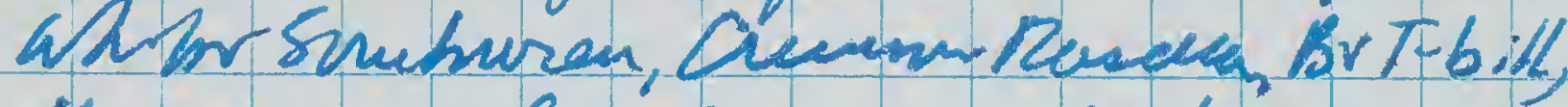
teard a colvita - rype cula cosple

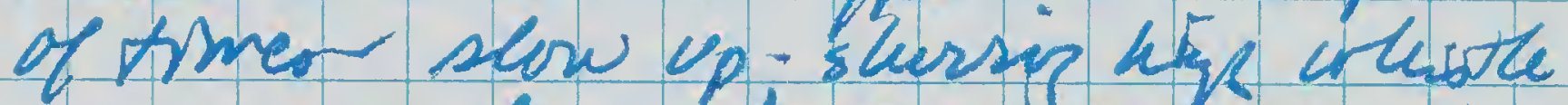
tounved by a shout, mel birer'ckno" weeel chow. qufautio

-6470.813 or Flave rbsis on govudie over paged orw pubture w. scabcul clumper of bunar gras. Nost traves

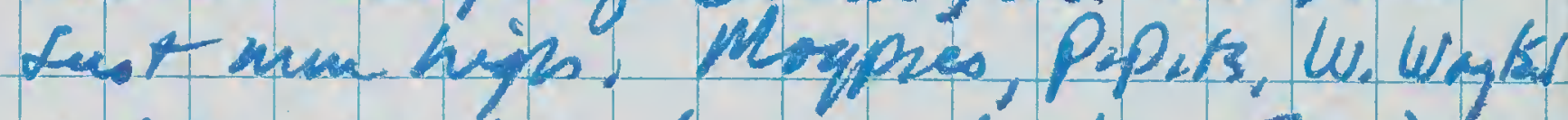
in save pasture (ave of $100 \times 50 \mathrm{~m}$ )

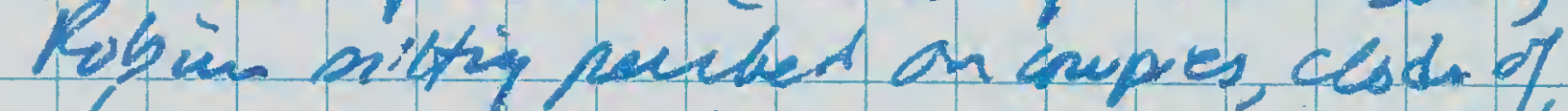
cur, et. - ales hoppij alorg like thu. Riknis Recleing at groud.

Guadually dendij up nire vorn, w.

shart swow slowess (sme tavid) Ba 15:00 anypletely overear. Ramikhif Started $\sim 15: 20$

- 6481.6 buek at hoz 75- pun w. no Hounde - (Hexvy hn !) 
2o Sept - Trip to Binna Burra, Qsld Ges - 29.75

-6566 L. at $06: 30$

Guyra - 604 (mother ef Ducks higom)

Teutapues - 6756.4 $08: 35$ Gas 110.02

breablest $: 8-25$ battcies 12.00 left 9:15

776 Gueusland burder

$$
\begin{aligned}
& q: 30 \\
& 873.9
\end{aligned}
$$

10:35 furne an RT. 15 Main Rauar wi ${ }^{2}$

920,8 Natl Parla PruícArea ll:is 11150 Crimsm Rosella, Sulf-or Cickator

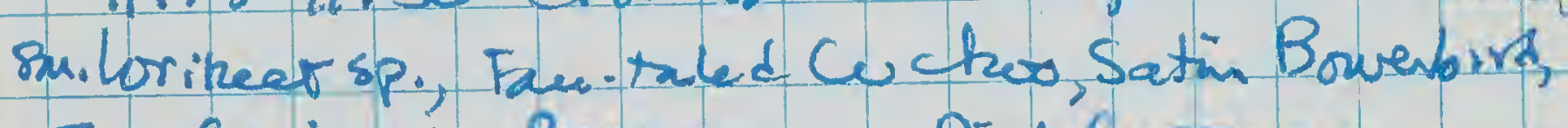
E. Whip bird, Beee Misur, Pres Curraury. Atustr. Raven

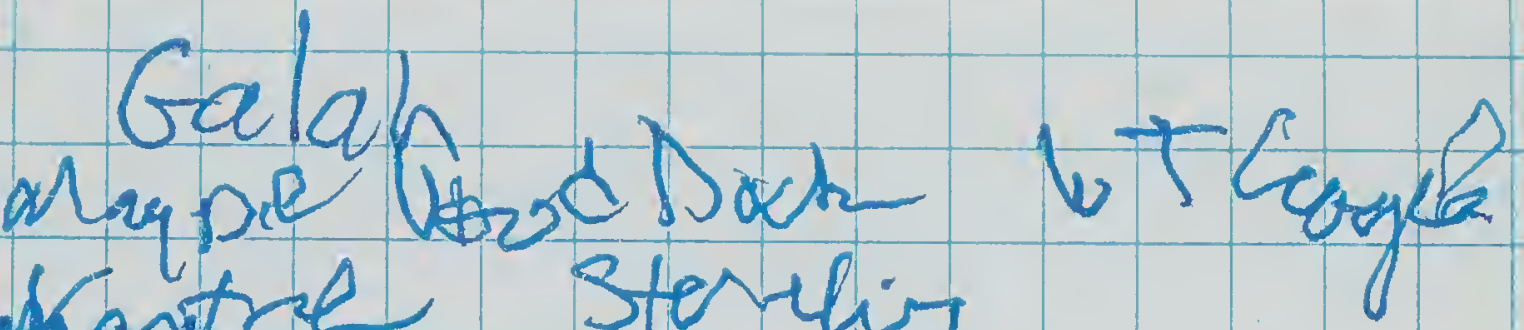
mostre stertir

marked Aldor Norisylusas

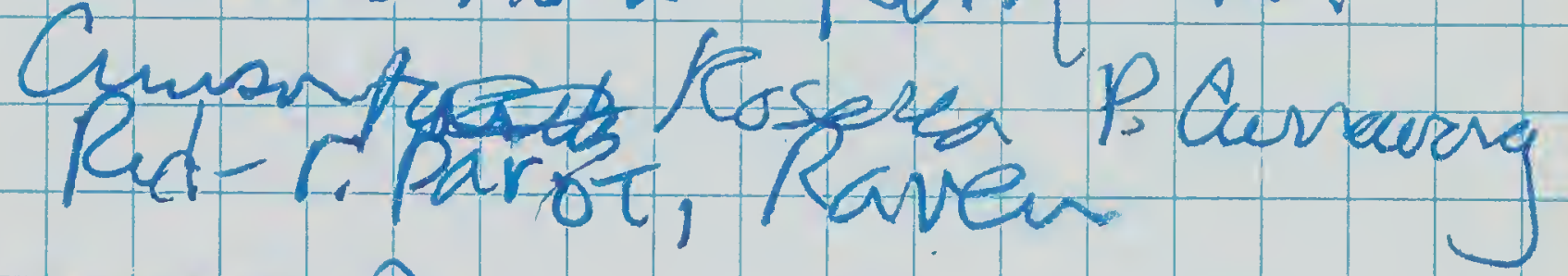

$$
\frac{10^{3}}{68^{4}} / \frac{1}{15^{8}}
$$

r4.90 Tomoft to Bequdesent 6947.3 1l:5s

6998. Beconden

1032 anungra

7060. Beana Burra Lodge

Laving gton, N.P. 
E. Whepbes-excavatij larare bole out of fallear lienb lyj arty harg $\sim 0.5$ m above foreot flear

Brdrat Lawrgton: Broun Prgean *

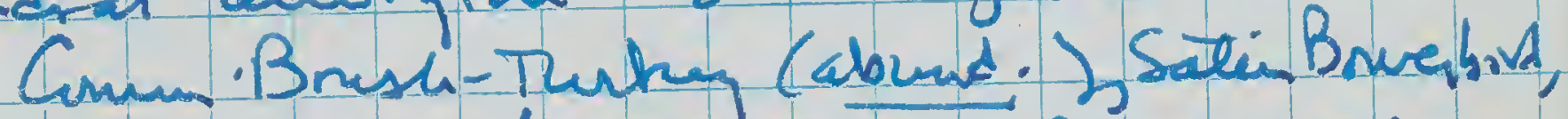
E Wupberd, Logranner *, Gr. Currawong', Crumm Roseeed, G. Fantail, BrT.bill Wh-bo somburem, Fait. Rilad Cuchoo, heewiris HE E. Sp.nebill, Grond Thush, RuFcres Fantai to O'Reilly's - Kng Parrot, Req ent Bowerb sid * 24 Sept 07:30 Cv. Buma Burra 57064.5

10:30 Gan orop Warmiche 18.75 -7252.3 Breatfert \& 7.50

lept at ro:3o aruve trmido 13:40

27 Sept Eastwoor State Foress

Dusky Woodswallow, Chongh, Moypie, Raven

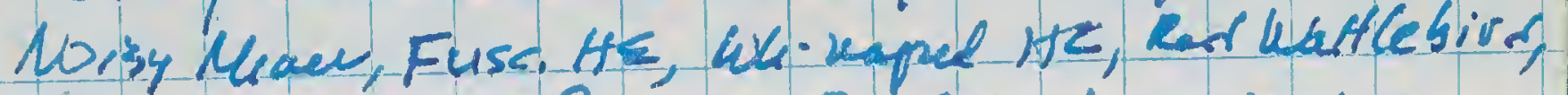
S.mobleve wren, E. Rosella. Bk-f Cuckow-Shrike,

Willie woytail I qrey Shuike-Thush Maypic-Lark Dollarbird, Yeeow Robin, Rul wratter, Burntreccleaper, oride fookaburva, SaundXingtizher, Grey Fanta':
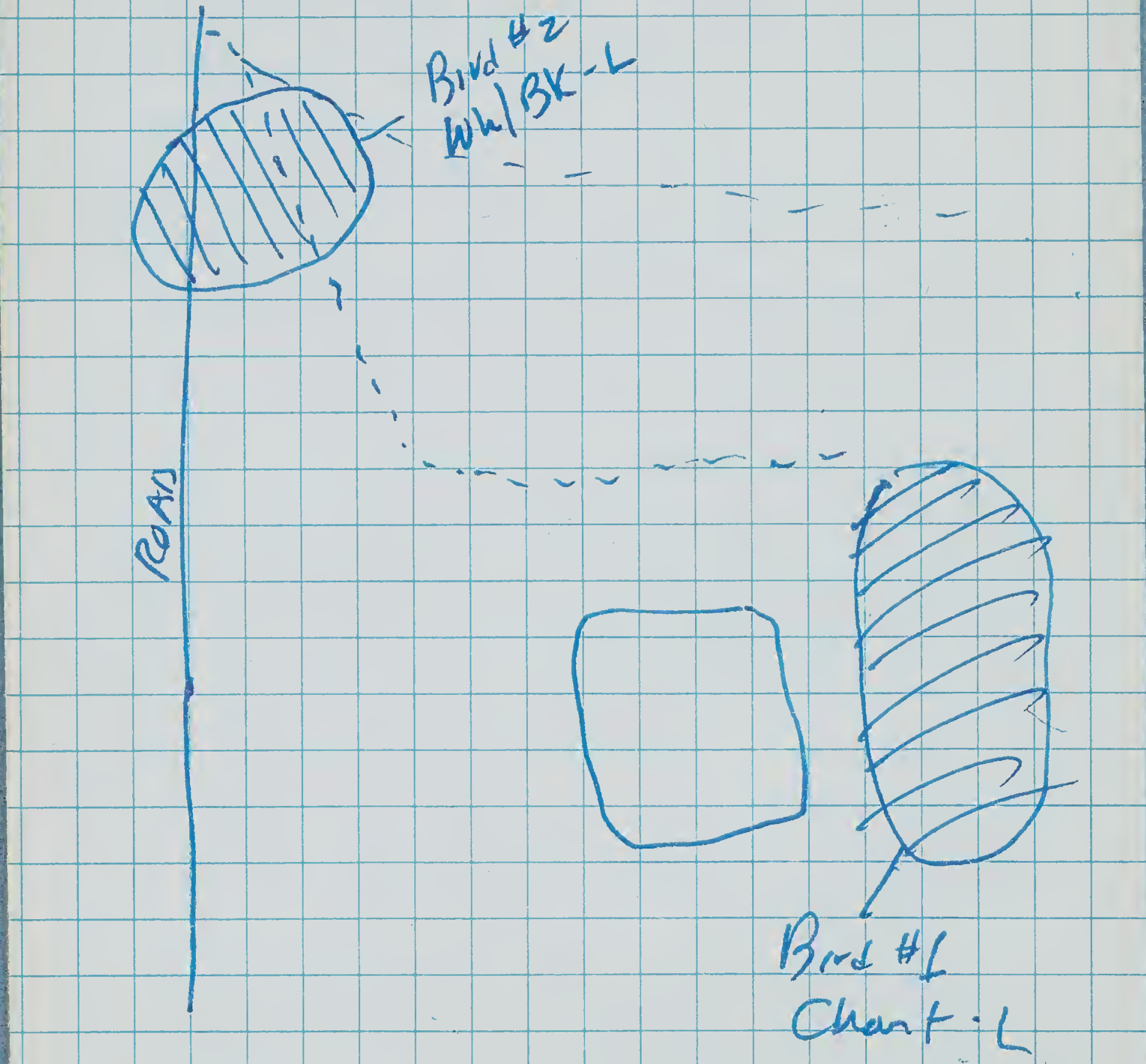
29 SepT - Dumaresg Dau t approchrd. obius Clested Pigem, E. Rocelea, Starlio por Naskad Plover, pu kenvabuna, W. Wagtail' Rof. Waisten. Noisy Mrker, Dollarlesto (pri), Eu.goldhuch Magpie, Austr. Wur Cromsen Rosiela, MagniáLark, Prqr Funtar7, Mraken Ar. Teal Bines:ll Ductz, Red Warbles AusNo, Grébe, 19her Duck (3). L. Piet Cormorent $\zeta$. Bunize cucros, Y. Foced te Bhe Wren

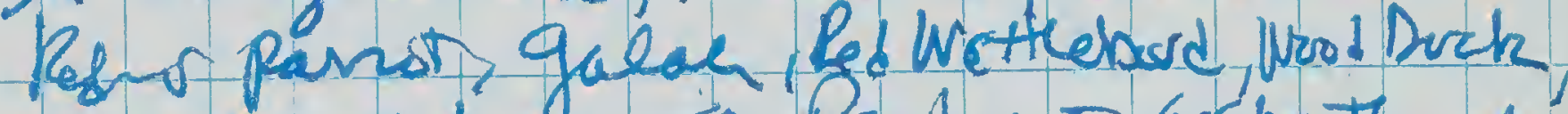
Buffir t-biff, Sin Pardalste, Grshr Tumoh, Whoth warbles, wh-eanad tts, We-naped tte Spepubveote, Satin FC, Red-br Treccreaper Dusky Lerodsue, Bk-f Cuckoo-Shike, Raven, Scaveet ko hin, golden weither, Ped Geenawong, br guskowk, wa-faed horen 4h-Ta treedeaper, $v$, sittelea Wh-brsunt-uren, Rey, whistler sugy in parbijurea no dam

inm or an 'Ruchy Ritie'-aceoss brige at top or L. Dumaresp (*')

ad $\rightarrow \rightarrow$ Yoo un furthen up drainoge (\$2)

atove Whe on N. Sida of strem

$\$$ shrued up ofter $225 \mathrm{~min}(\# 3)$ (2) $2 q^{660-332 \text { (150m NE }}$

iq

if

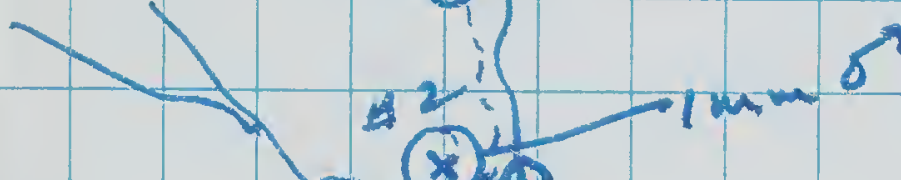

Wh-mand HE- hash, vires-like rasping ale 
$6 \cdot 666-338$

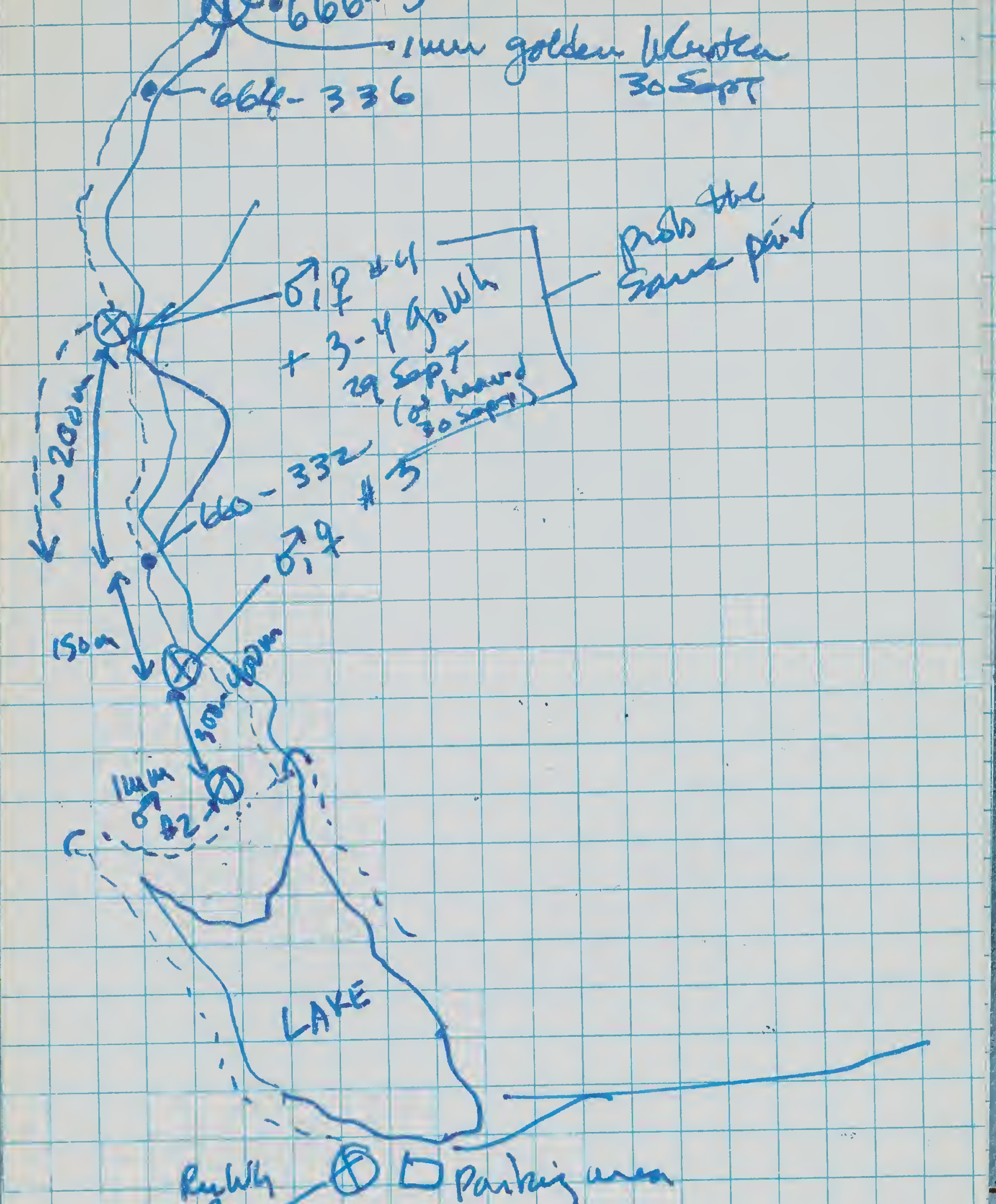

\section{* 1}

Ruwh

$29,30 \operatorname{sept}$

30 Sept Duwares (1) Reb.r Parrot "Crumson Resella (3) galsh (4)/tusir. Cout (5) C. Gorimule (6) qreyted (2) wod Duck

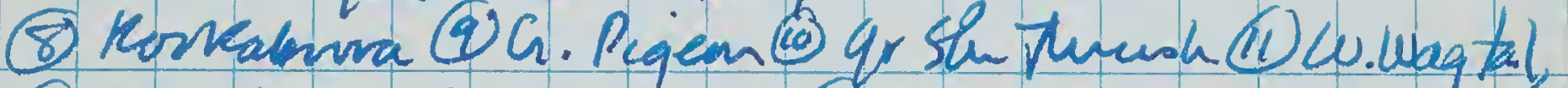

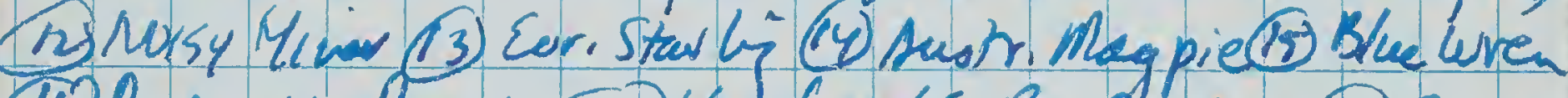
(16) Rideand's Pipit (17) Br. Cor kov (15) Sittela

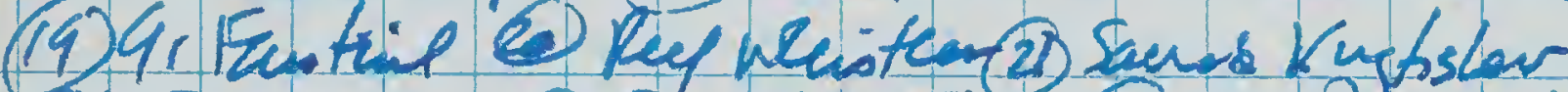
122). Rosella (25) Tree-Martim (24) 57 . Pasdals te 25) Dolarbird (6)BufforT-bill 27) Y.tand HE

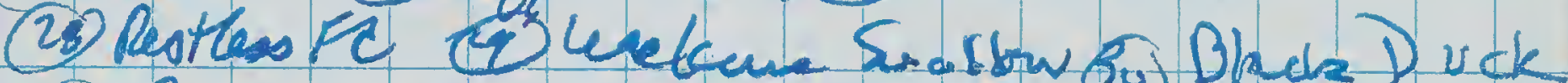
(31) Reed warblen (32) h. Prid Conurant (33) Aus sr. Grebe

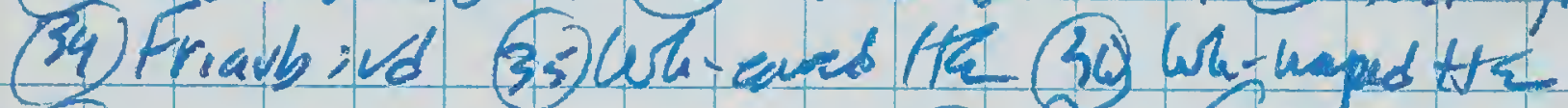
37) Wh-TwrTree-cumer 38) Hed Currauma (39) Scaslet Tobin (pr.) (40) STr. T.0.:2 4i) BrT-bill (12) 9olden Weatar (43) Wh b owed Emburem.

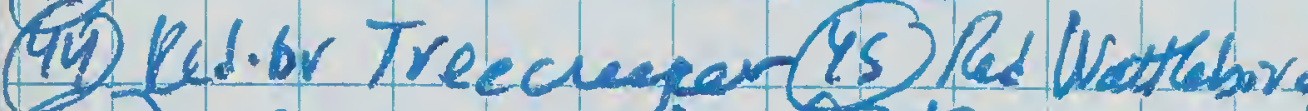
46. Wa. Tar wariblea 47) Raven. (4) Brqoshouk (19) E. Spivebillor

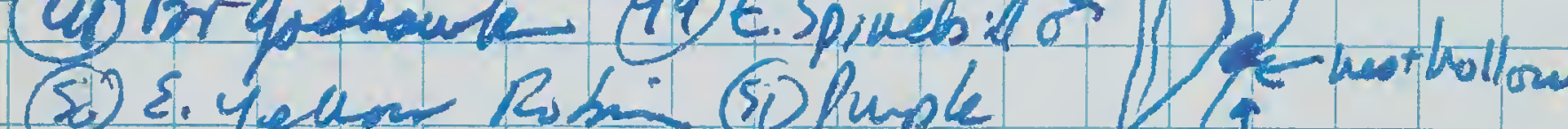

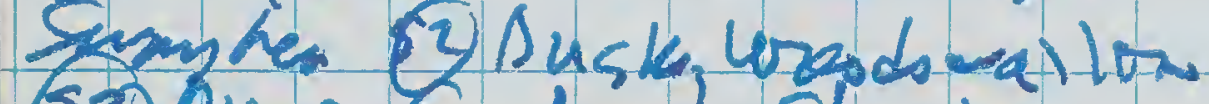
(53) BK-K Cuchor-Shr.k

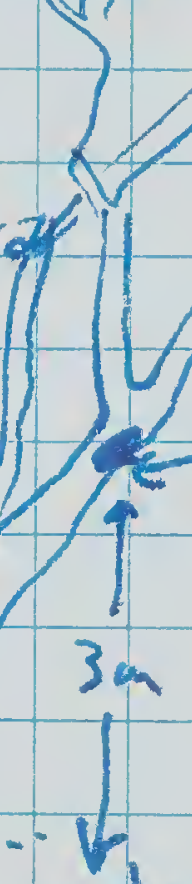

Wh-iur. Tree heupur feudin youn in rest buit inside gow hollow $3 \mathrm{~m}$ abore growe in flodplain on w. Side Dumaresg. G. above llte (Wh flap plaued 20 NE) 
pi. of Ref. whistless on loswen seren nut.

Duval OS ben w. freed station Cnr. Sunvey pr 684-342.

Sere Debus - Ceusuad brrds Sunve I Date Whiters? 4

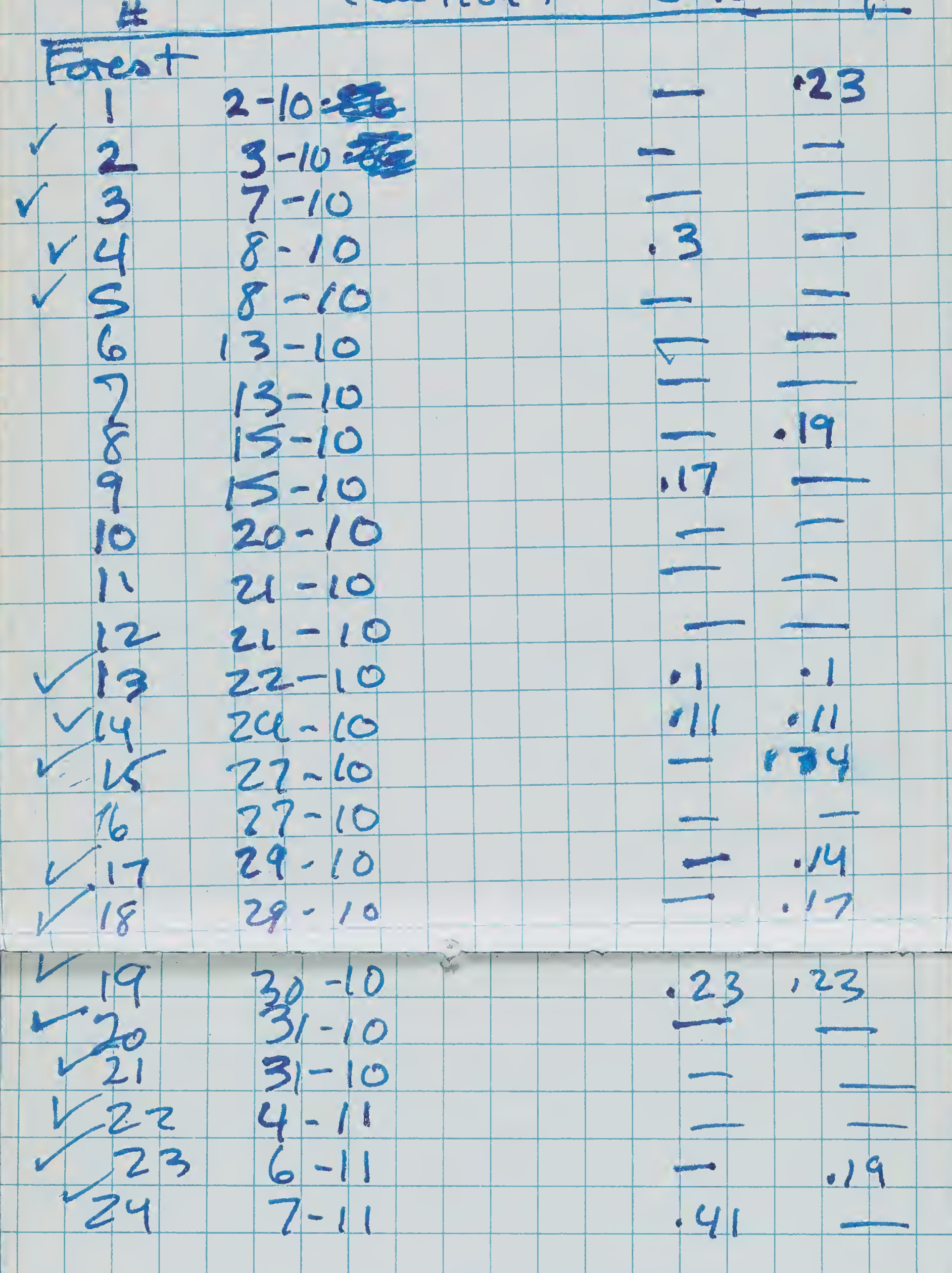

mean Trauseat byth $1192 \mathrm{~m}$

boodlaul

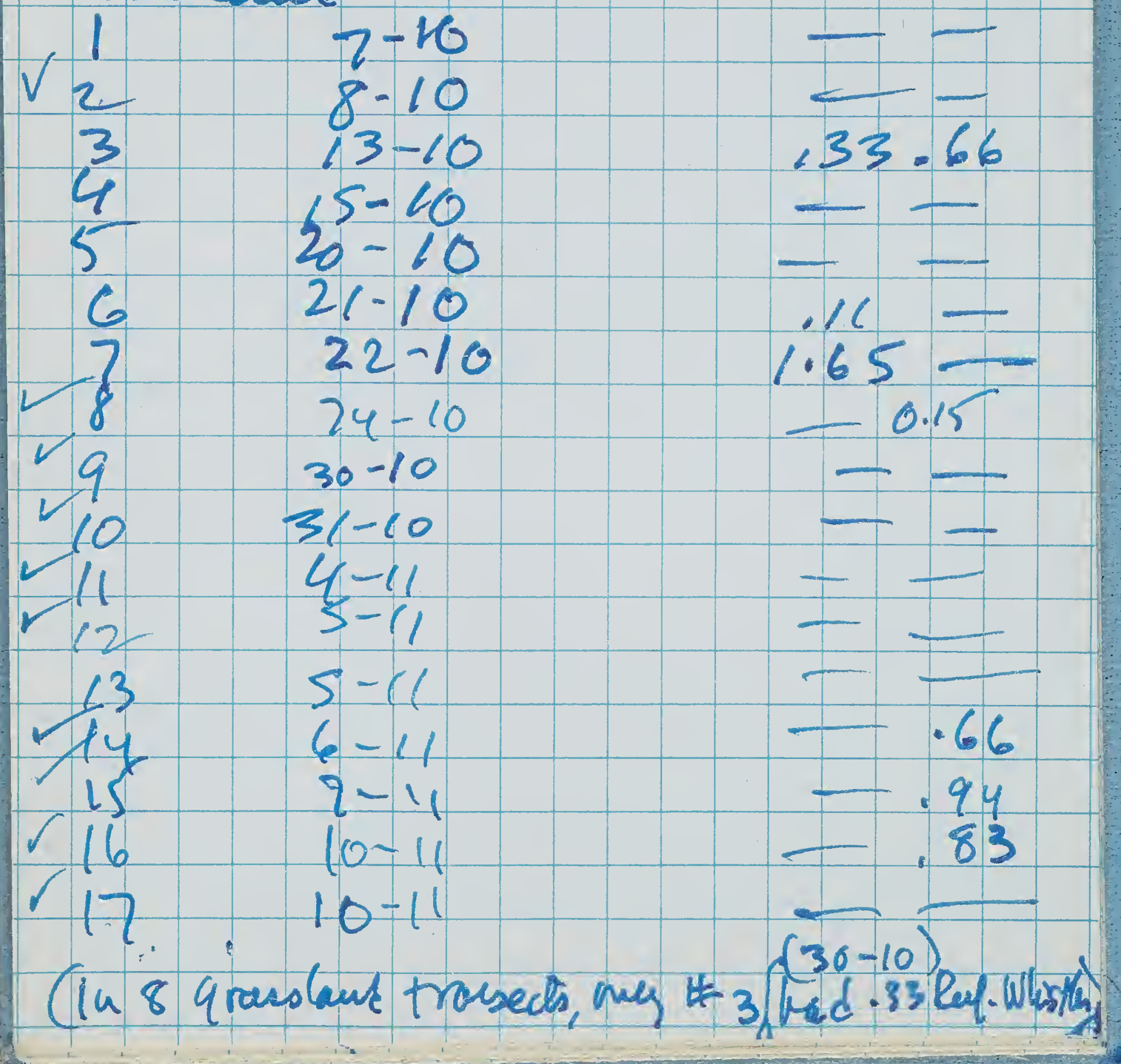


Wutar cewareses

$$
\text { (cher-tuly } 2886 \text { ) }
$$

no Defores wleitless atan

Golden Whitens in \#

Foret

$1,4,5,6,11,12,14,16,18,19,20,21$,

$22,23,24$ (manyingorps)

wodland $4,4,6,9,11,12$

apastand-nose

2 04 88 Wollomenb. 57ate Pawk 7iostan Fovgij date an prs of Rif Whitcens (taped) heoud sav. OTew Kuf. Wh - Mo golduns teen ar heard.

OTher bird: Kooksurra, Crimsen Rosulea, Sourd Kinghisher, Wh-Thu Freecuepur, Rd-bured Treaveeper, gr Shrike-Thurath, SatinFC, Vavied Sittella, Flawe Rs bin, Buy -rumped $T-b$; ll, Red Carrawong spechled Warblur, STr. Pendabte

57744.9

NE R.P." Olive wais the 12 ) thalle found alve tive id to wrights lookert $~$ $1.5 \mathrm{Km}$ S. parkiz rea.

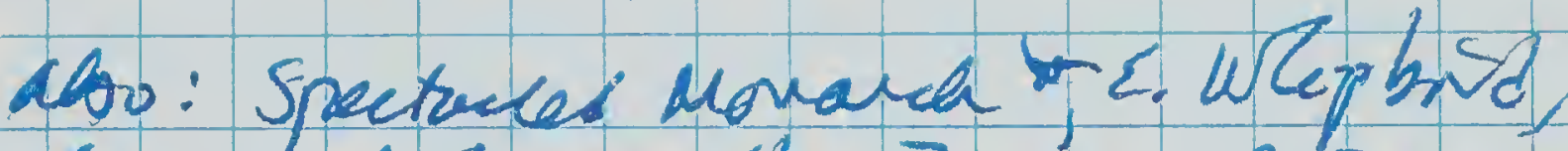
Goiden alester, q Shr Mruoh, BrT.bill,

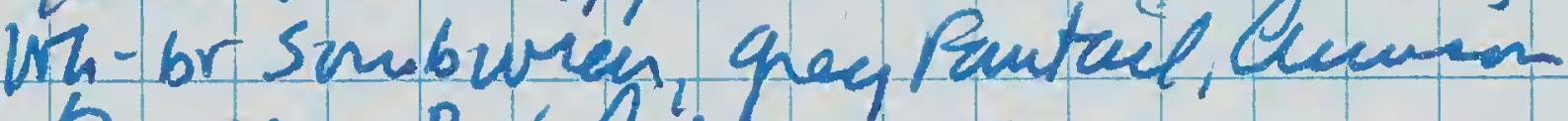
Rasule, Ped cirrawong

left are at 12:50

747.1 veT. STYX N.E. Vd.

766.6 stop uniz looperd at aceb cusaj Fonjitata on o" q Regen whirtes?

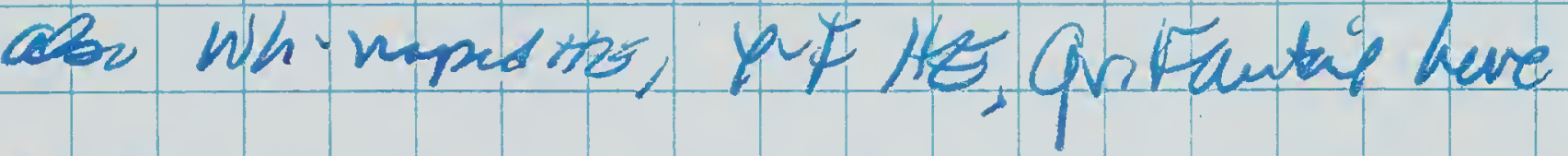
762.0 der looptes $X$ sxy $+R$. Fonstrod.

7113.4 se mainrd out to hy 
30488 Neer England Nat. Pawi 08:00

Bouskia PT-Weepiy Rocle area

Autarsiz Beech ("Nizgerkas Beech") 08iss Nothofagus moore:

934.2 Wright's Lookowt partiparea 12:30- back at lar - Sow or keand weg 2 Orve uraithen $t \sim 4$ prs. of Gobder waintlens (t 2 grsur Tur)

Aothebuel esch N.P. - heavd, fre.chite - dey Euacupt uors de 79979

Deer Vale Rd - pr. G. Idu ventus ir huy (Got sonetany dota) tan reunat 7 wetsclerydy to sat Er culipbord, a

inu vicn Rew vace ns. anom pr of gizlen veribtas (t one in distany a corple of terigy olas.

YOCT Enstwod state E-cot Cleavi warm, calem ierc condetions

Sout Sizo Trip to Beech Forest 8137 w. Havry R. and EhisabethD.

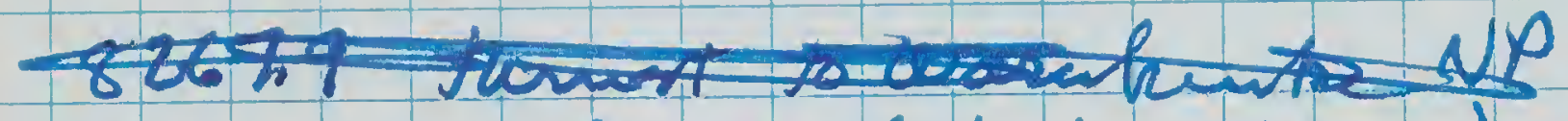

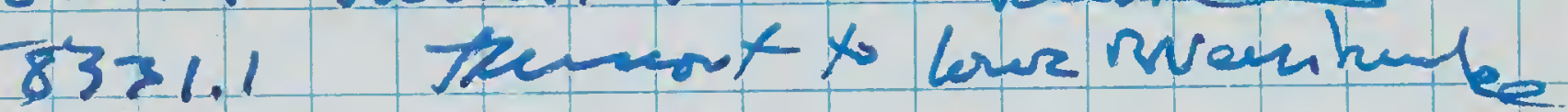

8348,2 S4. Cockera wombecba) Rd back to Jet. 8053.8

83568 C

8375.2 Beech Platan Ricuri wen 5 prs. of dive whistm locatied betwen 10:0 and 44: 30, hat seneart ileprasibes

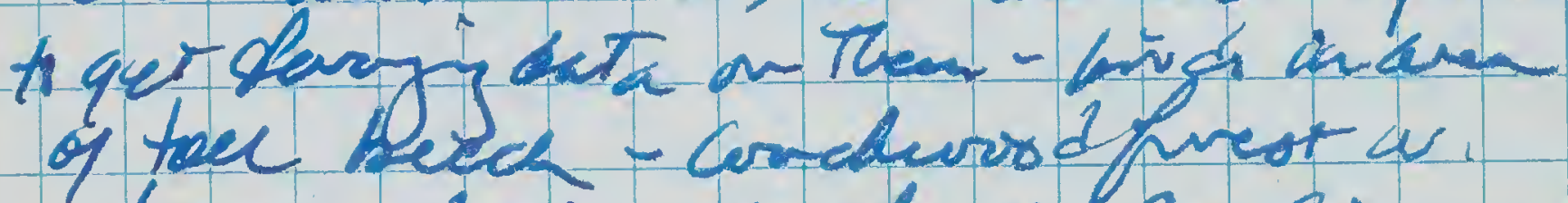
dense undenfin of slumbs, saplinpete. Vay sey, and twres haep ont of keg-

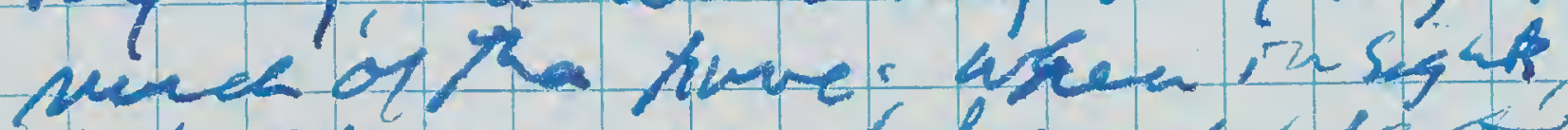
bin's aluost mever frieged 1 Igot vey ( obs:)

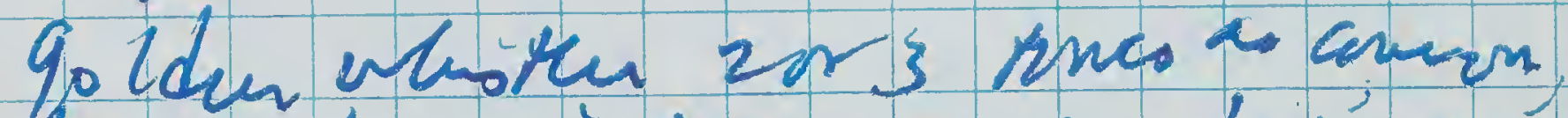
hut v. high nistres, $q$ also defients toweth fung Broum wiv

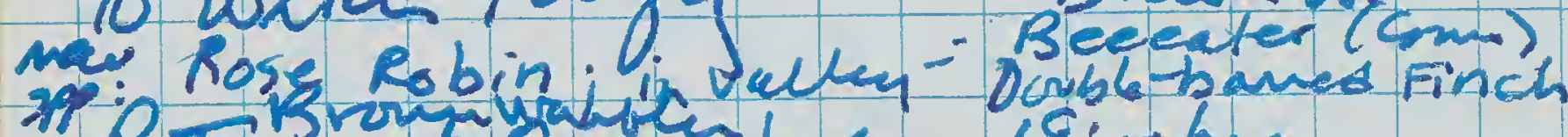
Reterm to sumidale 18:00 hs

-8592 . $\frac{139}{155}=455 \mathrm{~km}$. 455 


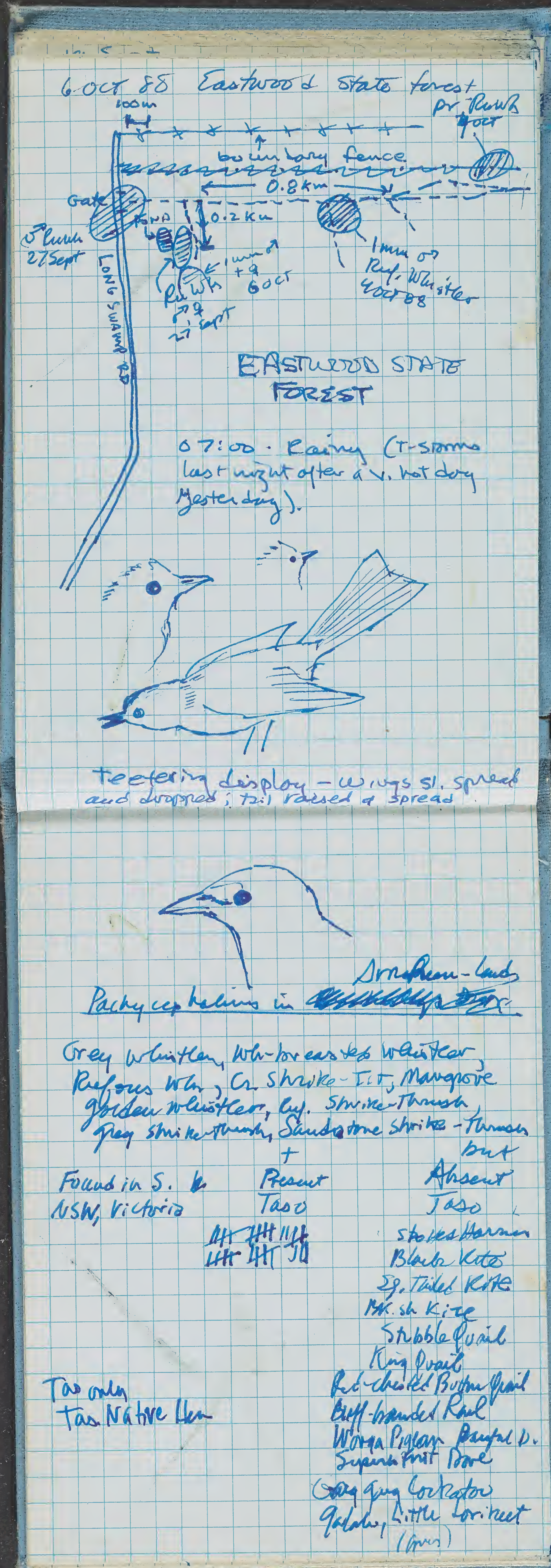


presut 5. Cont

Ser. Taso: Kug Ranot Red-r panst

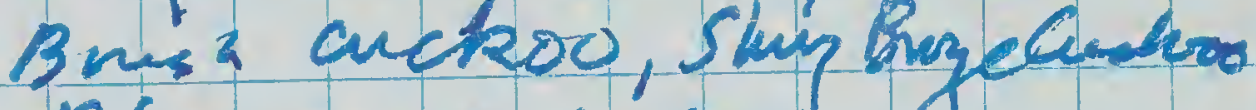
Blun-eare Cuko.

Ranisbor Beenta, Dolavina, Eory nut,

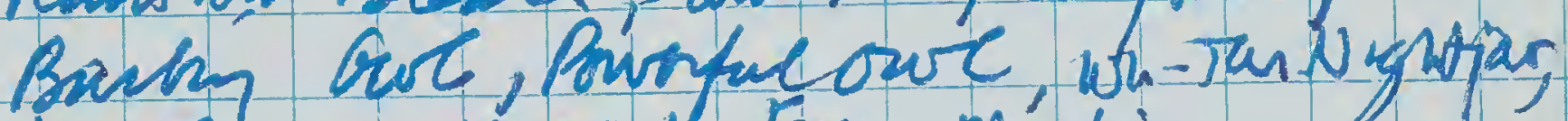
Hol necdetail Fairy Mutio

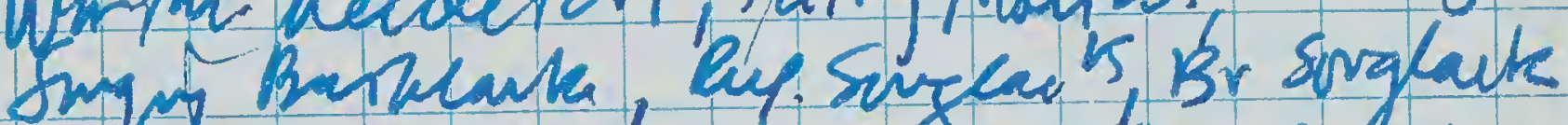
whtecuchoo-shrike wwhued Tribr, Gabbra

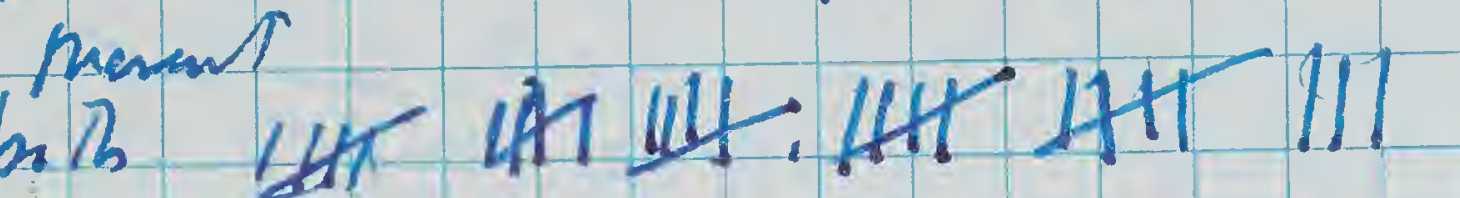

Hoar Ramm, R.C Rabm, Hoded Re bui Eyeeros Rom, Jockeq uninter, Shri zén Puf. whister

Ebave ro Taso. Dusty Rou Thorge Prebugatvalinas

7 ocr 88 Easturd Sith Fired

6:15. clewr, cod (host las mizht), culm

- re grey kajanoss m. Gate

abo aur 2 Euros a Swamp Walkby

ktex in mormig (t more greys)

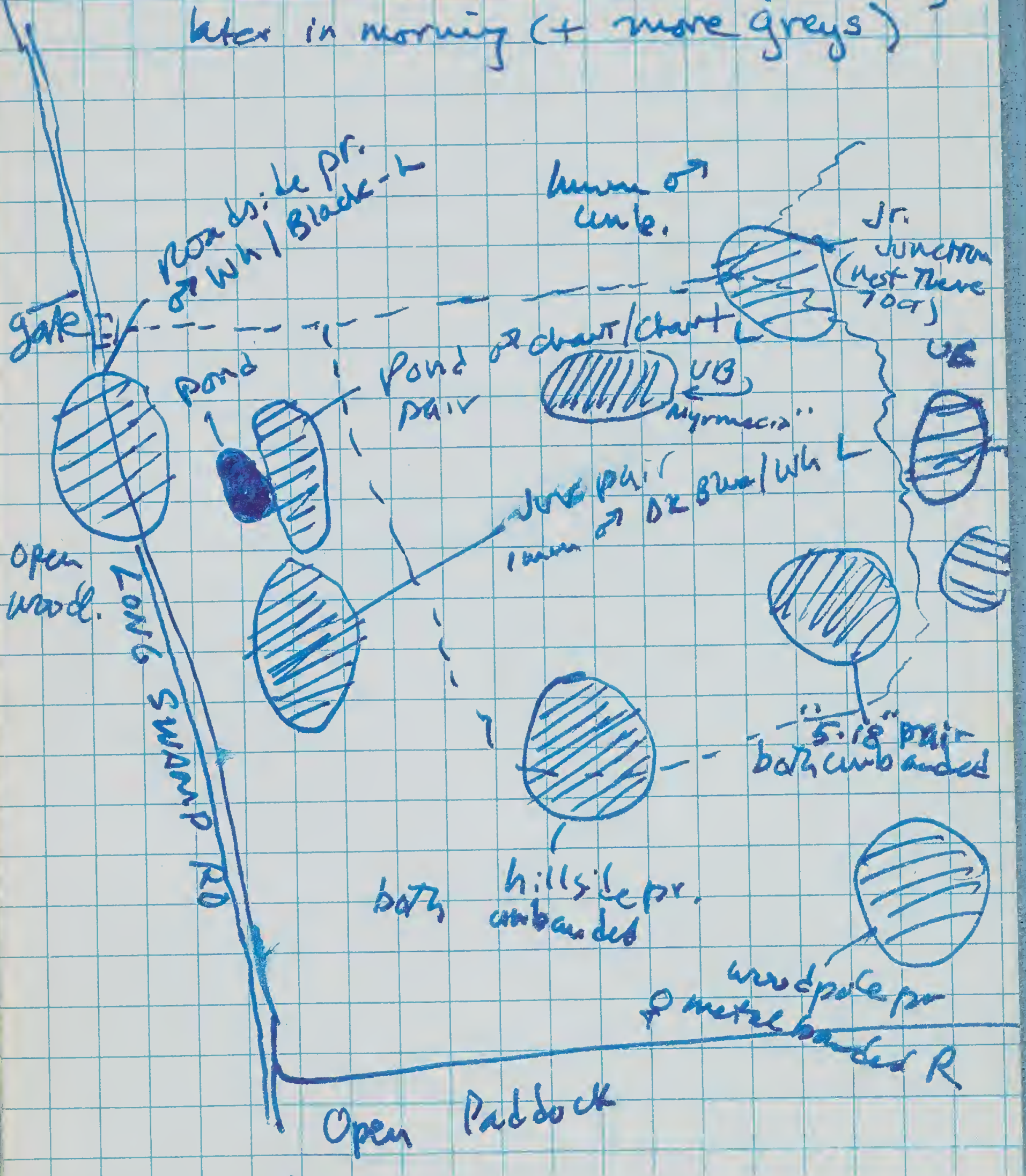


80ct. Wollimamb. Fales Trip Lr. 0600 $\mathrm{plc}$, core, calm

58671.1

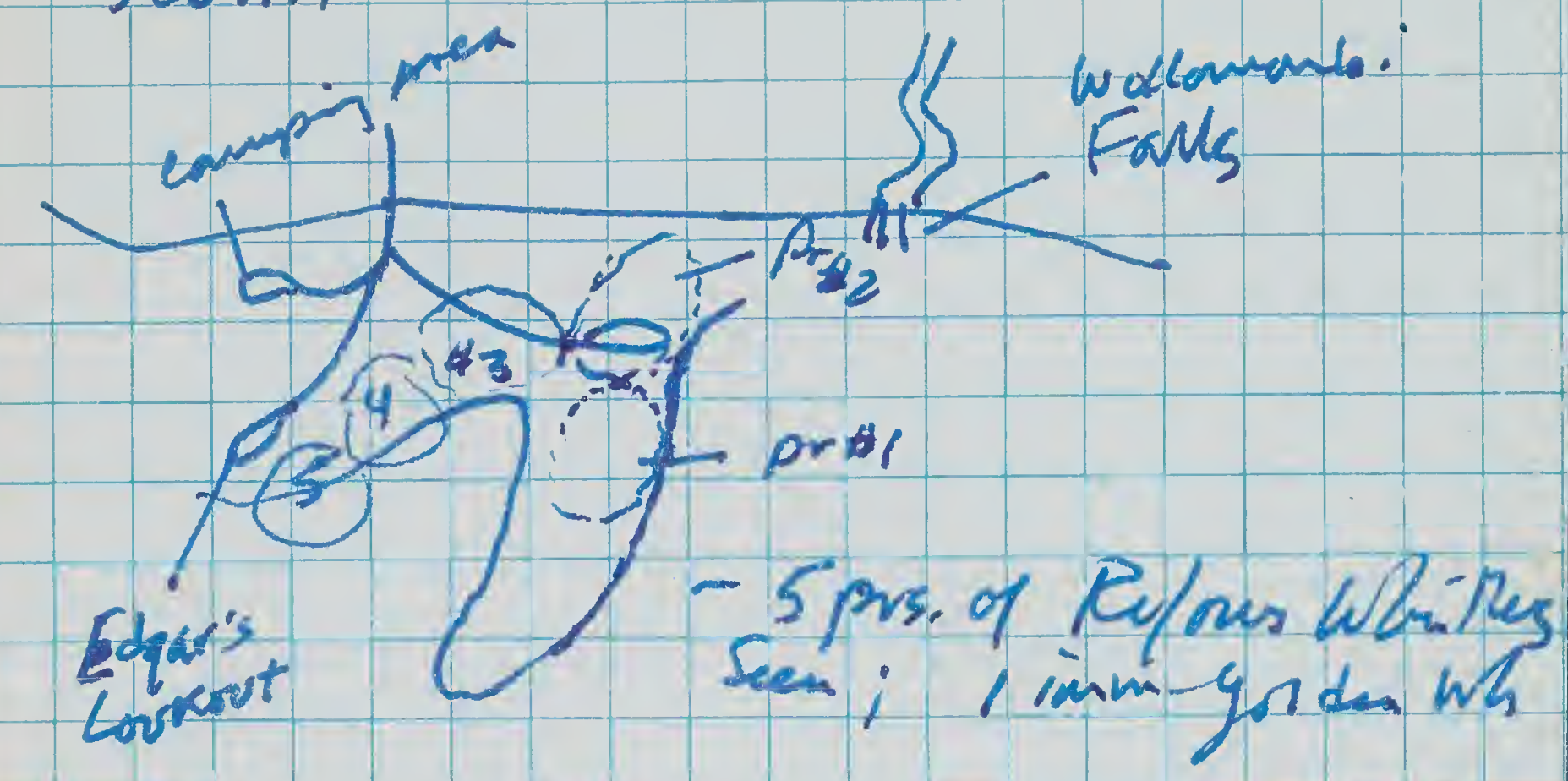

Lots of Leadeu Fe; ds - ser. Worga Pigerns, provf spoted Quavil Thumeshes - vely

dove like cin gewerd sacipu and worke of wrekey, vather than zuoppy. Strorgh

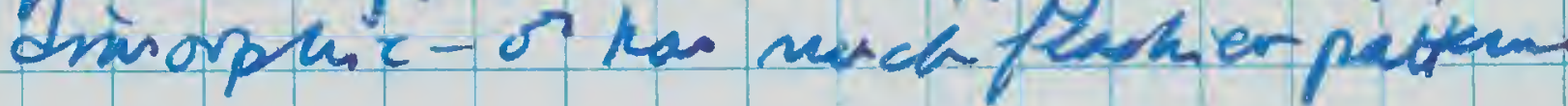

Sev.prs. I Saued kinghisher (ove vest forend)

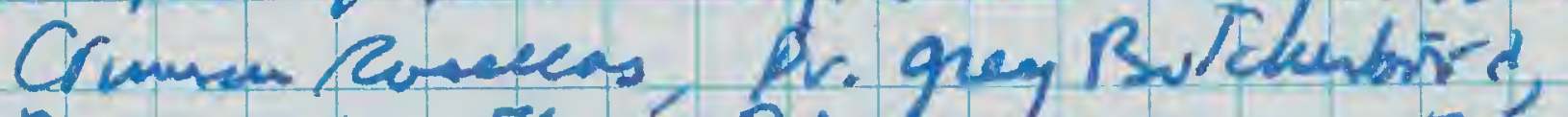

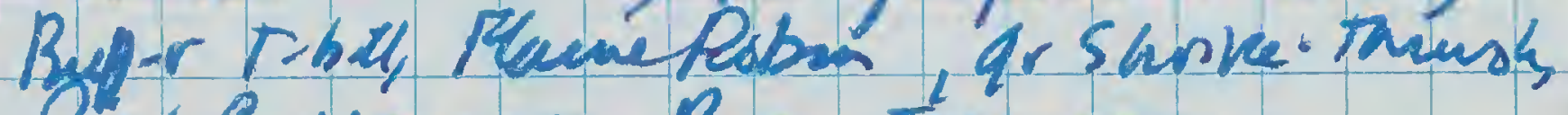
Pied Curvarory, Prom Treecrepu, Wh-Ta Treecleper, V. SitTella, Magpe Austr. Raven

904 Th.p to NenEykad Nar.Pask 58753.3

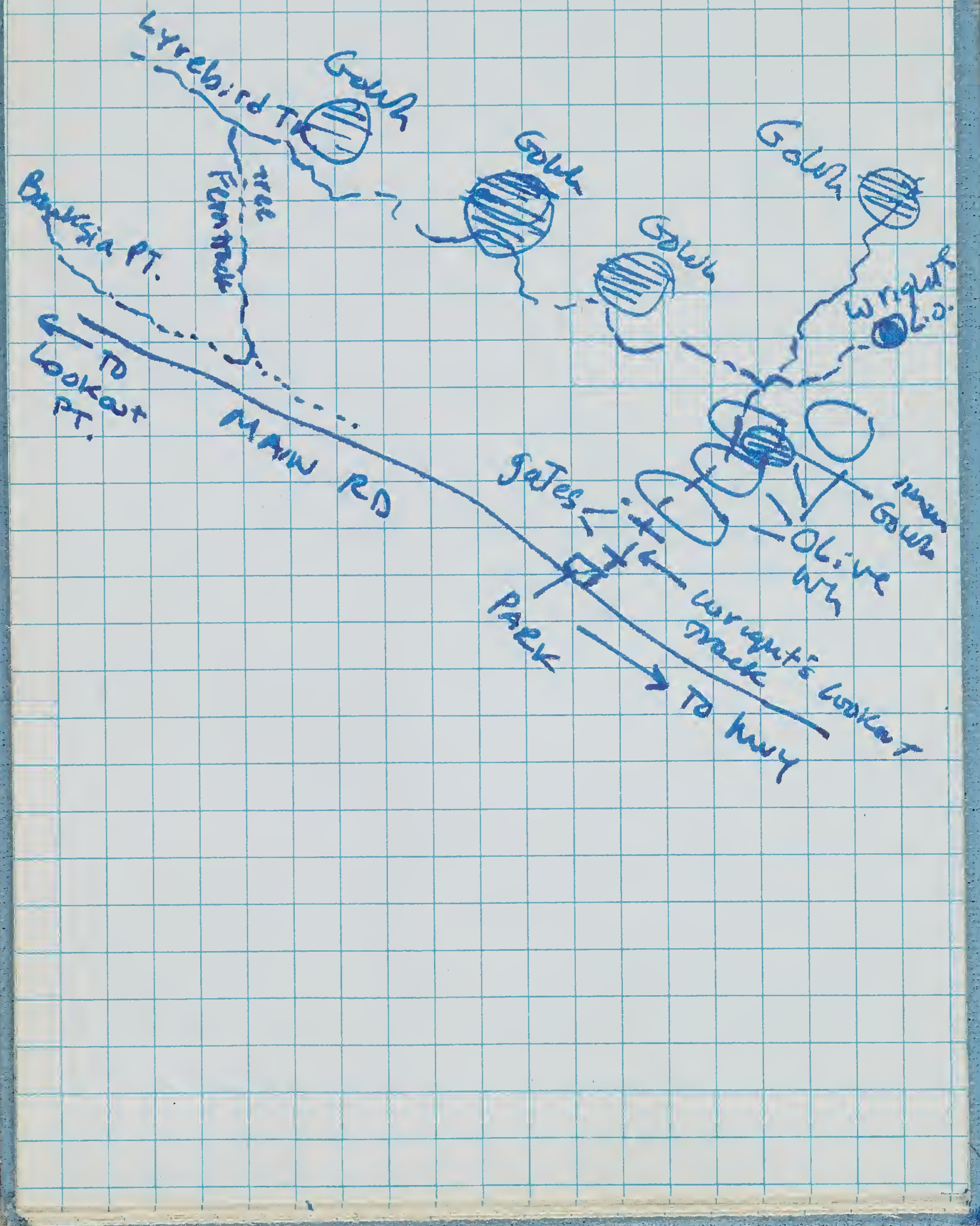


IID d. Tr.p ro Grafton-Dorrigo Area

Cion Aan Cean, Ceen, are (la on windishelo) 9033.4

$170.2 \operatorname{soc}{ }_{1}$ DorngoN.P ar. Neva-neva Picue Arem.

172.7 Neverdrarer Diunic Area $09: 50$

186 Dirrgo

$120 \mathrm{~T}$. Senimar at U.N.E.

130 CT Dumaras Daw 6:30

Tuearear clecer Lalun, mild

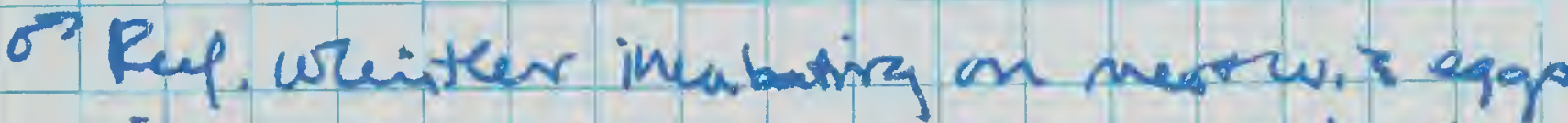
in. pine tree drst. N. pas ki arre wo bout ramp. rest $\approx 2$. Sim above gpound wu. Aun of piñe bough.

Is ou Dorriato trip 5.50 9350.2 sjant

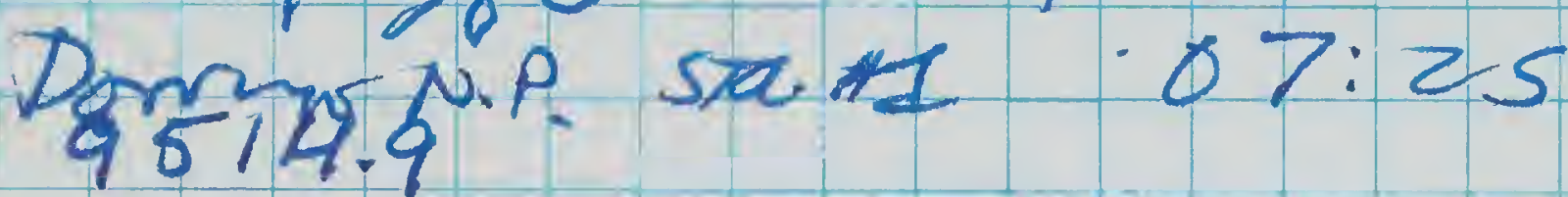

Aurv-Nour Pruiv 4517.6

lv. 13iro

16 OCT

Misculqate Rd. - N. of BundarraRd. V. open gralsnverge w. seattered Acacias a rass for us $0.5 \mathrm{~km}$ The min tae quars to $20-25 \mathrm{~m}$ 4. RT.bill, Sonlark,

Gudusty of Hew Turn, Mawna gum Saplings Treemartin, Mudlark, pr. Goldfinch qelah, S. Rosely. Red-vumpes Parrit,

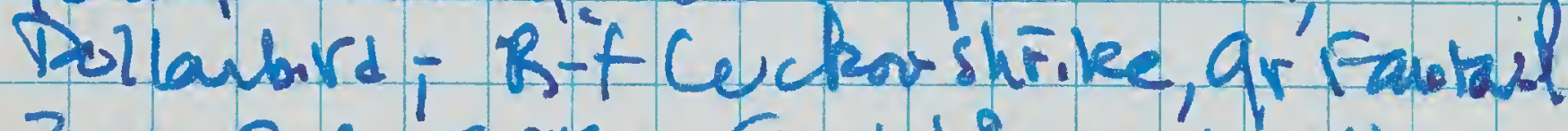
2 pr. Pus waiter, Guted is an (wat) Red clattebird (ment), Y-R r.b!ll (Mest), Bhewren, Noiry unei (w. Resglins), Maypie Cu.bidgli striein sriated Pandíte, Wh-The wdrber, WWTillex, qold.B.Cúckor, 
N-S Conider rumy so I MT. Mitcheed S. If Bundarva Rs -

rathe doune rows of smiqy bonk, gum Arqupleva. Not as much us as lst ore, but sove sapeings and Cratages

Mithehrelord, Kerkaburra Y-FHE, Wh-wapud the Sithelea sew pr. Ref Whistlers, Puscom HE, Res wathebird, N. Friarbird, Y-RT.b:ll, Wh. Tun Warbler, Ruf-Sorglante, Dusky Wodsw, B-F Auckoostrike. Ereoted Pigeon, Naim Miner, Daturc, striefad T-bill.

7

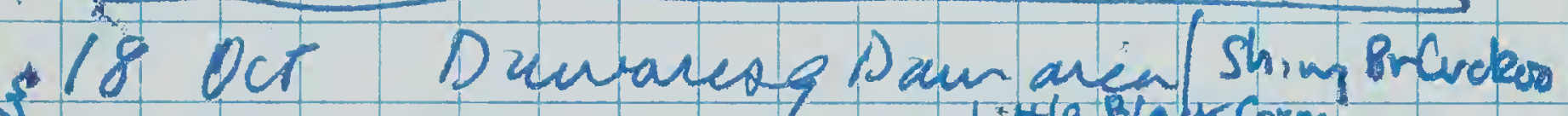

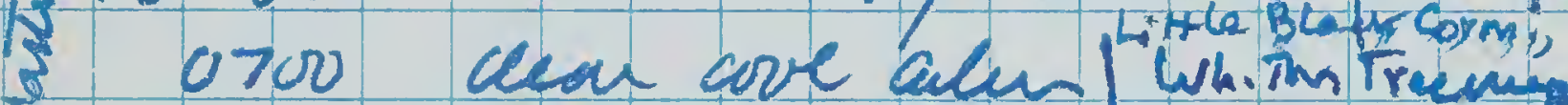

saued KE Pled Canrown watriller, Shrike-tet

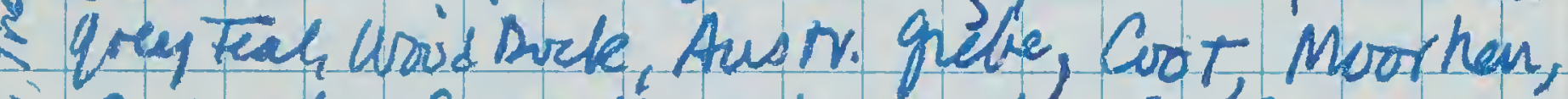

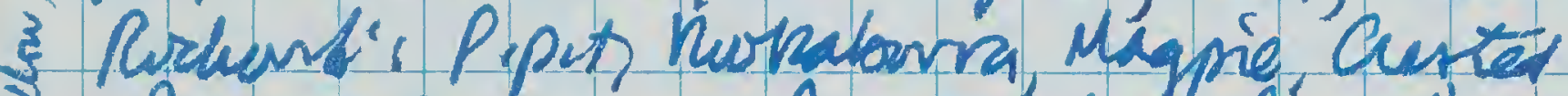
- Ryen, Red-neupedBavot, Whiti faced Heren, - Gilah pustr. Reed-wables, susto Raven

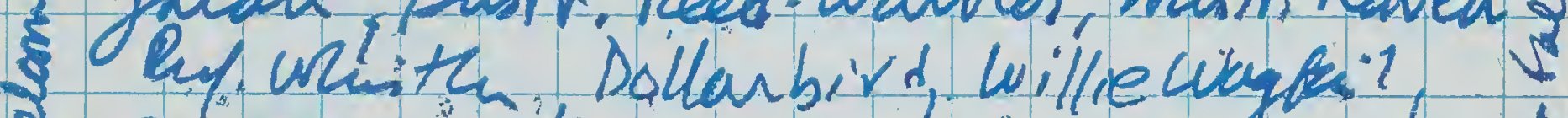

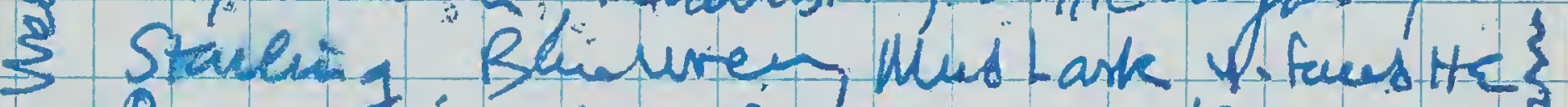
Ruple tiramben Blacle Durk, smi. Pardabte, of

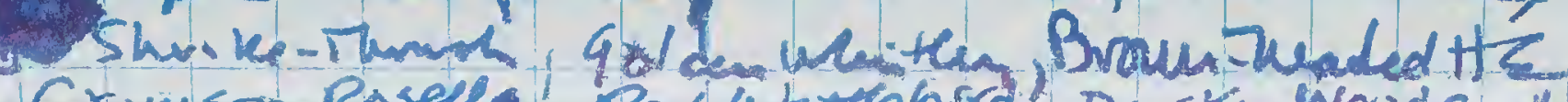

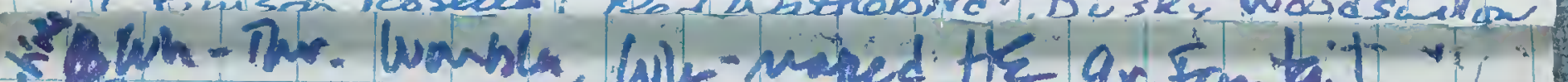

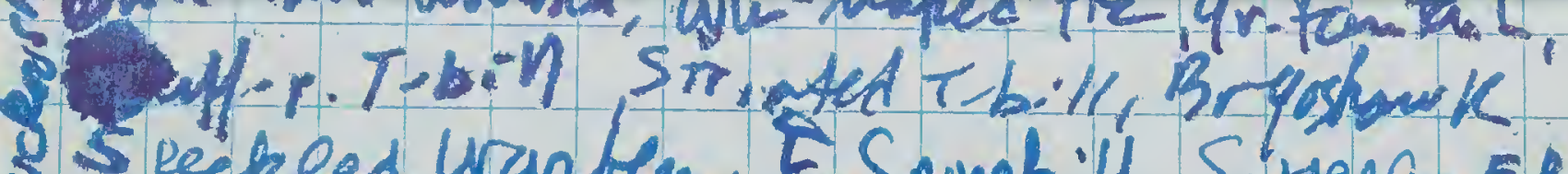

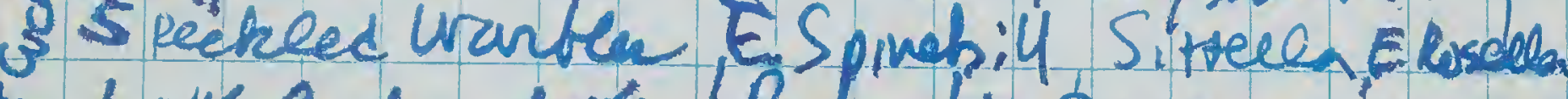

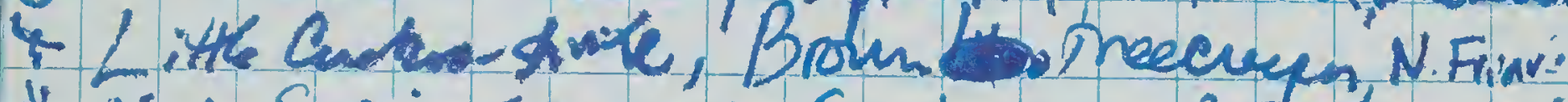
it bire, Satin FC, Wh-br Scombwren, BrT. bill tosk sund plubes of \& kep urai tes on nest ( 3 eqs) ar. partij area

Silvertop Sringy buk (E, Laevopinea)

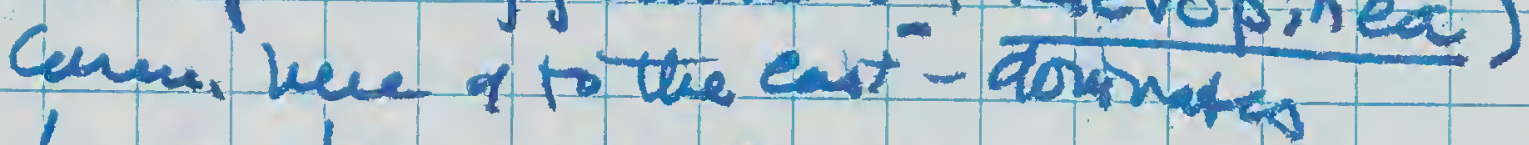

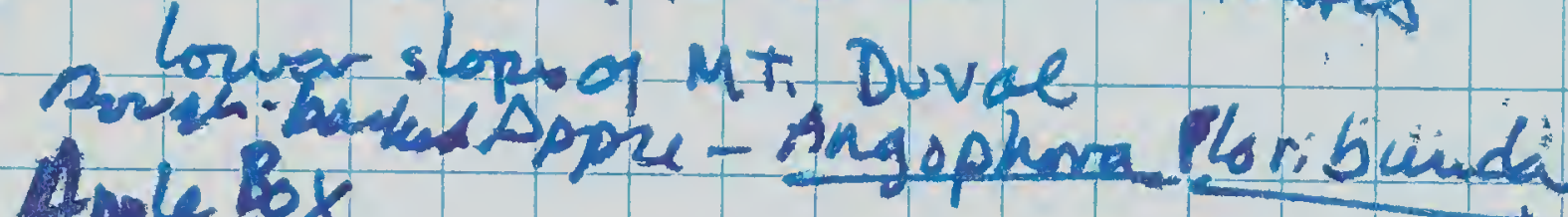
Aple Box Mountain gun E. dalrquplearua) (reaneren Mauna gam)

(2 plotos taken of This vosdeanb-

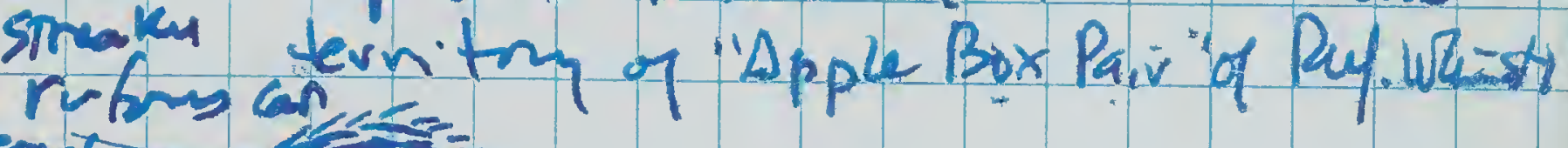
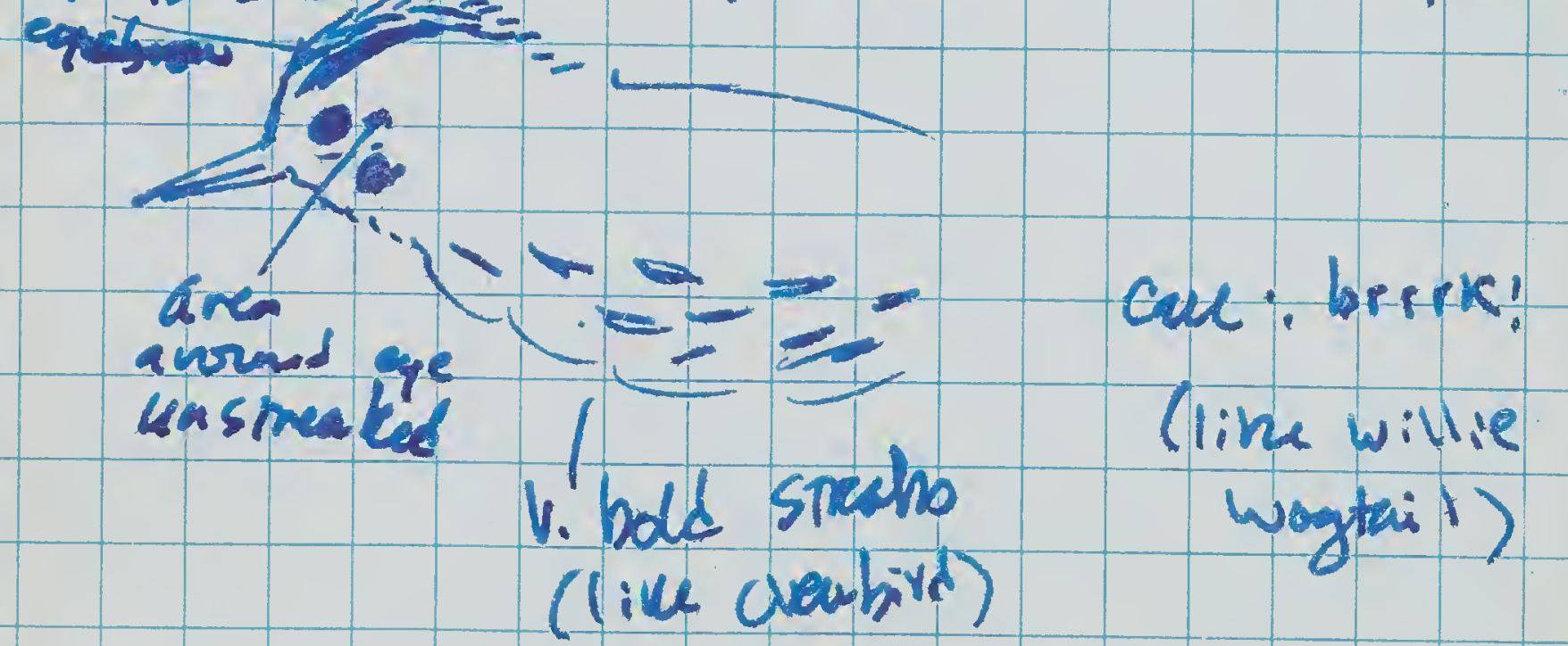


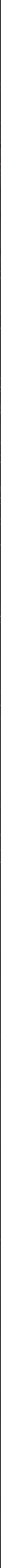




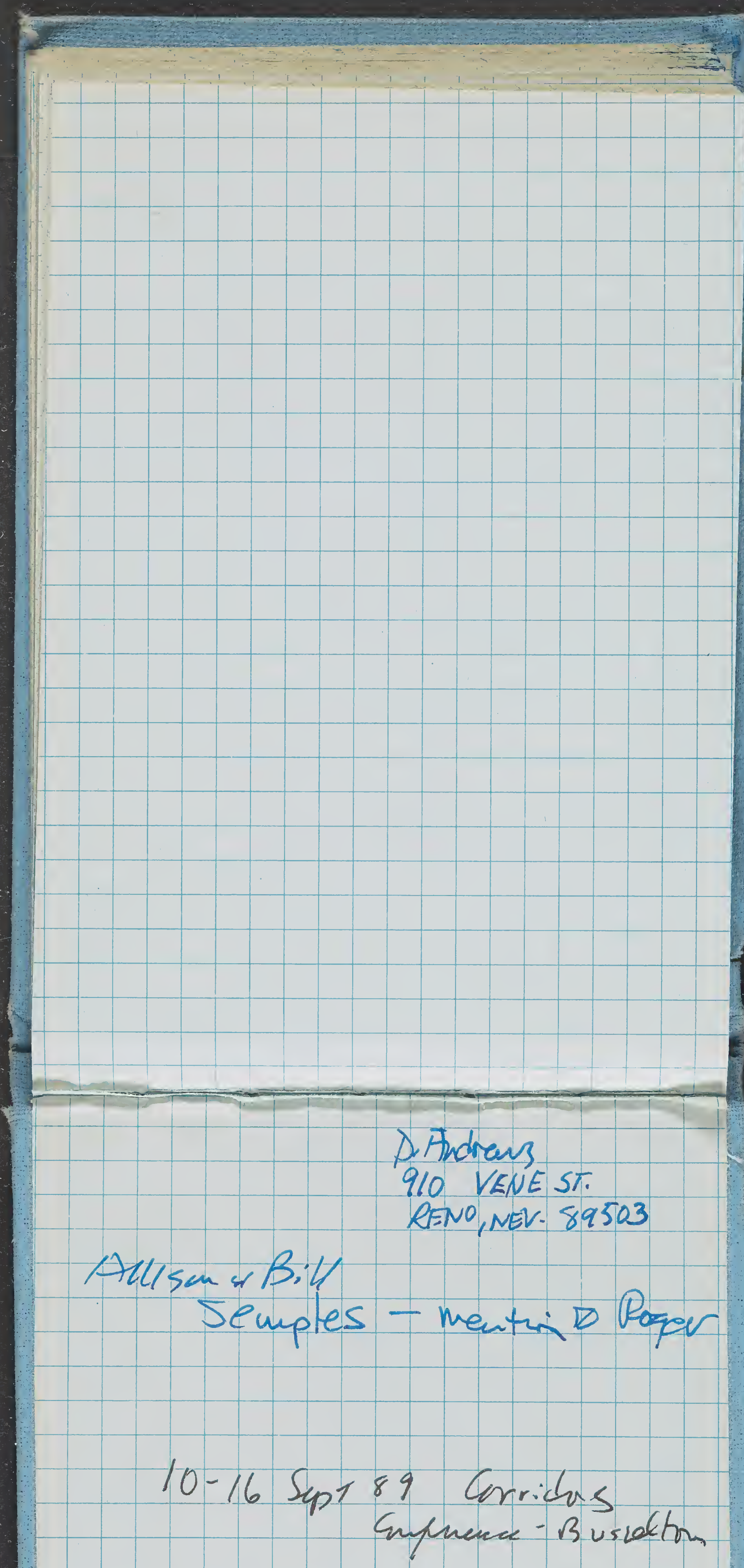




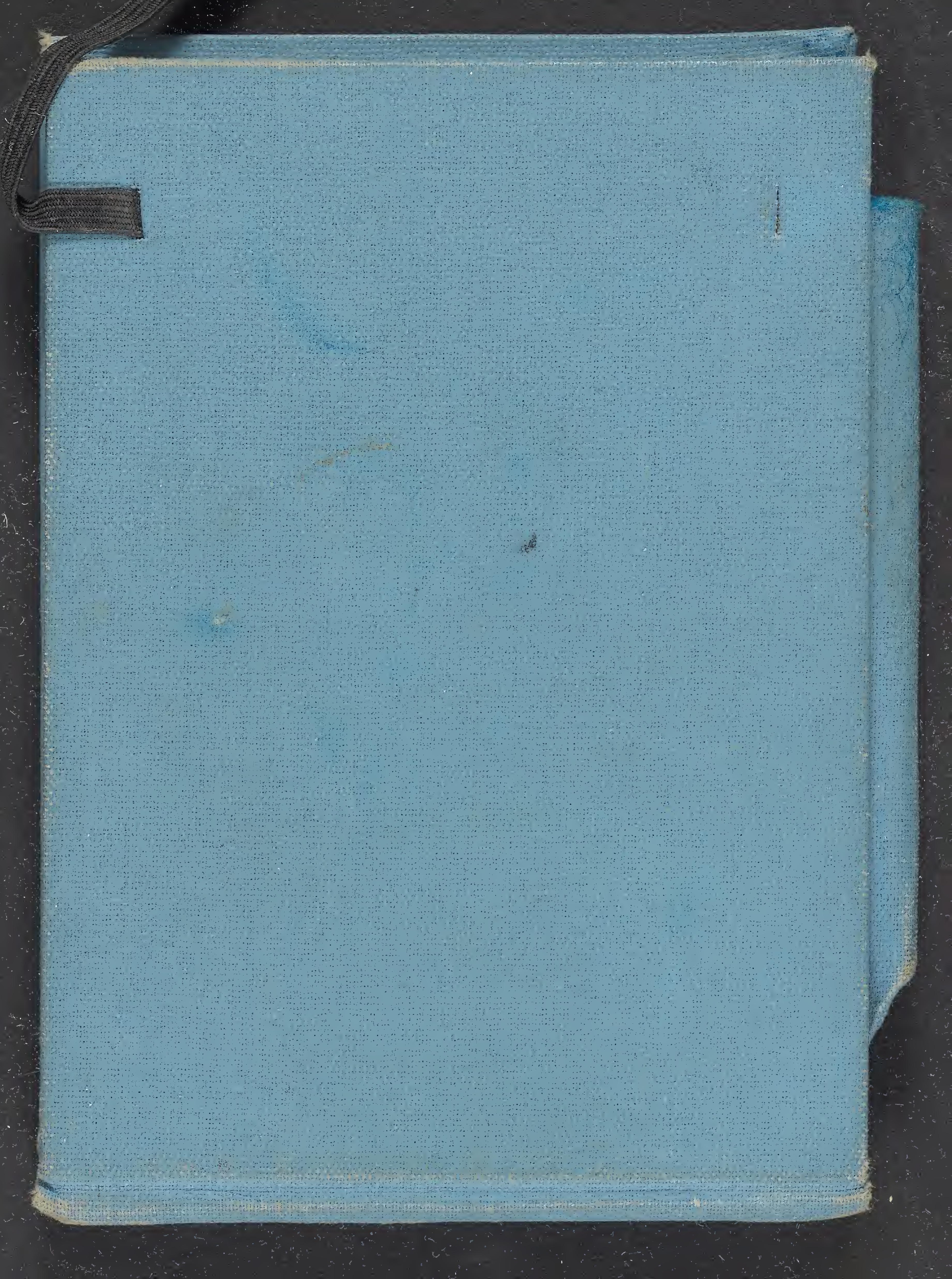

